San Jose State University

SJSU ScholarWorks

Master's Theses

Master's Theses and Graduate Research

1991

\title{
The cultural and intellectual origins of Emma Williard's educational philosophy
}

Diane Claire Wood

San Jose State University

Follow this and additional works at: https://scholarworks.sjsu.edu/etd_theses

\section{Recommended Citation}

Wood, Diane Claire, "The cultural and intellectual origins of Emma Williard's educational philosophy" (1991). Master's Theses. 87. DOI: https://doi.org/10.31979/etd.smnd-8gnc https://scholarworks.sjsu.edu/etd_theses/87

This Thesis is brought to you for free and open access by the Master's Theses and Graduate Research at SJSU ScholarWorks. It has been accepted for inclusion in Master's Theses by an authorized administrator of SJSU ScholarWorks. For more information, please contact scholarworks@sjsu.edu. 


\section{INFORMATION TO USERS}

This manuscript has been reproduced from the microfilm master. UMI films the text directly from the original or copy submitted. Thus, some thesis and dissertation copies are in typewriter face, while others may be from any type of computer printer.

The quality of this reproduction is dependent upon the quality of the copy submitted. Broken or indistinct print, colored or poor quality illustrations and photographs, print bleedthrough, substandard margins, and improper alignment can adversely affect reproduction.

In the unlikely event that the author did not send UMI a complete manuscript and there are missing pages, these will be noted. Also, if unauthorized copyright material had to be removed, a note will indicate the deletion.

Oversize materials (e.g., maps, drawings, charts) are reproduced by sectioning the original, beginning at the upper left-hand corner and continuing from left to right in equal sections with small overlaps. Each original is also photographed in one exposure and is included in reduced form at the back of the book.

Photographs included in the original manuscript have been reproduced xerographically in this copy. Higher quality $6 "$ x 9 " black and white photographic prints are available for any. photographs or illustrations appearing in this copy for an additional charge. Contact UMI directly to order.

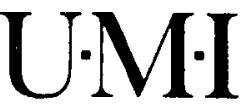

University Microfilms International

A Bell \& Howell Information Company

300 North Zeeb Road. Ann Arbor. MI 48106-1346 USA

$313 / 761-4700 \quad 800 / 521-0600$ 
The cultural and intellectual origins of Emma Willard's educational philosophy

Wood, Diane Claire, M.A.

San Jose State University, 1991 
THE CULTURAL AND INTELLECTUAL ORIGINS OF EMMA WILLARD'S EDUCATIONAL PHILOSOPHY

\author{
A Thesis \\ Presented to \\ The Faculty of the Department of History \\ San Jose State University \\ In Partial Fulfillment \\ of the Requirements for the Degree \\ Master of Arts
}

By

Diane Claire Wood

August, 1991 

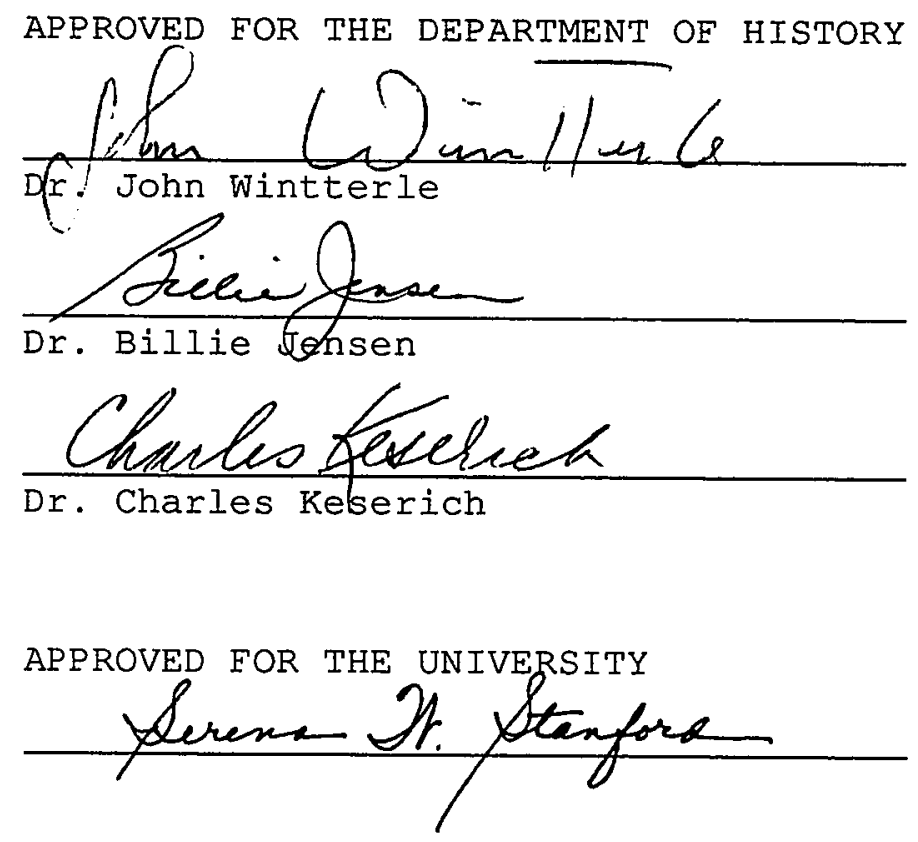


\section{ABSTRACT \\ THE CULTURAL AND INTELLECTUAL ORIGINS OF EMMA WILLARD'S EDUCATIONAL PHILOSOPHY}

by Diane Claire Wood

The Troy Female Seminary, founded in 1821 in Troy, New

York, was one of the first major female educational

institutions of higher learning for women in the United

States. Still in operation today as the Emma Willard School, it is a monument to the vision, hard work, and determination of its founder Emma Hart Willard.

As a pioneer of women's education, willard has been the subject of both biographical and feminist scholarship. The primary purpose of this study is to present a detailed body of evidence which traces the major cultural and intellectual foundations of Emma Willard's educational philosophy as reflected in her writings on education. Willard's thoughts on the role of women, the virtue of democracy, and the function of religion, provide a backdrop for the historical analysis of late eighteenth and early nineteenth century American culture and society. The thesis includes a wide range of both primary and secondary source material, as well as an extensive bibliography. 


\section{ACKNOWLEDGEMENTS}

Many people must be thanked for their assistance, help and encouragement in making this thesis possible. At San Jose State University, I would like to express my gratitude to the members of my graduate advisory committee, Drs. John Wintterle, Billie Jensen, and Charles Keserich for their careful comments and their support throughout the entire process. My thanks also goes to Professor Irma Eichhorn who first inspired me to focus my attention on the history of women's education.

A special note of appreciation goes to Hjordis Madsen, Cathy Perez and the staff of the Interlibrary Loan Department at San Jose State University Library for their unflagging persistence in tracking down and obtaining the various sources which I requested. My thanks to Vanetia Johnston who spent long hours editing, typing and retyping this manuscript. Finally, a heartfelt "thank you" goes to the staff in the office of the History Department, San Jose State University, for lending a sympathetic ear when it was sorely needed.

At the Emma Willard School in Troy, New York, I would especially like to thank Barbara Wiley and the staff of the school Library and Archives for their gracious hospitality when I visited. Without Barbara's unfailing good humor and 
genius in locating materials, I would not have found much of the information in this thesis. Her prompt answers to my frantic telephone calls were very much appreciated. I would also like to thank Dr. Lucy Townsend of Northern Illinois University at DeKalb, for her encouragement and advice. Finally, I would be amiss if I did not acknowledge the support of my friends; in particular, Carole Mauss, Jeanne Mager and Gail Smallwood. For their constant belief in my ability, I am grateful. Thanks to all of you, I can now say "It is finished." 
To

my husband, Jim,

whose love and support made it all possible

and

Dr. John Wintterle

who showed me the beauty of

words well written 
TABLE OF CONTENTS

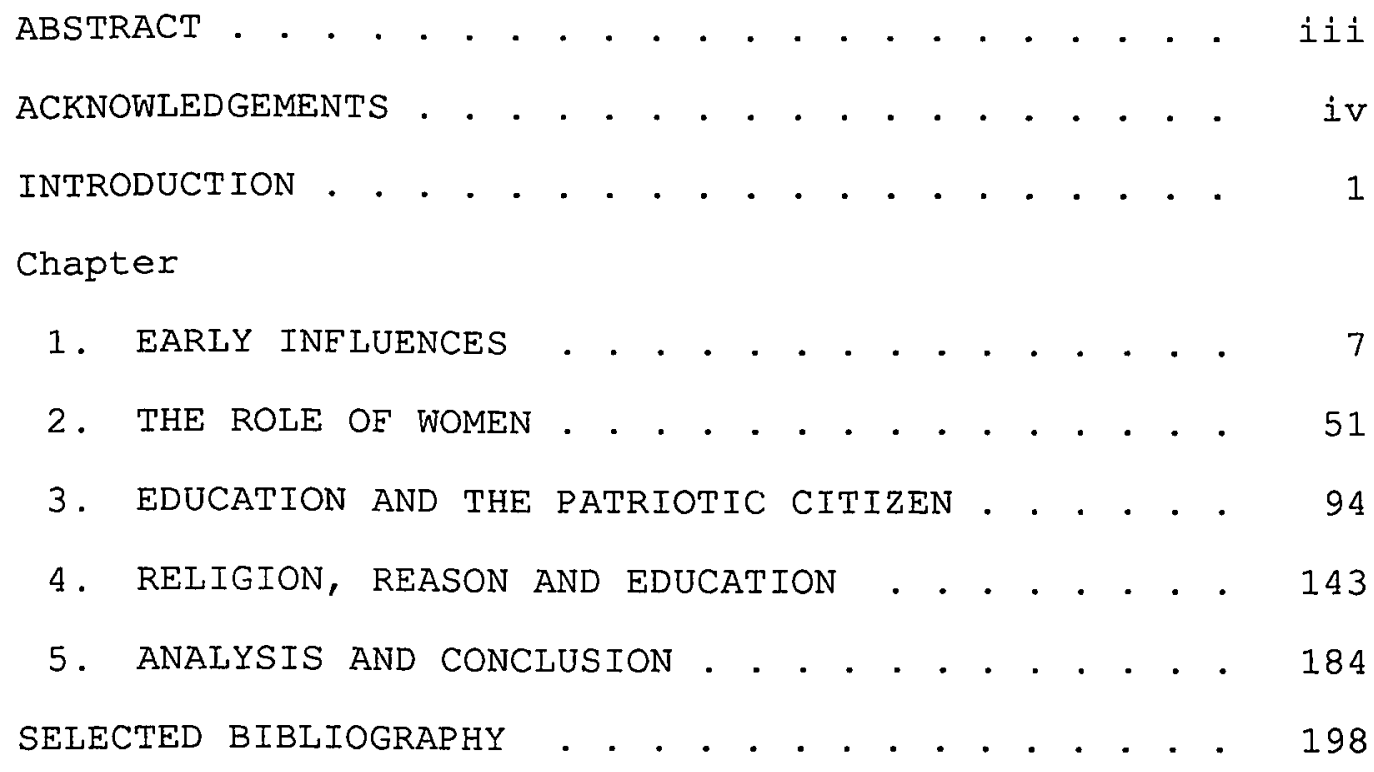




\section{INTRODUCTION}

The Troy Female Seminary, founded in 1821 in Troy, New York, was one of the first major educational institutions of higher learning for women in the United States. During its one hundred and seventy five year history the school has educated thousands of young women, instituted a highly challenging academic curriculum, and established a national reputation. Still operating today as the Emma Willard School, it is a monument to the vision, hard work, and determination of its founder Emma Hart Willard.

Willard's first public efforts on behalf of educational reform began with the publication of her plan for Improving Female Education presented to the New York Legislature and the public in 1819.1 In this document Emma willard incorporated ideas which were to make her a national figure, earn her respect of her peers, and the gratitude of generations of young women. There is little doubt that Emma Willard intended the Plan to be the beginning of her life's work.

lEmma Willard, An Address to the Public: Particularly to the Members of the Legislature of New York, Proposing a Plan for Improving Female Education (Middlebury: J. W. Copeland, 1819). 
While Willard did not succeed in convincing the New York Legislature to allocate public funds for the establishment of a permanent educational institution for women that day in 1821, her Troy Female Seminary became a model for other schools of this type throughout the country. Through her actions and writings, Emma Willard has rightfully earned her place as one of the most influential educational reformers of the early nineteenth century.

Another, equally valuable way of viewing willard's writings on education is as a statement of her underlying educational philosophy. Within the pages of her Plan, as well as her other written works, the careful reader finds ample evidence of Willard's deeply held beliefs concerning the purposes of education, the role of the educated citizen in society, and the proper ordering of the universe. In her efforts to bring about a change in the inequities which existed between male and female education, Emma Willard's writings on education tell us much about the mind of early nineteenth century America.

Previous scholarship on Emma Willard has tended to fall into two major categories: biographical or feminist. Biographical accounts of Willard's life, such as Alma Lutz's seminal work, Emma Willard, Daughter of Democracy written in 1929, have provided researchers with standard, somewhat 
laudatory descriptions of Willard's accomplishments. ${ }^{2}$ Later efforts on behalf of women's history have attempted to reinterpret willard's life in terms of modern feminism. 3

Both types of research have focused primarily upon the uniqueness of Emma Willard's actions in the field of education--those ways in which she was different from her contemporaries. But these essential differences were only a part of Emma Willard. Of equal importance are the ways in which Willard's writings on education reflect the various ideological currents of main stream nineteenth century America--those underlying principles upon which the country depended for its stability and progress.

Like a vast majority of her countrymen, willard's values were progressive, not radical; innovative, not revolutionary. To date, however, no studies have been made which explore Emma Willard's philosophy of education as part of an evolutionary intellectual continuum. Such a study is warranted as it will tell us much about America's cultural history during this formative period.

The primary purpose of this study is to present a detailed body of evidence which traces the major cultural and

\footnotetext{
2 Alma Lutz, Emma Willard, Daughter of Democracy (Boston: Houghton Mifflin, 1929).

${ }^{3}$ See in particular Anne Firor Scott, "What, Then, is the American: This New Woman?" Journal of American History 65 (December 1978): 679-703.
} 
intellectual foundations of Emma Willard's educational philosophy as reflected in her writings on education. Further, this study makes the case that, while Willard's actions on behalf of women's education were innovative, her thoughts on education were far more representative of nineteenth century America's philosophical heritage than either laudatory biography or feminist revisionism has yet shown.

The truly representative nature of Willard's educational philosophy is derived from the three main assumptions upon which it rested. These three assumption were as follows: that women as rational creatures were the natural and most desirable teachers of young children; that the future of American democracy rested upon an educated, virtuous citizenry; and that the purpose of education was to provide a Christian foundation for society.

In these assumptions, Willard's writings on education reflect the influence of her own personal teaching experiences, the New England Puritan environment in which she was raised, and the scholastic tradition of the European Enlightenment in which she studied. Inferential evidence shows that these influences began early in Willard's life. Her later writings prove that, while modified over time, her core beliefs remained intact throughout the rest of her long career. 
A love of learning and scholarship came naturally to Emma Willard. Her parents, Lydia and Samuel Hart, provided a family atmosphere in which literature and politics made up everyday conversation between parent and child. It has been noted that willard's relationship with her father was particularly close.

It was Willard's male mentors who were to play the largest part in stimulating her intellectual growth and supporting her earliest scholastic efforts. First her father, and later her husband and her professional associates, all listened to her ideas and provided direction or advice. Unlike most young women of her era, Emma Willard did not lack for early educational encouragement. Religion was another early influence upon her intellectual growth. There is ample evidence that Emma Willard grew up with a firm, but not dogmatic, religious outlook. Her Puritan, New England heritage provided her with a belief in the divine purpose of scholarship. Willard never questioned the fact that the work she accomplished was done for the glory of God and for the betterment of society. Her writings on education reflected her religious convictions. Patriotism provided another early influence upon the development of Emma Willard's educational philosophy. From Samuel Hart's stories about America's early history, Willard formed the belief that America was the promised land and that 
democracy was the best of all forms of government. Like her contemporaries, Willard also came to believe that

preservation of the young republic required an educated

citizenry.

Finally, Emma Willard embraced a tenet of the European Enlightenment; namely, that women, as well as men, could be educated to think rationally. Reason became the standard by which she and most of her contemporaries measured the progress of society. Her educational efforts were largely pointed toward the development of a scientific, well-reasoned school curriculum.

In her struggle to improve female education in this country, Emma Willard stands as a pioneer. As a representative of her generation, her writings on education provide a backdrop for a historical analysis of the major intellectual and cultural foundations of late eighteenth and early nineteenth century America. 


\section{CHAPTER ONE \\ EMMA WILLARD'S EDUCATIONAL PHILOSOPHY: \\ EARLY INFLUENCES}

Emma Willard's personality and her early sense of her own special destiny were essential to what she was to accomplish in her lifetime. Her belief in the cause of women's education later became absolute and rarely did she doubt for a minute that she had been chosen by God for one purpose. "I believe (I speak it with solemnity), God has specially called me to labor. . . "l she was later to tell an audience.

That Emma Willard was an unusually bright young lady, there can be little doubt. The basic components of a unique personality were evident early in her life. Even allowing for a certain "rewriting" of history after the event, willard appears to have been an extraordinary young woman. There is no lack of biographical testimony confirming this fact. Her unusual drive, enthusiasm, ambition and ability are well documented.

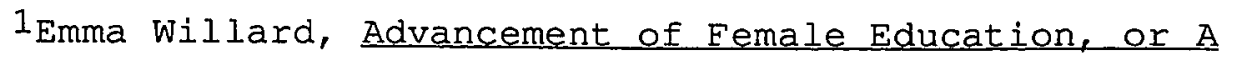
Series of Addresses in Favor of Establishing at Athens, in Greece, a Female Seminary, Especially Designed to Instruct Eemale Teachers (Troy: Norman Tuttle, 1833), 5.
} 
Emma Willard accomplished a great deal in her efforts to improve female education in the United States. She established educational institutions for women, improved educational institutions for women, improved female curriculum, gave speeches, wrote letters, and lobbied government or private agencies for further funding. Aside from her outward successes, however, questions about her inner motivation remain unanswered. What made her different? Why did she feel this sense of destiny? What drove her on? The answer lies partially in a personal philosophy that took her beyond woman's ordinary sphere, one which set her life on a different course. It was a philosophy that contained a personal interpretation of the role of women, the function of education in society and the proper order of the universe.

There were three early influences upon the development of Emma Willard's educational philosophy. The first influence was a world perspective provided by her Puritan, New England ancestry. The social, economic and cultural environment of her childhood supplied her with a particular set of core values. Using these values as basic building blocks, she was to construct an outlook on life all her own. The second major influence was the intellectual relationships she formed with certain men in her life; especially important were her relationships with her father, 
Samuel Hart and her husband, Dr. John Willard. Throughout her career Emma Willard would take counsel from these male mentors. Often, particularly at the beginning of her efforts, she was heavily influenced by their perspectives on life.

Finally, Willard's educational philosophy was shaped to some degree by her initial experiences as a student and young teacher. These early experiences laid the foundations for what would become her own brand of pedagogy.

The extent to which these three influences had an impact on the development of Willard's later thought is clearly visible in the first thirty years of her life. The culmination of her early efforts came with the publication in 1819 of her first major written work: An Address to the Public: Particularly to the Members of the Legislature of New York, Proposing a Plan for Improving Female Education. 2 While Emma Willard and almost everyone else saw this document as a practical method for improving women's education, the Plan was also the philosophical result of these three major formative influences. This chapter will be devoted to an examination of Willard's early years. It will

2Emma Willard, An Address to the Public; Particularly to the Members of the Legislature of New York, Proposing a Plan for Improving Female Education (Middlebury: J.W. Copeland, 1819). 
focus on the influential factors that created the foundation for her later philosophical efforts.

\section{Background}

The moon was hidden behind dark clouds, and the rain fell gently as two small girls made their way toward an old, forsaken dwelling house located on Lower Lane, just as it turned eastward. There were stories going around town that the house was haunted and that mysterious lights had been seen there at midnight. Creeping along, disguised in dark clothing to avoid detection, Emma Hart and her friend had decided to investigate.

It was typical of Emma Hart that she would be motivated to discover the truth behind the rumors. Intensely curious, undaunted by a challenge, Hart was not one to be scared by ghosts, or anything else for that matter. So off the two girls went to discover the source of the mystery. They were sure that a logical explanation could be found for the strange occurrences. All they needed to do was to investigate. 3

${ }^{3}$ The denouement of Emma Willard's adventure was not very exciting, "as the two girls crept cautiously up to the window and looked in they saw--a company of men playing cards." Quoted in Catharine M. North, History of Berlin, Connecticut, rearranged and edited with Forward by Adolph Burnett Benson (New Haven: The Tuttle, Morehouse and Taylor Company, 1916), $70-71$. 
Throughout her life Willard was to hold fast to her belief in knowledge and truth as weapons against the unknown.4 In later years that same little girl would challenge new "ghosts"; the ghosts of bigotry and prejudice which permeated much of nineteenth century thinking about the intellectual abilities of women. Her campaign for the improvement of women's education would be marked with the same courage and determination that she had displayed as a young girl.

It was not unusual for her to accept a challenge by meeting it head on. She came from a background that nurtured a pioneering spirit and a courageous attitude toward life. During her career this same courage stood her in good stead, supporting her efforts on behalf of women's education and sustaining her through occasional nights of self doubt. When she died she would be called "one of the great educators of the day"; 5 "preeminently a REPRESENTATIVE WOMAN, who suitably

${ }^{4}$ When asked in 1837 to write a series of addresses for children in order to "give them good advice," Emma Willard selected "Wisdom" and "Truth" as the topics of the first two addresses. Those addresses were later expanded into a book on morals for young people. In the Introduction to that book Emma Willard was to assert that, "The subject chosen for my second address was "TRUTH," which, next to Wisdom, is the greatest word in Morals, and without which Wisdom cannot exist." Emma Willard, Morals for the Young; or, Good Principles Instilling Wisdom (New York: A.S. Barnes and Co., 1857), 11.

5 Mrs. John H. Willard, "A Memorial of the Late Mrs. Emma Willard," in Proceedings of the Seventh Anniversary of the 
typifies the great movement of the nineteenth century for the elevation of woman." 6

During her long life, Emma Willard traveled many miles from the small farmhouse that was her early home. Along the way she gained wealth, prestige and influence far beyond anything she could have imagined, but as her later writings reveal, throughout it all she never lost sight of the central values that her early upbringing provided.

Foremost among these values were a strong belief in America and all that it stood for, a determination to fulfill what she saw as women's natural destiny, a reverence for education and learning; and a deep and abiding religious faith.

\section{Beginnings}

Emma Hart was born on February 23, 1787 in the Worthington Parish of Berlin, Connecticut, just down the way from the "haunted house" on Lower Lane which she was to investigate so bravely as a young child. Early American families tended to be quite large, and Emma Hart's was no

University Convocation of the State of New York, August 2-4, 1870 (Albany: The Argus Company Printers, 1871), 73.

6 Henry Fowler, "The Educational Services of Mrs. Emma Willard," in Memoirs of Teachers, Educators, and Promoters and Benefactors of Education, Literature and Science, ed. Henry Barnard (New York: F. C. Brownell, 1861; reprint New York: Arno Press and the New York Times, 1969), 167 (page references are to reprint edition). 
exception. She was the sixteenth child in a family of seventeen children. Her younger sister, Almira, born five years later, was the seventeenth and last Hart child.7 Thirteen of the seventeen children reached maturity. Her father, Captain Samuel Hart, who was born on January 21, 1738, married Rebecca Norton, a girl of eighteen, on October 10, 1757. Rebecca and Samuel Hart had seven children, of whom six survived. When Rebecca Hart died in July of 1769, the widower, who was left with six children to care for, wasted no time in proposing to Emma Hart's future mother.

Samuel Hart and twenty-three year old Lydia Hinsdale were married on October 4, 1770. Together Lydia and Samuel had ten more children; Emma was the ninth. 8 when speaking of Emma's birth, her father told the pastor, "If baby had been a boy, we would have named him for General Washington, but under the circumstances she will be baptized as Emma." The

${ }^{7}$ It is interesting to note that Emma Willard's sister, Almira Hart Iincoln Phelps, also became a distinguished Phelps: Her Life and Work Lydia Bolzau, Almira Lincoln Printing Co., 1936). 8 A very detailed account of the Hart family can be found
in Catharine M. North, History of Berlin, Connecticut, $60-79$. 
Pastor responded, "The feminine form of Emmanuel, which signifies 'God with us'."9

Emma Hart's roots went deep into the rocky soil of New

England. All her life she was to have a deep and fundamental pride in her family's history and her position in society. Two of her ancestors, Thomas Hooker, a minister in the Church of England, and Stephen Hart, the American progenitor of her father's family, had sailed from England in the first quarter of the seventeenth century in search of religious freedom. In 1636, these two men led a group of about one hundred settlers into the Connecticut Valley, where they founded the towns of Hartford and Farmington. 10

Emma Hart's mother's family, the Hinsdales, were descended from Robert Hinsdale who settled in Dedham, Massachusetts in 1637. Thirty years later he became one of

${ }^{9}$ Quoted in Alma Lutz, Emma Willard; Pioneer Educator of American Women (Boston: Beacon Press, 1964), 2.

10Emma Willard's ancestor, Thomas Hooker is variously referred to as "one of the founders of Connecticut," and "an original proprietor of the town of Hartford, Connecticut, and later a pioneer settler of Farmington, Connecticut." An even-handed treatment of Emma Willard's family background is given in Alma Lutz, Emma Willard, Daughter of Democracy (Boston: Houghton Mifflin, 1929), chapter 1. For a much more typical description of Emma Willard see the entry entitled "Emma Willard" in Sarah Josepha Hale, Women's Record or Sketches of All Distinguished women from Creation to A.D. 1854: Arranged in Four Eras with Selections from Female Writers of Every Age (New York: Harper and Bros., 1855; reprint, New York: Source Book Press, 1970), 816-17 (page references are to reprint edition). 
the original proprietors of Deerfield, Massachusetts. Emma Hart was, as one admiring biographer put it, ". . of pure English blood, of the good old Puritan stock."11

Emma Hart's mother was herself an extraordinary woman. Apart from raising a brood of sixteen children, Lydia Hart performed the arduous tasks of running an eighteenth century household. Aside from her domestic abilities, Mrs. Hart's personality incorporated many of the standard Puritan values such as thrift, economy, and industry.

Written accounts of Lydia Hart's life also attest to the fact that she was quite a well educated woman, even for those times. The following recitation is a typical description of Emma Hart's mother:

She was practical, quietly executive, severely but unwaveringly industrious; and although well educated for her day, and tenderly reared, and in excelling in all the delicate fabrics of the needle, she had in full perfection the New England trait of making much out of little, a little out of nothing. She had the true economy, not of selfish hoarding, but of industriously producing, carefully preserving and wisely distributing. 12

Observing the example her mother set, Emma Hart learned the value of hard work, the meaning of generosity, and the joys and tribulations of a solid family life. Lydia Hinsdale was the central, bonding force which held the Hart family

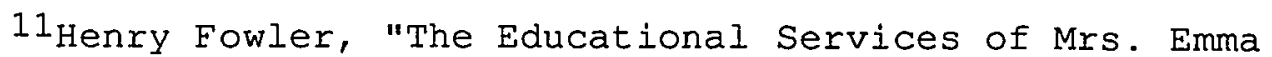
Willard," in Memoirs of Teachers and Educators, 125.

12 Ibid. 
together. She was the one who instilled in her children the distinct values of duty, devoutness, kindness and loyalty.

In Emma Hart's later thoughts, the concept of the mother as the first educator of her children was to hold a central position. She would see the mother as the teacher of virtue and other Christian values. She also came to believe the sphere of the wife and mcther should be separate and subordinate to that of the husband. It can safely be assumed that the example of motherhood Emma Hart held for most of her own life was based, at least in part, on the example set by Lydia Hinsdale. 13

Emma Hart's father, Samuel, great grandson of the Englishman Stephen Hart, was born on a farm in Berlin. In his early youth he had plans to pursue a college education as, "he was a good boy of 'good parts." 14 when Samuel was

${ }^{13}$ Emma Willard's foremost biographer Alma Lutz relates the following story of the women's life on the Hart farm. "After the men had done the shearing, the women sorted the wool, setting aside the best for the father's clothes, the next best for the other men of the family, the third part for themselves." Alma Lutz, Emma Willardi Pioneer Educator of American women, 2. The question here is whether this story is an illustration of simple farm economy as Lutz implies or rather an early example of the subordinate status of women. For an assertion of the second point of view see, Frederick Rudolph, "Emma Hart Willard," in Notable American Women, 1607-1950; A Biographical Dictionary, ed. Edward T. James (Cambridge: Belknap Press, 1971), 610-13. 60.

${ }^{14}$ Catharine M. North, History of Berlin, Connecticut, 
thirteen, however, his father died leaving him to support his mother and sisters.

Years later, when the Revolution against England erupted, Captain Hart, as he was now called, headed a company of volunteers from Berlin who were instrumental in defending the coastal town of nearby New Haven. The Hart farm, along with others in the area, supplied Boston with wheat, rye and corn for the duration of the conflict.

After returning to his farm, Samuel Hart continued the education of Emma Hart, who appears to have been his favorite child. From all accounts, Captain Hart was "a man of marked ability, good early education, intellectual tastes and high moral excellence."15 There is little doubt that Emma Hart's love of knowledge came from observing her father's example. Great works of both fiction and nonfiction were an integral part of Emma Hart's childhood, and learning was a full time proposition in the Hart household. That the Hart household was a fairly intellectual one is evidenced by the time the family spent reading from the great books of Western literature.

Sometimes Mrs. Hart read aloud from Chaucer, Milton or Shakespeare or Captain Hart read while she busied herself with her knitting. Often one of the children read to the

15Mrs. John H. Willard, "A Memorial of the Late Mrs. Emma Willard," 74. 
family from a geography or biography, stopping in difficult parts to ask questions. 16

Emma Hart read everything she could find, and her father discussed the ideas in these books with her, giving her credit for the inteligent mind she possessed. This early training left a lifetime imprint.17 Participating in these discussions with her father, Emma Hart learned to formulate a cogent argument, reason it through, and locate and utilize supportive ideas. She also developed a fundamental belief in education as a dominant force in the progressive improvement of mankind. Finally, Emma Hart gained a kind of internal discipline that would prove beneficial throughout her long life. As her daughter-in-law later noted, Captain Hart "was the best educator of the mind of his daughter."18 "Captain Hart. was a thinker; . . he liked to thrash out ideas."19

\section{Alma Lutz, Emma Willard, Daughter of Democracy, 13-14. \\ 17"He [Emma's father] was fifty years my senior, [Emma} later recalled], yet would he often call me at the age of fourteen from household duties by my mother's side to enjoy with him some passage of an author which pleased him, or to read over to me some essay which he had amused himself in writing." Quoted in Alma Lutz, Emma Willard; Pioneer Educator of American Women, 7.

18 Mrs. John H. Willard, "A Sketch of the History of the Troy Female Seminary," in proceedings of the Thirteenth Anniversary of the University Convocation of the State of New York, held July 12th, 13th and 14th, 1876 (Albany: The Argus Company, Printers, 1876), 170.

19 Alma Lutz, Emma Willard; Pioneer Educator of American Women, 4. 
In his daughter Samuel Hart found a worthy partner for his metaphysical discussions. 20

Emma Hart knew that she owed much of her own intellectualism to her early family environment. Apart from collecting books themselves, her parents encouraged their children to read worthwhile books from their local library. These books provided her with a solid literary foundation.

All of the library's books were read at their firesidePlutarch's "Lives," books of travel, the works of Addison, Pope, Steele, Thompson, Watts, Gibbon and other historians. Emma attributed her love of books to this library and remarked in later years, "Luckily this old library possessed few novels and I had read its books before my rage for fiction began." 21

As books were rare and expensive at that time, it is important to note that the Harts still found money to purchase books, even on their limited income. The books that were purchased were generally classics of the ancient and modern world rather than novels. The choice of this type of book reflected the intellectual atmosphere in the Hart household. Later in her Iife willard was to advise her younger sister Almira to focus on the more "serious" works in order to sharpen her own reasoning abilities.

\footnotetext{
20 "He [Emma's father] delighted in reading and discussing metaphysics, particularly the philosophy of Locke and Berkeley and early awakened in Emma a capacity for metaphysical speculation." Alma Lutz, Emma Willard, Daughter ef Democracy, 20.

21 Ibid., 14.
} 
In the first place, refrain from pampering your imagination too much with novels. You and I ought rather to consult our understanding. A person who has the voyage of a life before her, with too much imagination for her understanding, is a vessel on a boisterous ocean, with too much sail, exposed to a thousand accidents. 22

Captain Hart frequently spent the evening telling the children stories of their family's past. The settling of Connecticut and the Revolutionary wax in particular made impressions on his daughter. Listening to her father speak of the role the Harts and Hinsdales had played in the brief history of America, she developed a lifetime love of history. From her father Emma Hart also absorbed a burning patriotism, an appreciation of her social position and civic responsibility, and a deeply held understanding of the principles of democracy and freedom.23

The example set for Emma Hart by both of her parents was pivotal in supplying the underpinnings necessary for the

22 This letter from Emma Willard to her sister Almira is quoted in John Lord, The Life of Emma Willard (New York: D. Appleton and Co., 1873), 38 .

23 The close intellectual relationship between women of high achievement and their fathers or other significant male members of their family during the period of the late eighteenth and early nineteenth century, has been remarked upon by many authors on both sides of the Atlantic. For an excellent discussion of this special relationship between father and daughter in England see Miriam Lebranbaum, "Mistresses of Orthodoxy: Education in the Lives and Writings of Late Eighteenth Century Women Writers," Proceedings of the American Philosophical Society 121 (August 1977): 281-301. The special relationship between Emma Willard and her father is noted in Anne Firor Scott, "What, Then, is the American: This New Woman?" Journal of American History 65 (December 1978): 683 . 
development of her own set of values. "It was the independence of character thus acquired, the love of knowledge thus imparted by the father, united to this energetic economy, thus enforced by the mother" that gave Emma Hart the capacity to accomplish what she did.24

A significant part of Samuel Hart's personal philosophy was a belief in man's freedom to hold diverse points of view. His belief often guided his deeds. One particular story illustrates Captain Hart's propensity to act upon principle. When two of his neighbors would not in good conscience pay the tax required for the support of the local minister, Hart resigned his position as church treasurer rather than sign the warrant sending them to jail. He then withdrew from the church, paid the taxes of the neighbors and released them from prison; such was his independence of character and his dislike of bigotry or prejudice. 25

${ }^{24}$ Henry Fowler, "The Educational Services of Mrs. Emma Willard," Memoirs of Teachers and Educators, 127.

25 In response to pleas that he continue as church director, Captain Hart is purported to have replied, "Mr. webster. . there are two things in religion which I despise; the one is force, and the other is flattery." Henry Fowler, "The Educational Services of Mrs. Emma Willard," Memoirs of Teachers and Educators, 127. The same story concerning Captain Hart and the local church is related in Lord, The Life of Emma willard, Chapter 2. It should be kept in mind, however, that both Barnard and Lord knew Emma Willard personaliy and admired her a great deal. This fact may have colored their recordings of Captain Hart's statement a little, but the essence seems assured. 
Captain Hart's actions in this case were not lost on his children. Examples of her parents' outward behavior made an impression on Emma Hart and deepened her sense of right and wrong. Consequently, all her life she was to follow the dictates of her own conscience. Her outward actions came to be defined by an internal definition of how things "should be"; a very personal code of ethics.26

Her daughter-in-law was later to say,

Such influences, in early childhood, cultivated Mrs. Willard's superior natural gifts, developed the independence of thought and action, the intense patriotism, capability of metaphysical speculation and rare conversational powers, which later on so eminently characterized her. 27

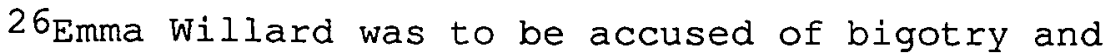
prejudice in her later years, especially when she came to the defense of the status quo during the Civil war period. In assessing the origins of Emma Willard's personal philosophy it is important to recall the great influence of her early New England upbringing, with its emphasis on white, AngloSaxon, Protestant principles. Even the lofty example of Captain Hart's behavior must be seen within this context. The underlying implication here is that only white, educated, Christian males are illustrative of virtuous behavior. Would Captain Hart have been as quick to defend a Black, a Jew, a Hindi or other "pagan"? Later Emma Willard was to assert that she "believ[es] that in the present state of the world our political rights and those of our children are safest in the hands of the educated men of our race." Emma Hart Willard, Via Media: A Peaceful and Permanent Settlement of the Slavery Ouestion (Washington: Henry Polkinhorn, Printer, $1862), 2$.

27Mrs. John H. Willard, "A Memorial of the Late Mrs. Emma Willard," 74. 


\section{Early Education}

Emma Hart's first formal schooling took place at the district school in Worthington Center. It was the beginning of a lifelong love affair with learning, and quite a beginning it was! Benjamin Franklin may have written that the academic institutions of America "should have a well stocked library, an abundance of maps and globes and a variety of scientific instruments in modern laboratories. . . [All this to be] headed by a learned, patient and compassionate rector [and] a tolerant faculty,"28 but the reality of Emma Hart's situation proved to be far different. Like a majority of local schools of the time, the schoolhouse Emma Hart attended was a small, bare, weatherbeaten, single-roomed building, with a fireplace at one end and a single continuous line of desks (which were really just pine boards fastened to the wall) running around the other three sides of the room. Hard wooden benches faced the desks, and when the children studied their lessons or wrote in their homemade writing books, they faced a blank wall. When a student was asked to recite, he or she stepped off the bench and turned to face the center of the room.

28 Abraham Blinderman, American Writers on Education Before 1865 (Boston: Twayne Publishing, 1975), 53. 
The smaller children sat on high, backless stools in the center of the room and read their lessons out loud. Since the oral recitation of long memorized tracts was the standard mode of instruction in most schools of the period, the result was often verbal chaos.29

Based upon her own recollections, Emma Willard believed that she received a fairly good basic education, and there are no tales of her suffering under the tyranny of an autocratic teacher. Later, as she invariably did throughout her long life, she was to draw a lesson for living from those early school days.

The school house was a place of rude structure; but be it remembered, it was fully as good as the dwelling houses. The children were not enervated by luxuries at home. . . . They had learned to "endure hardness as good soldiers." Even the little children had begun to learn the same lesson. 30

29 An excellent discussion of the realities of local schoolroom is contained in Sandra Brandmark Fowler, "The Character of the Woman Teacher During her Emergence as a Full Time Professional in Nineteenth Century America: Stereotypes vs. Personal Histories" (Ph.D. diss., Boston University, 1985). Also of value in assessing the true nature of the early nineteenth century American school is Joel Spring, The American School: 1642-1985. Varieties of Historical Interpretation of the Foundations and Development of American Education (New York: Longman, 1986), Chapters 2 and 4 in particular.

30 Quoted in Alma Lutz, Emma Willard; Pioneer Educator of American Women, 5. Later on in her life Emma was to place great emphasis on the cleanliness and layout of the schoolroom. For example see Emma Willard, "The Schoolmistress, Article Three: The Schoolhouse, "New York Teacher 3 (February 1855): 29-30. 
The quality of Emma Hart's early education appears to have been better than that of the majority of women of the era, whose learning was often abysmal at best. As with other local schools the Worthington school was limited by the knowledge of the teacher, the economics of allowing children to be away from work on the farms, and the lack of proper equipment and supplies.

The best-educated men in the community were generally those who served as teachers during the winter. These men were in the main farmers, lawyers or clergymen. The school term for boys was of necessity short, usually from one to six months and held during the winter when they were not needed on the land to harvest crops. A woman frequently took over the instruction during the summer months when the girls were allowed to attend.

The attendance of girls during the winter months was an innovation that took place during Emma Hart's early years. The spending of money on "girls' schools" was still an issue that was hotly debated. Gradually some young ladies were allowed to attend the whole year-round rather than just during the summer months. 31

${ }^{31}$ The entire subject of the evolution of girls' schooling is obviously beyond the scope of this paper. A later chapter in this thesis will deal with certain, specific ideological, sociological and economic phenomena which coincided directly with and facilitated the formation of Emma Willard's philosophy on women's education. Two excellent works on the history of women's education in America were 
In his seminal work on women's education in the United States, Thomas Woody states that in Boston, "Girls were admitted only one-half of the year however,-the summer-and not until 1828 did they attend year round."32 This statement typifies the situation in most of early nineteenth century New England. Educational opportunities for women would be even slower to materialize in the southern states. 33 It would be some time, also, before children of both sexes would benefit from a set course of instruction. The length of the school term continued to be irregular for several decades, and the exact number of school days attended by children across America during this period varied widely.

found to be indispensable on this topic. These works are Linda $\mathrm{K}$. Kerber, Women of the Republici Intellect and Ideolegy in Revolutionary America, Institute of Early American History and Culture (Williamsburg: University of North Carolina Press, 1980), Chapter 7. The absolute classic in the field, somewhat dated but still invaluable is Thomas Woody, A History of Women's Education in the United States (New York: The Science Press, 1929).

32 Thomas Woody, A History of Women's Education in the United States, 146.

33 Most historians of women's education in the United States have acknowledged the more "ornamental quality" of the education provided for women in the southern states before the Civil War. One author who attempts (rather unconvincingly) to refute this assumption is Anne $A$. Brackett, The Education of American Girls in the South Prior to 1860 (New York: Neale Publishers, 1909; reprint, New York: Zenger Publishers, 1976), 184 (page references are to reprint edition). 
The curriculum of the day was simple: reading, writing, spelling and some arithmetic. Lessons from the old Testament were the first order of the day, followed by the $A B C$ 's for the younger students, and the study of spelling and penmanship for the older pupils. There was a short break for all children (first boys, then the girls) in the middle of the morning, then a lunch break of an hour or so. The afternoon's activities were much the same as the morning's. Later, geography and grammar were introduced for the older students. The girls, of course, practiced their needlework. 34

A break in this monotonous and uninspiring routine of instruction came for Emma Hart when she was fifteen. An academy opened up about a mile from her home in worthington. The opportunities this new Academy provided her were to change her life in unexpected ways.

\section{Academy Days}

Emma Hart and her sister Nancy attended the Worthington Academy (one of the first incorporated in Connecticut) for

${ }^{34}$ For an excellent summary of the progressive expansion of public instruction in the nineteenth century, see Ellwood P. Cubberley, Public Education in the United States: A Study and Interpretation of American Educational History (Cambridge: Houghton Mifflin, 1947), Chapter 5. The gradual admission of girls to year-round instruction is traced regionally in Thomas Woody, A History of Women's Education in the United States, chapters 4, 5, 6 . 
two years, from 1802 to 1803. For a young scholar of Emma Hart's disposition it was time well spent. Of her days at the Academy she wrote, "I believe that no better instruction was given to girls in any school at that time, in our country. " 35

These thoughts, polished by age and wisdom, were written down much later in Emma Hart's life, and they reflected her mature position. Initially she had no intention of being a scholar, as her own words reveal.

I stood one evening, candle in hand, and made to my parents, who had retired for the night, what they considered a most sensible oration, on the folly of people's seeking to be educated above their means and prescribed duties in life. So Nancy went to school and I to Kensington. 36

However, when she saw the books that her sister brought home from school, Emma Hart changed her mind. Quickly and promptly she told her mother, "I am going to school tomorrow." And go she did.

35 Female academies in late eighteenth century America have usually been assessed as having little value in the progress of women's education. An excellent new study refutes this assertion and provides ample evidence that several Female Academies were critical in the later accomplishments of women like Emma Willard, Catharine Beecher and Mary Lyons. Lynne Templeton Brickley, "Sarah Pierce's Litchfield Female Academy, 1792-1833," (Ph.D. diss., Harvard University, 1985).

36 Henry Fowler, "The Educational Services of Mrs. Emma Willard," Memoirs of Teachers and Educators, 128. 
Some of the credit for the awakening of Emma Hart's intellectual abilities can be attributed to her acquaintance with a Yale graduate named Thomas Miner who was the principal of the Worthington Academy at that time. 37 Miner saw in Emma Hart something extraordinary and challenged her abilities by providing a more stimulating educational situation than she might have gotten elsewhere.

Handing Emma Hart a copy of Webster's Grammar and Morse's Geography, (two standard, popular textbooks of the day), Miner told her to begin her studies. In three days she had made up for all of her lost time and had overtaken the rest of the class. From this point on, there was to be no holding her back.

Emma Hart's desire to learn, coupled with a strong sense of duty derived from her New England home life, made her an exceptionally diligent worker. A story is told about her during this time which illustrates her ability to concentrate. One night she was upstairs in her room attempting to learn a "hard chapter" in her geography book. Downstairs, her sister Nancy and some of her friends were

37 Thomas Miner was a 1796 graduate of Yale, who took up teaching because of poor health. Later he became an eminent physician. According to F.B. Dexter, he singled out Emma Willard as one of two students of whom he was particularly proud. F.B. Dexter, Biographical Sketches of the Graduates of Yale College with Annals of the cellege History (New Haven: Yale Press, 1912) 5: 206-10. 
having a party. Unable to completely block out the loud noise and laughter, she wrapped herself in a warm cloak to keep out the winter chill and went outside to study. Sitting on a horseblock, she stayed out in the cold night air until she had thoroughly memorized the planets' diameters, distances and periodic revolutions. Such dedication to learning is rare in any adolescent, but with the possibility of a party to attend as an alternative, it seems exceptional. No one ever had to push Emma Hart to do her lessons.

A second person who saw in Emma Hart the makings of something special was a local woman named Mrs. Peck.38 In 1804, when Emma Hart was seventeen, Mrs. Peck suggested that she should be placed in charge of a children's school in the village. Emma Hart agreed. It was the beginning of a teaching career which would last over forty years, but it was a rocky beginning.

When she took over the class, Emma Hart found to her dismay that her predecessor had paid little or no attention to the discipline of the children. Consequently, the first morning of instruction was a disaster. The youngsters constantly jumped up and ran to the windows to look at passing carriages, stepped on the benches in the classroom or

38 I have been unable to find any biographical information on Mrs. Peck other than Emma Willard's references to her as "my friend." 
dashed out the doors to play in the yard beyond. She was frantic. "Reasoning and pathetic appeals were alike unavailing," she later said.

At noon break she asked her friend, Mrs. Peck, what to do. Mrs. Peck "decidedly advised sound and summary chastisement." Emma Hart replied that she had never struck a child in her life and could not do it. However, she soon found that it was the only way to gain the authority and respect necessary if she was to teach her pupils anything at all. "I spent most of the afternoon in alternate whippings and extortions [she later wrote]. . until at last, finding the difference between capricious anger and steadfast determination, they submitted."39

In this early instance, Emma Hart discovered an ability to gain the respect of her students by keeping them just a little afraid of her authority. Later in her life she was to advise teachers to be loved and yet feared. "You should be patient, but you must govern. . . You must go before your school prepared to govern as to teach."40 The belief in a gentle but firm approach to discipline which was to mark her

${ }^{39}$ Quoted in Alma Lutz, Emma Willard; Pioneer Educator of American Women, 9.

40 Emma Willard, Letter Addressed As a Circular to the Members of the Willard Association for the Mutual Improvement of Female Teachers: formed at the Troy Female Seminary, July, 1837 (Troy: Elias Gates, 1838), 12. 
later teaching style was gradually developed through experience.

\section{Learning to Teach}

Those first months of teaching showed Emma Hart that she had a great deal to learn, so in order to broaden her horizons she attended a school in Hartford operated by "The Misses Pattens." At the Pattens' school, she learned about the "primary and essential branches," while practicing her needlework, lacework and embroidery.

The next autumn and spring she attended a school operated by Mrs. Lydia Bull Royce. With Mrs. Royce, she studied "Reading, writing, arithmetic, geography, French, dancing, drawing, painting and more needlework. . . Tuition for fourteen weeks was $\$ 7.62$ with extras for drawing and needlework materials." 41

While she attended Mrs. Royce's school as a day scholar, she lived in the home of Dr. Sylvester Wells. Dr. Wells was known locally as a brilliant man who held rather liberal

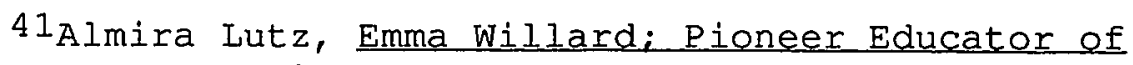
American women, 10. The charges at Mrs. Royce's school appear to be in line with other similar ladies' schools of the time. Thirty-five years later Emma Willard was to charge $\$ 200.00$ per annum or $\$ 100.00$ per term for the basic course of instruction for her boarding pupils at the Troy Female Seminary and had students being turned away even at that price. Catalogue of the officers and Pupils of the Troy Female Seminary for the Academic Year Commencing March 8 , 1843 and Ending February 21, 1844 (Troy: N. Tuttle, 1844), 12 . 
views on religion and medicine. Between Emma Hart and Dr. Wells there developed a firm friendship. As they discussed all kinds of topics, including the writings of John Locke and the Enlightenment philosophers, Dr. Wells came to appreciate her keen mind and quick wit. Wells ignored the fact that Emma Hart was female and challenged her use of her mind to its utmost in exploring her beliefs. 42

During this period of her life, Emma Hart's views on religion changed. Like her father, she disliked the intolerance of orthodox religion. Yet she had received a fundamentally Christian upbringing, and she was not comfortable moving very far into the realm of metaphysical speculation. This meant that, as with most Americans of the nineteenth century, Emma Hart would carry with her throughout her life a belief that God directly affected the lives of men. Even so, unlike many in her day, she refused to have that direction defined too dogmatically. 43

42 Her friendships with older men were most fortunate. Dr. Miner, Dr. Todd and Dr. Wells all appreciated her fine mind, conversed with her on equal terms, and helped her in her quest for knowledge. Alma Lutz, Emma Willard, Daughter of Democracy, 31 .

$43_{\mathrm{An}}$ excellent discussion of the views of God and man in nineteenth century America is contained in Ruth Miller Elson, "God and Man," chap. in Guardians of Tradition, American Schoolbooks of the Nineteenth Century (Lincoln: University of Nebraska Press, 1964). 
Her discussions with Dr. Wells left their mark on Emma Hart's thoughts in several other ways. Among other things, she refined her own belief in the rationality of man and the ability of science and education to develop society. She also began to resolve conflicts between wells's scientific rationalism and the fundamental values of her own Christianity. Finally, on the practical side, she gained further experience in carrying on an educated, philosophical. conversation with men. 44 "Thus trained it was natural that [for Emma]. . . the philosophy of the mind should be a favorite study." 45

In the winter of 1806, just before she had left to attend Mrs. Royce's school, Emma Hart had taken charge of the Berlin Academy (the same school she had attended under Dr. Miner) for a short period. Gradually her talents as a teacher were becoming widely known. In 1807, when she reached her twentieth birthday, Emma Hart received three offers of employment: one in Westfield, Massachusetts,

\footnotetext{
${ }^{44}$ Perhaps the best way to describe her views on religion during this period is to say that she agreed with her father; Religion was simply "a Right Temper of Mind." Later, when Emma Willard established the Troy Female Seminary, she made a determined effort to provide a solid, Christian education for her young ladies without aligning the school itself with any particular religious denomination. The girls were free to attend almost any church they wanted during their tenure at Troy.

45 Mrs. John H. Willard, "A Sketch of the History of the Troy Female Seminary," 171.
} 
another in Middlebury, Vermont, and a third in Hudson, New York. Choosing Westfield Academy because it was nearest to home, she became an assistant there in the spring of that year.

However, her tenure at Westfield was short lived. Having previously been her own boss to some degree, Hart felt that she was under too many restrictions in her new position. The Academy administrators took a dim view of her attempts to implement newer methods of instruction. So, since the offer of employment in Middlebury was still open, Emma Hart resigned her position in Westfield to take complete charge of the Academy at Middlebury. 46

The town of Middlebury, Vermont, was a quiet, dignified college town with conservative traditions. The fabric of town life was deeply intellectual, and Emma Hart discovered that "there was in Middlebury an unusually large number of educated men, graduates of Yale and Dartmouth and Brown."47 As the new head of the Academy, Emma Hart soon found herself in the middle of this little aristocracy, and she found it

46 Emma Willard gave up her position in Westfield even though the trustees of the school had told her she could name her own salary, an action quite unheard of.

47 Ezra Brainerd, Life and Work in Middlebury, Vermont of Emma Willard (New York: Evening Post Job Printing House, 1893), 3 . 
all quite amazing. In a letter to her parents, written

during her first year in Middlebury, she said:

I find society in a high state of cultivation-much more than any other place I was ever in. The beaux here are, the greater part of them, men of collegiate education. . - Among the older ladies, there are some whose manners and conversation would dignify a duchess. 48

Operation of the school was no easy task. Originally opened in 1800, the same year as Middlebury College for men, the Middlebury Female Academy had fallen into disrepair and eventually had closed in the summer of 1807 because of the poor health of its instructress, Miss Ida Strong. Emma Hart was charged with reopening and rejuvenating the Academy. Typically, she threw herself into the project with all the diligence that had marked her earlier scholastic efforts. In

a letter to her parents in August of 1807 she wrote:

I go to school generally before nine, and stay until one; come home, snatch my dinner, go again, and stay till almost sundown; come home, and dress in a hurry to go abroad; get home about ten, fatigued enough to go to bed, and lie till seven the next morning, with hardly enough time to mend my stockings. Sunday I attend four meetings. My situation is a very trying one, in some respects. 49

And difficult her situation truly was, as Emma Hart was seemingly under siege from all sides. The building that housed the school had been unused for many years and was in a

48Ibid., 3-4. Also, Alma Lutz, Emma Willard, Daughter of Democracy, 34 .

49 Emma Hart Willard to her parents, August, 1807. Typescript of letter in Emma Willard School Archives. 
bad state of repair. In the winter, the chilly northern Vermont wind whistled through the walls and penetrated into the schoolrooms, wrapping both pupils and teacher in an icy cloak.

Out of necessity, Hart incorporated physical exercise into her curriculum. Arranging her girls "two and two in a long-row for a contra-dance," she instructed a few to sing a "stirring tune." With one of the young ladies as a partner, she "would lead down the dance, and soon have them all in rapid motion. Afterwards they would return to their school exercises," well and truly energized.50 It was not the first, nor the last time Emma Hart's teaching techniques would spring from necessity.

Aside from the physical discomfort with which she had to contend, there were those in the town who attempted to undermine the efforts of the school by quarreling over religious differences. These interdenominational disputes

50 Ezra Brainerd, Life and Work in Middlebury, Vermont of Emma Willard, 6-7. In later years Emma Willard, like Catharine Beecher, Mary Lyon and others, would become a firm believer in the value of physical exercise for ladies. In reporting on the operation of a curriculum designed by Emma Willard for the East Kensington District of the Common Schools, the Committee observed that, "They [the children] are not kept more than an hour confined, before they are allowed to sport in the wood just by, or on the green bank of the hillock. . . ." "Female Common School Association in the East District of Kensington, Connecticut," American Journal of Education 15(1865): 616. 
were precisely the type of arguments which exasperated her. Dogmatic quibbling held little sway with Miss Hart due to the religious tolerance she had inherited from her father. She learned to manage the "politics" of community life, however, and emerged from this situation unscathed. Observing Emma Hart throughout her ordeals was a distinguished older gentleman named John Willard. As Dr. John Willard watched her attempting to cope with warring townsfolk, recalcitrant schoolboards and unruly students, his admiration of her abilities grew. Soon he was to become not only her truest friend, but also her guiding support, business partner and husband.

\section{Marriage and the Birth of an Idea}

Although her tenure at the Middlebury Academy was a success, Emma Hart resigned her position in 1809. On August 10 of that year she married Dr. John Willard, who was twentyeight years her senior.

John Willard had grown up on a Connecticut farm, gone to sea, served in the Revolutionary Navy, been captured and released by the British, and returned home to study medicine. He had been married twice before and had four children: three boys and a girl.

Tiring of his profession, Dr. Willard had given up his practice and gone into politics. He had been appointed 
Marshall of the District of Vermont during Jefferson's administration. His leadership abilities rapidly became apparent, and he soon became an important power in the Republican organization in Vermont. When he married Emma Hart he still held the position of Marshall, as well as several others, such as supervising the collection of the district tax imposed by the Federal Government, paymaster of pensions and Vermont Republican organization chairman.

John Willard's financial position appeared assured. He owned several farms near Middlebury, and he had just built an imposing new brick house on Main Street. He was also a director of the Vermont Bank. Interestingly, Emma Willard's first significant action in the cause of women's education came indirectly from her husband's association with this same bank.

From all accounts, the Willard's marriage was an extremely happy one in spite of the differences in their ages. Except for some bad feelings between Emma Willard and her newly adopted stepchildren, all signs seemed to point to a long, quiet married existence for Emma Willard.51 In a few

51 Despite what seems to be sincere overtures on the part of Emma Willard to make a family with Dr. Willard's stepchildren, it took many years of effort for them to overcome their feelings that she had married their father just for his money and position. "Why should I have married your father from other than pure motives?" Emma would write to Dr. Willard's son Benjamin Franklin Willard twelve years later. Emma Hart Willard to Benjamin Franklin Willard, 1821. 
years her own son, also named John, arrived, and she settled down to be a loving wife and mother.

The relationship between Emma Willard and her husband was critical in the development of her personal philosophy for three very important reasons. First and foremost was the character of John Willard himself. Unlike many men of his day, Dr. John Willard was prepared to respect and admire intellectual capabilities in a woman. Thus, like several other men in her early life (her father, Dr. Wells and Dr. Miner come immediately to mind), John Willard became her mentor and teacher. Although he was a much older man, he never dominated or stifled the personality of his much younger wife.

Dr. Willard was delighted with [Emma's] interest and ability. Instead of crushing that interest, as practically every man of that day would have done,. . . he encouraged her in her studies, and their days together were filled with happy, intelligent companionship. A great deal of the credit [for Emma's intellectual development] is due Dr. Willard for his broadmindedness. 52

Secondly, John Willard provided a world perspective and maturity which helped her to broaden her own somewhat more limited viewpoint. In a word, he was her counselor and confidant as well as husband. Throughout their life together

Typescript of a letter in the Emma Willard School Archives, Troy, New York.

52 Alma Lutz, Emma Willard, Daughter of Democracy, 44. 
Emma Willard would always rely on her husband's common sense and business acumen. 53

As independently minded as Emma Willard was proving to be, however, she was often dependent upon her husband for encouragement and advice. 54 This dependence was not simply the Victorian dependency of woman upon man; Emma Willard truly valued her husband's insights. In 1825, when he died,

53"There [Middlebury], Emma married Dr. John Willard, whose moral support for his wife's burgeoning ideas for the education of women counter-balanced the reluctance of the local elite to entertain anything novel in that regard." Pierre D. Lambert, "Women in Education: The Known, The Forgotten, and the Unknown," Vitae Scholasticae 2 (Spring 1983).

${ }^{54}$ As he lay near death, John Willard continued to worry about the financial well being of his wife. In a document signed shortly before his death Dr. Willard relates information which he believes Emma Willard needed to know. The subject of Willard's letter is the arrangement Emma Willard had made for joint publication of a geography text with William Woodbridge. Dr. Willard was convinced that Emma had unknowingly "signed away her right. . . as the inventor of a new system." Her husband's guidance in these types of business matters was critical to Emma Willard throughout her life. Keeping his wife's future in mind, he closes with the statement,

Being apprehensive that I am now near the close of my mortal existence I have thought proper to have my testimony to these facts committed to writing, thinking that in some future turn of Mrs. Willard's affairs, it may be important to her to possess it.

"Testimony of Dr. John Willard concerning alleged pirating by William C. Woodbridge, of Mrs. Willard's ideas for a geography textbook, April 26, 1825." Typescript copy of document in the Emma Willard School Archives. Original in the Mrs. Hewlett Scudder/Emma Willard collection, Russell Sage College Library, Troy, N.Y. 
she was overcome with grief. "Their married life had been one of such sympathy and understanding and she had instinctively turned to him for encouragement in her hopes and plans. . "55 Finally, John Willard provided further impetus for his wife's continuing intellectual development. First as a physician and then as a politician, John Willard's affairs meant that he often traveled far from home. Motivated by her desire to be an interesting partner, Emma Willard began reading her husband's medical textbooks. She had always been curious about science, and her husband strongly supported her efforts in this direction.

Like many scholars in nineteenth century, Emma willard had a lifelong fascination with science. 56 she liked anatomy and physiology in particular, but she also read books on biology, botany and chemistry as well. It was very unusual for a woman to be interested in science, and not many women of that time dared to explore this area. That willard did

55Alma Lutz, Emma Willard, Daughter of Democracy, 113.

${ }^{56}$ Later in life Emma was to formulate the theory that the respiratory system was the scientific basis for the circulation of the blood in the human body. Her theory met with some polite success but has generally been seen by historians as only a curiosity. Emma Willard, Treatise on the Motive Powers Which Produce the Circulation of the Blood. (New York: Wiley and Putnam, 1844). Emma also came up with her own discussion of the causes of cholera which is in much the same vein. Emma Willard, Respiration and Its Effects: Most Especially in Relation to Asiatic Cholera and other Sinking Diseases (New York: Huntington and Savage, 1849). 
suggests what is true; she was different from her female contempories.

While Emma Willard's particular love affair with science was based in part upon her own particular personality, she was to some degree representative of the general intellectual and cultural climate of the times. Two main influences were at work in society at large--one was economic, the other was philosophical. The main economic influence was the nineteenth century Industrial Revolution in the United States. A growing and expanding America demanded scientific technology that could rapidly be applied to situations in business, finance and trade. Great amounts of money were made by those men who could think of a "better mousetrap." Science, it was believed, was the key to solving all the world's problems.

Philosophically, the nineteenth century's unwavering belief in the effectiveness of science came as an inheritance from the Enlightenment. Writers such as Locke, Condorcet and Turgot made man's rationality the basis of all human progress; the scientific method almost became a religious practice. In his classic work on political theory, George Sabine sums up this legacy. "Nothing characterizes social thought in the eighteenth century so completely as belief in the possibility of happiness and progress under the guidance 
of reason."57 America embraced this philosophy with a vengeance.

Emma Willard would come to incorporate much of this same universal faith in science into her own thoughts. Unlike many people, though, she would more easily accommodate the tenets of her New England Christianity with this new faith in Newton's "clock-work universe."58

While Emma Willard grew intellectually under the guidance of her husband, on her own she began developing a profound awareness of the poor state of women's education. Her newfound consciousness was encouraged by her acquaintance with her husband's nephew. This nephew, also named John, was living with the Willards while he attended Middlebury College.

ares

Through her relationship with her husband's nephew, Emma Willard discovered two facts. First, she found the curriculum that nephew John was studying at Middlebury College was vastly different from what she had been taught during her years in school. The subjects that John studied, ranging from astronomy to zoology, were not part of the

57 George H. Sabine, A History of Political Theory, 3rd ed., (New York: Holt, Rinehart and Winston, 1961), 550.

58 Emma Willard, "Will scientific education make Woman lose her sense of dependence on Man?" Literary Magazine of New York (1832), quoted in Lutz, Emma Willard, Daughter of Demecracy. I have been unable to locate a copy of this article. 
female curriculum; the books he studied were not part of the school texts she had studied in her own school days. It appeared that there were boundless fields of knowledge which were not open to women. "My [closeness] to Middlebury College made me bitterly feel the disparity between the two sexes," she wrote. 59

Second, Willard found, because of her sex, she was barred from participating in an academic system that taught these subjects. When she asked to attend lectures at Middlebury College, her request was denied. In frustration, Willard began studying the subjects on her own. Because she had always been interested in mathematics, she began with geometry.

By using her nephew's textbooks and by listening to him discuss his classroom lectures at the College, Emma Willard began to teach herself. It was to become a lifelong habit. Later she added new subjects to the curriculum of her own schools by first mastering the subject herself and then teaching it to others. In this way she was able to become a "teacher of teachers."

After she had worked her way through Euclidean geometry, she presented herself to her nephew in order to undergo the most rigorous examination he could muster. Emma Willard

$59 \mathrm{John}$ Lord, The Life of Emma Willard, 34. 
wanted to prove that the widely held belief that women's minds could not handle the rational, logical progression of higher mathematics was wrong. At the close of the examination her nephew pronounced her every answer completely correct.

In his account of this period in Emma Willard's Iife, Ezra Brainerd, President of Middlebury College in 1863 gives an essentially accurate picture of her scientific awakening. It is worth quoting at some length.

Then at another time she takes up the study of geometry. Dr. Willard has a nephew in college who lives with them--his namesake--afterwards for many years Judge of the Supreme Court of the State of New York. One vacation she takes his Euclid and reads on, proposition after proposition, fascinated by the study. She thinks she understands it; but the prevalent belief in the incapacity of the "female mind" for mathematics causes misgivings, until she submits herself to her nephew for examination, and he pronounces her learning correct. 60

After she mastered mathematics, Willard went on to the study of natural philosophy. She read through the most popular books of the day on the subject including Paley's Moral Rhilosophy and Locke's Essay Concerning Human Understanding. 61 John Locke's arguments in particular would

60 Ezra Brainerd, Life and Work in Middlebury, Vermont of Emma Willard, 7-8.

61 "Moral Philosophy," a mish-mash of logic, Christianity and philosophy was just one of many courses in morals offered under the guise of "philosophy" in women's schools of the period. All were attempts to rationalize religion in the beginning of the nineteenth century. Thomas Woody, A History of Women's Education in the United States, 414,418. Also, 
come to have a bearing on her own pedagogy. Locke's belief in man's rationality reinforced Willard's growing faith in her own and other women's reasoning abilities. 62

Emma Willard was fascinated not only by science and philosophy but by history and current events as well. Inspired by the War of 1812, the expansion westward and America's ever-developing economic power, a new generation of fiery speakers such as Clay, Calhoun and Webster proclaimed the dawning of Americanism as a creed. All of these events interested her and strengthened her belief in America as God's chosen land. As it had been with her father, history was always Willard's first true love.

As she worked her way through various academic subjects, she began to ponder ways to improve women's educational position. Always an active person, willard looked for methods that could be used to balance the unequal scholastic equation between man and woman. The answer came to her in both a practical and philosophical way.

Ruth Miller Elson, Guardians of Tradition, American Schoolbooks of the Nineteenth Century, 43-44.

62 Several authors have noted that Locke does not seem to have argued against a rational education for women. See for example, Alice Browne, "Women's Education and Women's Rationality," chap. in The Eighteenth Century Feminist Mind (Detroit: Wayne State University Press, 1987) and Jane Roland Martin, Reclaiming a Conversation: The Ideal of The Educated Woman (New Haven: Yale University Press, 1985). 
About this time the Middlebury branch of the Vermont State Bank was forced to close its doors because of a major robbery. Although there was never any evidence of complicity on their part, the Directors of the bank (among them Emma Willard's husband, John Willard) were required to make good the losses. The result for the Willards was a severe financial reverse. Along with their financial problems, Emma and John Willard suffered a corresponding reverse in their social position. 63

Throughout this time of trouble, Emma Willard retained her courage and her belief in her husband's integrity. She also decided there was something she could do. To assist in the restoration of the family income, she decided to open a boarding school in her home. With this decision, in the spring of 1814, what would become the Middlebury Female Seminary began operation. The Seminary was the first practical application of her belief in the necessity for a different kind of female education. Although Emma Willard wrote that "My leading motive was to relieve my husband from

${ }^{63}$ Later on a false key was discovered in the bank's attic, and the directors were completely absolved from any hint of wrong doing. A complete account of the robbery itself can be found in Samuel Swift, History of the Town of Middlebury in the county of Addison, Vermont, (Middlebury, n.p., 1859), 326-27. 
financial difficulties. . I also had the further motive of keeping a better school than those about me." 64

The result of this desire to provide a "better school" was an education far different from the superficial studies typically given to girls of that day. The experience Emma Willard gained from the operation of her school formed a practical basis for her experimentation in new and different instructional techniques. Further, this same experience provided validation of a pedagogy which was just beginning to form in her mind.

Over the next few years, her teaching experiences gave her the ammunition she needed to refute the charges of women's intellectual inferiority. She could point to the successes of her own young ladies.

Finally, this period of her life provided the philosophical basis for her first major work on women's education, appropriately entitled, An Address to the Public: Particularly to the Members of the Legislature of New York, Proposing a Plan for Improving Female Education.

The final version of Emma Willard's Rlan was a mixture of values gained from her early family life and a personal love of learning. She dug back into her early school days and extracted those items of importance: hard work, the call

64 Henry Fowler, "The Educational Services of Mrs. Emma Willard," Memoirs of Teachers and Educators, 133. 
of duty, democratic patriotism and a belief in the use of education for the progression of society.

That she wrote the Plan at all was the result of the influence and guidance provided by the important men in her life: her father, her husband and others. 65 without their encouragement, it is doubtful whether she would have been confident enough to write the plan. Further, without the belief in her own abilities that these men had fostered, she would probably not have actively pursued its implementation. The Plan illustrated that Emma Willard had learned a great deal during her early years of teaching. She had begun to see that women were capable of learning a great deal more than most people assumed. She could now rely upon a storehouse of personal experiences in the classroom to verify a set of emerging beliefs. She had convictions about the way education should work, how children learn, the reasons for education and the value of instructional design and method. In short, she had begun to delineate her own personal educational philosophy.

\footnotetext{
65 The death of Emma Willard's father in August of 1813 was a great blow to her. To commemorate the occasion she wrote a memorial poem. Like all of Emma Willard's poetry the work displayed the fact that, at least in this area, Emma Willard possessed more sentiment than talent. See Alma Lutz, Emma Willard, Daughter of Democracy, 49, for an example of the poem.
} 


\section{CHAPTER THO}

\section{EMMA WILLARD'S EDUCATIONAL PHILOSORHY : THE ROLE OF WOMEN}

The publication of An Address to the Public:

Particularly to the Members of the Legislature of New York, Proposing a Plan for Improving Female Education marked the beginning of Emma Willard's public efforts on behalf of women's education. In it she articulated beliefs which changed little throughout her life. Her objective was clearly stated in the first sentence of the work. "The object of this address is to convince the public that a reform, with respect to female education, is necessary."1 Having little faith in the results of private benevolence, willard sought to justify the expenditure of public funds on a female seminary which would provide continuity and order for women's learning. 2 As Anne Scott

${ }^{1}$ Emma Willard, An Address to the Public;

Particularly to the Members of the Legislature of New York, Proposing a Plan for Improving Female Education (Middlebury: J.W. Copeland, 1819), 1.

2 Trying to decide what to call her new school for women in Middlebury, Emma Willard was torn between a desire to call it a college and a fear that doing so would raise the ridicule of the public. She settled upon the idea of a Female "Seminary" after she ". . . heard Dr. Merrill pray for 'our seminaries of learning'." The term gradually came into general use in designating women's schools of somewhat higher learning than the Female Academy of the late eighteenth 
has pointed out, the plan "ingeniously combined tradition and innovation. . ." by arguing that

1. It is the duty of government to provide for the present and future prosperity of the nation.

2. This prosperity depends upon the character of the citizens.

3. Character is formed by mothers.

4. Only thoroughly educated mothers are equipped to form character of the quality necessary to insure the future of the republic. 3

At the center of this practical document lay Emma Willard's beliefs about the nature of woman. Her plan (and various later works) reflected three fundamental philosophical tenets concerning woman's mental abilities, social roles and familial duties. All three tenets directly influenced her educational philosophy.

First, Emma Willard believed in woman's ability to grasp abstract ideas and to develop logical arguments. Her own scholastic background seemed to validate her belief that education could train a person, male or female, to do so. Later, her teaching experiences showed her that young girls could understand complex problems. It followed that part of the function of education was to nurture this rationalism in women. "Females, by having their understandings cultivated,

century. Story quoted in Alma Lutz, Emma Willard, Daughter of Democracy (Boston: Houghton Mifflin, 1929).

${ }^{3}$ Anne Firor Scott, "The Ever Widening Circle: The Diffusion From the Troy Female Seminary: 1822-1872," History ef Education Quarterly 19 (Spring 1979): 6 . 
their reasoning powers developed and strengthened, may be expected to act more from the dictates of reason, and Iess from those of fashion or caprice, . . .4

Second, Willard felt that there was a special relationship between mother and child. The mother was the first teacher of the child--the instiller of morality and virtue. Women, she believed, were by nature fitted for the instruction of children. As such, the supervision of childhood education was the logical domain of women. By paying careful attention to the early relationship between mother and child, the character of the individual child was improved and a better overall moral tone was fostered for American society. Proper maternal care was critical for everyone concerned,

for who can weigh, or measure, or estimate the difference to a parent, especially a mother, between a good child, coming forward to be a good man or woman, and a bad child, growing up to be miserable in himself, a torment to his family and a pest to society. And how many such have died an untimely death, with curses upon careless mothers. 5

Finally, Emma Willard held a firm belief that God and nature had defined a separate sphere for women. Woman's

4Willard, Plan for Improving Female Education, 26.

${ }^{5}$ Emma Willard, "Letter from Mrs. Emma Willard, on a 'Proposed Plan of a Female Association to Improve Schools'," in "Female Common School Association in the East District of Kensington, Connecticut," American Journal of Education 15 (November 1865) : 615 . 
sphere of influence was centered in the family, and it was ultimately subordinate to that of man. "Man is the head of human society. . . . By the plastic energy of her nature, [woman] will rise to fulfill whatever trust she may receive from the affectionate confidence of him, who is at once her companion and sovereign." 6 The function of female education was to prepare women to accept their natural role in society as wives, mothers and possibly as teachers.

This chapter explores the three main beliefs held by Emma Willard concerning the nature of women: women as rational beings, women as mothers, and women as members of society. All three roles contribute to the shaping of her educational philosophy.

\section{The Rational Woman}

"You need not be told how much female Education is neglected, nor how fashionable it has been to ridicule Female learning," Abigail Adams wrote to her husband in 1778.7 Indeed, many in the growing republic openly dismissed the

\footnotetext{
6Emma Willard, Letter to Dupont de l'Eure on the Political Position of Women (Albany: Joel Munsel1, 1848), 15. Typescript copy, Emma Willard School Archives, Troy, New York.

${ }^{7}$ Quoted in Linda $K$. Kerber, women of the Republic: Intellect and Ideology in Revolutionary America, Institute of Early American History and Culture (Williamsburg: University of N. Carolina Press, 1980), 191.
} 
idea that women were capable of understanding anything beyond being simply "pleasing."

Whether women could think rationally or not was a debate which had raged in Europe for centuries. As early as 1694, Mary Astell asserted that, "Altho' it has been said by Men of more Wit than Wisdom, and perhaps of more malice than either, that women are naturally incapable of acting Prudently, or that they are necessarily determined to folly, I must by no means grant it." 8 Naturally, questions concerning the rationality of women directly affected discussion about whether or not women should be educated.

By the end of the eighteenth century most Europeans had accepted the idea that women should receive some form of education. The controversy then shifted to the type of education necessary. The necessity to clarify issues concerning the kind of education women should receive became particularly acute as the middle class continued to grow. The daughters of upwardly mobile professionals and wealthy tradesmen were unable to find schools which would provide more than simple academic instruction. 9

\section{Bridget Hill, ed., The First English Feminist:} Reflections Upon Marriage and Other Writings by Mary Astell (London: St. Martin's Press, 1986), 143.

${ }^{9}$ For a discussion of the role of education in the upward mobility of nineteenth century British women see P.J. Miller, "Women's Education, 'Self-Improvement', and Social Mobility," British Journal of Educational Studies 20 (October 1972): 303-14. 
Educators in both Europe and America were divided.

Anti-feminists who felt that women's training should make them pleasing to their husbands based their curriculum design upon so-called lady-like "accomplishments."10 Doubting a woman's ability to think rationally, they wanted the kind of education which emphasized taste and feeling. Reformers, on the other hand, sought an education for women that was intellectual and useful, both to the family and to society. Enlightened European men and women argued that although a woman may not be able to think equally as abstractly as a man, she was capable of some sort of rational thought.

A wide range of opinions on the topic fell between these two poles. On the subject of women's education, the position of most Americans during this period can (with some qualifications), be drawn in much the same terms.11

10 For an excellent bibliography of source material (both primary and secondary) dealing with the Anti-Feminist viewpoint in nineteenth century America see Cynthia D. Kinnard, "Education of Girls and Women," chap. in AntiFeminism in American Thought: An Annotated Bibliography, (Boston: G.K. Hall, 1986).

${ }^{11}$ The qualifications which must be placed upon a comparison of American attitudes toward women's education and those of the Europeans and British of the nineteenth century include concepts of social class and patriotism. These areas will be dealt with in a later chapter of this thesis. For an interesting description of the foreign viewpoint of American schools see Sophia Jex-Blake, A Visit to Some American Schools and Colleges (London: Macmillan and Co., 1867; reprint, Connecticut: Hyperion Press, 1976). 
However, the argument about what constituted the proper female curriculum still begged the question. Was woman capable of rational thought or wasn't she? Both sides failed to address the core of the problem directly. As Alice Browne has pointed out in her article "Women's Education and Women's Rationality," "Neither kind of education was necessarily feminist, for neither necessarily respected women's minds or taught them to think." Browne concludes that, "Increases in the range of women's education are not in themselves advances in respect for women's rationality."12

Emma willard did believe that women were rational beings and she was convinced that proper schooling fostered this rationality. She believed that women were capable of formulating logical arguments, of thinking in the abstract, and of discussing substantive topics. She knew that women could do these things without lessening their "femininity." In beginning a discussion of Emma Willard's educational philosophy two primary questions must be answered. First, how did Willard define "rationality" without reference to

12 Alice Browne, "Women's Education and Women's Rationality," chap. in The Eighteenth Century Feminist Mind, (Detroit: Wayne State University Press, 1987), 104. For a more global view of the position of women vis a vis education, see Thomas Woody, "Conception of Women's Position and Education in Other Lands," chap. In A History of Women's Education in the United States (New York: The Science Press, 1929). 
gender? Second, how was her definition of a "rational being" interwoven into her thoughts on women and their education?

\section{Toward a Definition of "Rational"}

Aside from her own scholastic background and a general exposure to the prevailing intellectual climate of the day, Emma Willard's definition of rationality was essentially an Enlightenment one. This definition owed much to John Locke and his later interpreters. Several biographers have noted that early in her life she read Locke's Essay Concerning Human Understanding. Later on, his works became standard instructional fare for her own students. 13

Both John Locke and Emma Willard saw the use of language as central to the development of "reason." Both felt that the purpose of education was to facilitate the growth of intelligent communication. Both had an unshakable faith in

13"Of all the studies which I myself pursued, the philosophy of the human mind is that one which I love the best, and have studies the most. I have taught it with little interruption for sixteen years; using as textbooks, first Locke. . . ." Emma Willard, Advancement of Female Education, or a Series of Addresses in Favor of Establishing at Athens, in Greece, a Female Seminary, Especially Designed to Instruct Female Teachers (Troy: Norman Tuttle, 1833), 39. For verification of Willard's reading of Locke's Essay Concerning Human Understanding see Alma Lutz, Emma Willard, Daughter of Democracy, 45; Henry Fowler, "The Educational Services of Mrs. Emma Willard," in Henry Barnard ed., Memoirs of Teachers, Educators and Promoters and Benefactors of Education, Literature and Science (New York: F.C. Brownell, 1861; reprint, New York: Arno Press, 1969), 128. 
the absolute terminology used in mathematics to discipline the mind.

Consequently, the meaning of words, the generalized definition of ideas, and the universal application of terms received considerable attention by both writers. In addition, both Willard and Locke believed that words structured the very process of reasoning. Thus, the way in which words came to represent ideas was central to a definition of what can be termed "reason."

Locke's position on the use of words to convey ideas is outlined in his Essay. Evidence of the same position can be seen in Willard's writings. In her article entitled "Universal Terms-Dispute Concerning Them and Their Causes," Willard's philosophical connections to Locke become particularly clear. There are three major parallels: how words are used to describe ideas; man's ability to generalize terms for universal communication; and the use of sensory information in the process of idea formation.

\section{Locke's Position}

In his Essay Concerning Human Understanding, Locke attempted to answer certain philosophical questions which had been raised by the Newtonian model of the "clock-work universe." Newton's model was founded on the concept of a scientific universe made up of parts working in orderly 
precision. This model was excellent for explaining natural phenomena, but it left unsolved some rather important philosophical questions. These questions John Locke (and his followers) attempted to resolve in a scientific manner. Among the more important of these questions were those concerning man's ability to reason and to acquire knowledge; what might be called man's ability to learn. How do our perceptions of the world reflect reality? How do ideas come about? How do we connect these ideas together to form logical arguments? Finally, how are words used to communicate ideas and arguments to others? These questions were seen as fundamental to any definition of what made men (or women) "rational" beings.

Locke began his work by defining an "idea" as an object of thought. Ideas, he proposed, come from two sources-sensation and reflection. According to Locke, there are no innate ideas, no other organs of perception.

As to the first source, "ideas of sensation," Locke meant that human beings derive certain perceptions about the physical world through the use of the five bodily senses. Mankind's understanding of "reality" is verified by the information received from these senses--information such as the color, scent, or temperature of an object. At the most basic level, Locke held that these sensory ideas were unable 
to be analyzed and he termed them "simple ideas of sensation."

To explain the sensory source of ideas, Locke fully accepted the Newtonian model, with its implied atomism. In describing how mankind formulates ideas through the use of physical sensation, Locke relied on a scientific or mathematical rationale. According to this argument, the material objects that make up the universe have no inherent properties which human beings can perceive. They are made up of what Locke termed "ultimate particles," and they are, like atoms, much too small to be seen. However, the aggregate of these particles, called "bodies," could produce an effect on human beings. This effect is physical sensation. Reflection, Locke's second source of ideas, is thought generated by the operations of the mind without access to external physical stimuli. Examples of "ideas of reflection" are the cognitive operations such as imaging, believing and willing. At their most basic level, these are also ideas which cannot be analyzed; Locke called them "simple ideas of reflection."

The two great and principle Actions of the Mind, which are most frequently considered. . . are these two: Perception, or Thinking, and Volition, or Willing. The Power of thinking is called Understanding, and the Power of Volition is called the Will, . . .14

14 John Locke, An Essay Concerning Human Understanding, ed., with a Foreward by Peter H. Nidditch, vol. 2 (Oxford: Clarendon Press, 1975), 2-5. 
Thus a "simple idea" (either sensory or reflective) is one which cannot be analyzed into smaller component parts. They are the basic building blocks of thought. In the perception of these simple ideas, Locke contended the human mind is entirely passive. (Unfortunately Locke termed both mental processing and sensory qualities as "simple ideas," and this dual definition was to become a problem for his later disciples.)

Continuing to build his theory of rational thought, Locke held that by placing these "simple ideas" together, the human mind can build "complex ideas." These complex ideas in turn give structure to even broader "general or abstract ideas." To accomplish this level of abstract thinking, the Lockean process required the elimination of those qualities which particularize an object; a general or an abstract idea is an idea of what is common to all members of a class.

Logical reasoning, or what might be called "abstract thought," was, by Locke's definition, the ability to inductively generalize between specifics and then move toward a determination of the commonalities among members of the same class. The specific sensory properties of an object must be separated from the time and place in which it was experienced, in other words, "universalized," in order to become a rational thought. This is the function of words and language. 
Words [Locke wrote] become general by being made signs of general ideas: and ideas become general, by separating them from circumstances of time and place, and any other ideas that may determine them to this or that particular existence. 15

\section{Emma Willard's Interpretation of Locke's Position}

Emma Willard, in her article entitled "Universal TermsDispute Concerning Them and Their Causes, " echoed many of Locke's thoughts about the way in which words convey ideas. 16 In this article, Willard entered the debate between the Conceptualist and the Nominalist schools of philosophy concerning the use of universal terminology in language.

The central question considered in Willard's article was "are ideas or words the objects of our thought, when we employ general terms?"17 when I speak to you of "sheep," or "trees," you understand what I mean. You can envision a physical object. However, when I use terms such as "articles," or "things," does the mind create an image of its own where no physical object corresponds? This is

\section{John Locke, An Essay Concerning Human} Understanding, vol. 2, 16-17. An excellent discussion of Locke's position on the matter of human reasoning and its place in the history of American philosophy is contained in Elizabeth Flower and Murray G. Murphey, "The Impact of Science," chap. in A History of Philosophy in America, (New York: G.P. Putnam and Sons, 1977).

16 Emma Willard, "Universal Terms-Dispute Concerning Them and Their Causes," American Journal of Science and Arts 23 (July 1832): 18-28.

17Willard, Universal Terms, 20. 
essentially a variation of the same central dichotomy noted earlier. Are words reflective of a mental process or a physical sensation? Both positions are inherent in the thoughts of John Locke.

If mankind needs some sort of universal classification scheme with which to communicate his perceptions of reality to his fellow man, are these classifications an artificial invention created by man to reflect his physical perception of reality? Alternately, are general terms a natural result of the mind's ability to cognitively link objects together based upon some sort of experiential understanding of common properties? In other words, does the formation of ideas depend upon the ability of words to have universal meaning free from our own personal experience? Are we active participants in the process, as William James was later to assert, or are we essentially the passive "tabula rasa?" In her article, willard explored the positions held by the most prominent exponents of the school of philosophy known as "Common Sense Realism," men such as Stewart, Reid and Brown who attempted to interpret John Locke's position for the early eighteenth century. The article itself dealt with the debate between Dugald Stewart's contention that all languages, like mathematics, have a universal syntax and a certainty which no experience could possibly bestow, and Thomas Reid's, and later, Dr. Thomas Brown's, position which 
contended that our reason comes from our ability to conceptualize, not merely from sensory data but by abstracting "sameness" from experiences.18 As already noted, both positions were extensions of Locke's thinking. 19 Three main points in this article illustrate that Emma Willard's concept of human rationality was, at least in part, either consciously or unconsciously Lockean in origin. The first parallel point willard argued was that rational men can develop general terms which are universal in nature. Her argument follows Locke's position in a rather straightforward manner.

That man is endowed with a capacity to go on forming classifications more and more general, in one of the most wonderful and useful parts of his nature, contributing

18 "Scottish philosophers tended to read their Locke in rather special ways. Those whose background was chiefly mathematical, e.g. Dugald Stewart, were impressed by the universal elements in the human constitution. . . . Those, on the other hand, who were trained in the natural sciences, especially those familiar with psychology and medicine, e.g. Reid and Brown, tended to view Locke as the physician who was looking for the scientific basis of knowledge, . . . "Flower and Murphey, A History of Rhilosophy in America, 239.

19 Brown was concerned with the narrowness of the Lockean sensory explanation of mankind's reasoning process. Even Reid's contention that we must look "at the association of ideas" when mankind builds thoughts, did not go far enough. Anticipating William James and others, Brown gave much more importance to what he called "feelings" in the development of abstract ideas. For example, "When the whiteness of untrodden snow causes us to think of 'the innocence of an unpolluted heart', it is not because the two ideas are simply in proximity to one another, but because they both excite a common emotion." Flower and Murphey, $\underline{A}$ History of Philosophy in America, 261. 
perhaps more than any other faculty . . . to the continual advancement of the species. 20

For Willard, it was natural that mankind should strive to develop universal classifications in order to make sense of the world. It was the ability to develop such classifications, in fact, that separated men from animals. Foremost was the ability to perceive material objects and invent names to designate them. Almost as important (in some ways, more important!), was man's ability to conceptualize abstract ideas for which no material objects correspond. Both classifications required universal terms for expression and communication.

Central to Willard's position is the need for a universal classification scheme which would enable the individual to verbalize the information provided by the senses. From this general class, logical conclusions could be drawn about the world. She writes, "how should we ever recognize new objects, as belonging to certain classes, but by their correspondence to our general ideas."21

Second, Emma Willard's thoughts paralleled that of Locke because she believed that words, representing our general ideas, are the mode of communication between like minded (i.e., rational) people. This is how man shares his

20Willard, "Universal Terms," 21.

$21_{\text {Ibid., }} 23$. 
knowledge. She stated that "we perpetually use words in our thoughts, not always because we cannot think without them, but because we perpetually recur to the communication of our thoughts to others." 22 Words were not simply the reflection of physical stimuli, they were also a reflection of our thought processes.

Finally, willard's arguments were based on a firm belief in the sensory acquisition of knowledge. This concept she adapted directly from Locke. Information which allows us to understand our world comes through our physical senses, especially sight. Like Locke, she argued that mankind reasons from the information received in this manner. Unfortunately, the specific nature of exactly how this process takes place in the human mind is rather glossed over in Willard's article. The "process," she concluded, went something like this:

The intellect of man is accommodated to the world around him. It is the external world which, by means of his senses, particularly the sight, comes to be transferred within, and there to have an immaterial being; and it is thus, that we may read out, to our fellow man what we thus perceive, that we have invented language. If things exist in the mind single, men invent words to express them as such; if they are perceived as constituting a sort or kind, then he invents a word expressive of a class. 23

$$
\begin{aligned}
& 22 \text { Ibid., } 22 . \\
& 23 \text { Ibid., } 26 .
\end{aligned}
$$


Whether or not Emma Willard consciously adapted the thoughts of John Locke can, of course, only be inferentially determined in this case. What can be stated, however, is that Emma Willard's definition of what is meant by the term "rational," paralleled that of John Locke and his later followers. That Willard chose to enter the debate at all shows that she accepted a great many of the standard philosophical precepts inherent in the Lockean climate of her day. 24 For early nineteenth century educators such as Emma Willard, both parts of Locke's thought (the sensory acquisition of knowledge and the process of conceptual thought) were to have an impact upon pedagogical theory. Finally, the very existence of this article by Emma Willard is further proof that she had believed that women could formulate rational thought. She would never have entered the discussion if she had not.

${ }^{24}$ Care should be taken to not make the major European philosophers of the Enlightenment into proponents of women's rights. As Linda Kerber has pointed out, writers such as Locke, Montesquieu and most particularly, Rousseau did not assume women should step out of their traditional role as hand maiden to man. The only major philosopher of this period who did have a picture of women as equals to men, was Condorcet. As far as women were concerned, it was left to the Americans to integrate the Enlightenment view of man's individualism with the democratic ideals of the new republic. Linda K. Kerber, "The Republican Mother: Women and the Enlightenment-An American Perspective," American Quarterly 28 (Summer 1976): 187-205. 
Education and the Rational Woman

If Emma Willard believed that women were capable of rational thought, then evidence should show that she designed her educational curriculum for women to reflect that belief. Her writings overwhelmingly illustrate that she did just that.

The course of study she fostered included subjects which were intended to develop logical and disciplined thinking patterns in her female students. Natural philosophy and moral philosophy made up an important part of Willard's curriculum for women. By requiring her students to ponder the great philosophical questions of the ages, she felt that they not only learned virtue, but developed a "mental tightness." "It is highly important [she wrote in her Plan for Improving Female Education] that females should be conversant with those studies which will lead them to understand the operations of the human mind." 25

A wide variety of scientific subjects came to be, along with mathematics, the cornerstone of Willard's advanced curriculum for her rational women. The School catalogue from her Troy Female Seminary for the school year 1843-44 lists

25Willard, Plan for Improxing Female Education, 14. It is also possible that Willard's emphasis on the study of philosophy, what she terms "the operations of the human mind," (and what might today be called psychology) may have been reflective of the general, growing interest of scholars, clergymen, physicians and others of the time in the emotional and/or the subconscious processes of the mind. 
courses in botany, geology, geography, astronomy, chemistry, algebra, mechanics, and geometry.26

Over the decades, as her pupils studied mathematics and science, Emma Willard was provided with proof that women could develop into reasoning creatures. Increasingly, as the years went on, her students were required to complete a course of study heavily weighted toward what would be termed the "solid subjects." By requiring her students to successfully embrace scientific thinking, as it was reflected in the design of her own school's curriculum, willard continued to enhance her own faith in the ability of education to develop rational women. Years later, when giving advice to a group of young teachers, she said, You can also see that the mark to be aimed at in the intellectual education of your own pupils. . . is to give intellectual ability; to perfect that power of the human mind which enables it to search after truth, to find it, and to know when it is found. Hence the value I attach to mathematical and philosophical studies. 27

26 Catalogue of the officers and Pupils of the Troy Female Seminary for the Academic Year, Commencing March 8 , 1843, and Ending February 21, 1844; together with the conditions of admittance, \&c (Troy: N. Tuttle, 1844), 14. Also included in the catalogue is the entry which states that "Extensive Courses of Lectures are annually delivered by Professors on Chemistry, Natural Philosophy, Geology, Botany, Astronomy, Physiology, and Elocution.", Catalogue, 15.

27 Emma Willard, Letter Addressed as a Circular to the Members of the Willard Association, for the Mutual Improvement of Eemale Teachers (Troy: Elias Gates, 1838), 8. For an interesting feminist perspective on the development of women's educational curricula and the debate on women's rationality in Britain prior to this period see, Veena $P$. 
Emma Willard's philosophical position defined women as rational beings who, like their male counterparts, were a product of the scientific tradition established by Locke and other Enlightenment philosophers. Thus the education of women, the product of that tradition, both could and should center upon method, reason and logic.

Along with many educators of her time, willard believed that the student was in fact John Locke's "tabula rasa." Like a soft wax tablet, the mind of the student could be "given intellectual ability" by the vigorous practice of philosophical argument and arithmetic calculation. The human mind could be trained to think rationally.

In designing the curriculum for her female students Willard's educational biases were incorporated into course work which stressed deductive and inductive reasoning, philosophical "gymnastics" and mathematical precision. It was as educated people that these women were to become natural instructors of children.

\section{Woman as Teacher to the child}

Mothers, [wrote Emma Willard in 1865]. . . stand at the very fountain of influence. The dress, manners, books,

Kasbekar, "Power Over Themselves: The Controversy About Female Education in England, 1660-1820" (Ph.D. diss., University of Cincinnati, 1980). Kasbekar asserts that women's education empowered them in many other ways besides academia, a thought that Emma Willard would have agreed with in principle. 
regularity and punctuality of attendance, and the review or preparation of school lessons at home, of the children [sic], depend mainly upon them. 28

Throughout her life, Willard believed in a fundamental, unique and sacrosanct bond between mother and child. This bonding process was the underlying reason that she felt so strongly about creating a central role for mothers in the education of their children. Much of this viewpoint she had learned from observing her own mother, as has been noted earlier in this paper. In this belief, however, Emma Willard also mirrored thinking which had come to be almost universally accepted in mid-nineteenth century America.

After many years of being held in disrepute, several cultural, social and religious trends converged, particularly in the years between 1830 and 1860 , to produce a new acceptance of "motherhood."29 Even as these influences combined to redefine what the relationship between mother and

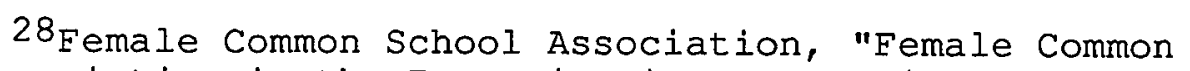
School Association in the East District of Kensington, Connecticut," American Journal of Education 15, (November 1865): 612. This article includes a rather lengthy quotation of a letter from Emma Willard.

${ }^{29}$ This poor image of motherhood was also echoed in the reading materials of the day, as Ruth $H$. Bloch has noted. "in seventeenth and late eighteenth century literature written and read in America, motherhood was singularly unidealized, usually disregarded as a subject and even at times actually denigrated." Ruth H. Bloch, "American Feminism, Ideals in Transition: The Rise of the Moral Mother, 1785-1815," Feminist Studies 4 (June 1978): 100-126. The Romantic version of motherhood which followed is reviewed in Barbara Welter, "The Cult of True Womanhood: 1820-1860," American Quarterly 28, (Summer 1966): 149-74. 
child would be, there was a growing gap between the economic reality of industrial-age family life and the ideological "fiction" which came to glorify the concept of the "fragile, tender-hearted mother." In her thoughts on education, Emma Willard reflected most of the "fiction" and a good deal of the reality.

A major influence, fundamental in redefining the mother and child relationship, was the changing economic situation of early nineteenth century America (primarily New England). The disruption of family life brought about by increasing urbanization and industrialization in towns caused a restructuring of the traditional family unit. Consequently, a change occurred in the link between husband and wife, and mother and child.

One of the most important forces which contributed to the weakening of family relationships was the very nature of the modern, industrial, economic progress. New, mechanized factories, which literally destroyed many of the basic values of colonial American life, resulted in a diminished role for the individual and an overall lessening of "selfhood." The result was a sort of ideological "schizophrenia" between the older traditional values and the new material society. While an abhorrence of the evils of material wealth may have been expressed by some, by mid-century there was a general acceptance that prosperity and progress were "good" 
things. A growing push for upward mobility and the desire for greater social status had their impact upon the family. A new type of family structure came into being, one in which the father now left to work in a factory or business. This action caused the management of the family to fall on the shoulders of an often ill-equipped or immature wife. 30

The lower middle classes generally lacked the financial resources for maids or other domestic help. Forced to economize within the home in order to keep up outward social appearances, wives in these economic classes were often thrown into very close and almost continual contact with their children. Many upper class women farmed out their children to nannies and looked upon the youngsters as burdens or "pretty playthings." In both instances the relationship between mother and child was often one of emotional turmoil, physical mismanagement, neglect, and periodic abuse.

Finally, the traditional family unit weakened under the growing indifference with which these worldly parents now regarded their religious duties. The old habits of saying

30 As Anne L. Kuhn has pointed out in her landmark study of the mother's role in early nineteenth century New England, many young women were married off very early for both economic and social reasons. The consequences of early marriage and motherhood were poor health, high maternal death rates and a growing belief in the "fragility" of women. As the nineteenth century progressed this image gradually broke down under reforming pressures. Anne L. Kuhn, The Mother's Role in Childhood Education: New England Concepts, 1830-1860 (New Haven: Yale University Press, 1947). 
grace at meals, the daily reading of the Bible, and morning and evening prayer sessions (all usually conducted by the father of the family) began to break down under the pressures of a culture which increasingly emphasized material goods, scientific progress, and the amassing of wealth. 31

Partially as a result of these changes, the purpose of education and the very nature of childhood started undergoing a vast ideological reevaluation. The old view of a child's stature and destiny, at least partially rooted in America's Puritan heritage, came under attack. That heritage, as David Stannard has pointed out, was not a very good one. In his book, The Puritan Way of Death: A Study in Religion, Culture and Social change, Stannard describes the view that many Americans of the early nineteenth century still held concerning the nature of childhood. To the most conservative of these,

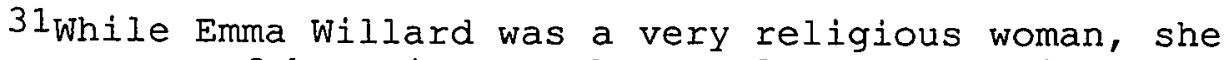
was also a person of her times. She rarely saw any discord between the basic tenets of Christian piety and the fundamental values of economic progress. Her ability to see economic betterment as the outcome of God's special relationship with America is once again founded on the Lockean belief in the sanctity of man's divine right to property. Indeed, she devotes an entire chapter in her book Morals for the Young to the "natural right to property," civil authority's duty protect to it, and God's divine sanction of it. See Emma Willard, "The Decalogue: Relative and Reciprocal Duties," chap. in Morals for the Young; or, Good Principles Instilling Wisdom (New York: A.S. Barnes and Co., 1857), 126-30. 
the Puritan child was riddled with sin and corruption, a depraved being polluted with the residue of Adam's sin. If there was any chance of an individual child's salvation, it was not a very good chance-. . . .32

With the onset of the era known as the "Romantic Movement," new perspectives began to undercut this picture of children as lost, depraved souls. The Romantics clearly rejected the Puritan view of the sinful child. In their view, the child was innocent and pure. In its sentimentalized form, Romanticism idealized the child. Poems such as "The Little Hand," by Lydia Sigourney stressed the untainted physical beauty of the infant, and mothers were admonished to rejoice in this verification of God's work.33

Along with the economic forces which were reshaping the American family, the Romantic spirit, (and in particular its American version, Transcendentalism), began to produce a new vision of the child and its relationship to the mother. 34 This new relationship was loving, nurturing and bonding.

32David E. Stannard, The Puritan way of Death: A Study in Religion, Culture and Social Change (Oxford: Oxford University Press, 1977), 49. Interestingly, Stannard also mentions a man named Samuel willard as the author of a child's book entitled The Child's Portion (Boston, 1648). As Emma Willard's husband's family was a prominent Puritan family, it is very possible that there is a family connection here.

33Lydia Sigourney, "The Little Hand," Parent's
Magazine (December 1840):71.

${ }^{34}$ Transcendentalism was in part a reaction to the bleak picture that the Puritans had painted; but in part it also made democratically possible three main tenets which had been accepted in the more restrained thought of New England 
The Romantics tended, therefore, to regard the education of chilaren in a critically different way. The mother came to be seen as the "natural" first teacher of the child because of the bond that united her with her child. While in its more extravagant forms the Romantics did tend to sentimentalize the child all out of reality, both Romanticism in the main and its American derivative, Transcendentalism, made several important contributions to the advancement of educational theory. 35 The most important aspect of this was a new recognition of the importance of the child. In contrast to the more conservative point of view, the child was now seen as a unique, separate individual. He or she was no longer a corrupted, and sinful "miniature adult," but a future economic producer, a malleable mind to be

for quite some time. These three tenets were the concept of the free individual, perfectibility of the individual and the socially responsible individual. It is ironic that this renewed emphasis on individualism should appear at the very time men (and women) were losing their individuality in the factories.

35 one of the most significant of the Transcendentalist educators was Amos Bronson Alcott. Alcott and many of his colleagues were frequent contributors to Henry Barnard's American Journal of Education. As Barnard was a close collaborator with Emma Willard in the establishment of the Connecticut Common School program, it is not surprising that Emma Willard's views on education should parallel the Transcendentalists thoughts in many ways. For a discussion of Emma Willard and Henry Barnard see "Work with Henry Barnard in the Common Schools of Connecticut," chap. in Lutz, Emma Willard, Daughter of Democracy (Boston: Houghton Mifflin Company, 1929). 
fashioned in a democratic way, a participant in the great march of scientific progress, or as a potential member of the evangelical church. However, this unformed child was particularly in need of early moral guidance and discipline. By virtue of her nature, this guiding role was assigned to the child's mother.

In this argument, that the mother is the natural teacher of the child, several main concepts were finally blended together: the Enlightenment faith in the ability of education to lead to personal and social progress; the harsh realities of industrial production which reduced the child to a potential economic producer; and the Romantic vision of the child as an innocent in need of guidance. 36

The typical mid-nineteenth century New England view of childhood skillfully combined John Locke's concept of tabula rasa, the traditional Puritan belief in personal sin, and the new Romantic belief that the child was redeemable through

${ }^{36}$ It should be mentioned that aside from the philosophical and religious arguments which placed women in the natural role of teacher, there was also a very sound economic argument. The work of women was always available at less cost. This fact was to prove a problem for women who entered the teaching profession in the later part of the nineteenth century. It was also a problem which Emma Willard devoted much of her activity toward rectifying. She constantly advocated paying female teachers what they were worth. See for example Willard, Ietter Addressed as a Circular to the Members of the Willard Association for the Mutual Improvement of Female Teachers, 6; also see, a letter by Emma Willard, "Proposed Plan of Improvement," Connecticut Common School Journal 2 (April 1840): 243. 
careful maternal instruction. 37 According to Anne L. Kuhn, the compromise was this: "the child is born with a blank mind and is a potential inheritor of heaven or hell. He is not a moral agent, but he fast becomes one, and the parent is supremely responsible for imprinting pure images on the waxen tablet of his mind."38

\section{Emma Willard's View of the Mother as Teacher}

In her thoughts on education, Willard reflected a compromise between the Romantics and the Lockean empiricists, between the orthodox views of the church and romantic liberalism. She did this by combining faith in the divinely ordained ability of the mother to transmit virtue and morals to her child, with the rational mediums of science and education.

${ }^{37}$ The impact of the religious movement known as "The Great Awakening" which hit New England in midcentury, with its emphasis on spiritual rebirth and millennialism should not be underestimated. It was the link between the rationalism of the eighteenth century and the romanticism of the nineteenth. It had significant consequences for America's view of childhood and education. This aspect of Emma Willard's thought will be dealt with in a later chapter of this thesis. An interesting article which deals with the later fallout from this mass spiritual awakening is Anne $M$. Boylan "Evangelical Womanhood in the Nineteenth Century: The Role of Women in Sunday Schools," Feminist Studies 4 (October 1978): $62-80$.

21.

38 Kuhn, The Mother's Role in Childhood Education, 
First, Emma Willard took as gospel the argument that there was a strong biological and psychological bond between a mother and her young child. She constantly returns to this theme throughout her life.

That Nature designed for our sex the care of children she has made manifest by mental as well as physical indications. She has given us, in a greater degree than men, the gentle arts of insinuation, to soften their minds, and fit them to receive impressions; a greater quickness of invention, to vary modes of teaching to different dispositions, and more patience to make repeated efforts. 39

Later, in an article entitled "A Treatise on the Motive Powers Which Produce the Circulation of the Blood, "Willard quoted an essay in the Educator which maintained that, "the physical and moral tendencies are generally communicated or excited before the child passes from the sphere of the mother's influences." 40

Second, Willard acknowledged the potentially sinful nature of childhood which was the heritage of her New England Puritan genealogy. In speaking of the Puritans Willard said, [their] leading qualities were those which every parent acknowledges, in the training of his child, are not only

\footnotetext{
39Willard, An Address to the Public: Particularly to the Legislature of New York, Proposing a Plan for the Improvement of Female Education, 22. Again it is interesting to note the Lockean vision of the child's mind as a wax tablet which the teacher can "soften" to "receive impressions."

40 Emma Willard, Treatise on the Motive Powers which Produce the Circulation of the Blood (New York: Wiley and Putnam, 1844), 170.
} 
great and good, in themselves, but they are safeguards from vice, and the prime foundations of every virtue. These, were the love of God, sincerity of speech and action-and a stern adherence to the dictates of conscience [emphasis mine]. 41

That there was a possibility that children might slip into moral depravity without the gentle, guiding hand of their parents (in particular their mothers), Emma Willard never doubted.

Third, Willard also acknowledged that the main goal of education was to instill certain moral values in the pliable conscience of the child.42 To send the child off in the right direction as a "seeker of truth and virtue," bestowed upon the mother great power and responsibility. As the child was "a blank slate," mothers had the ability to either impress the principles of "right thinking" upon the child's mind or lead him down the path to moral perdition. 43 It

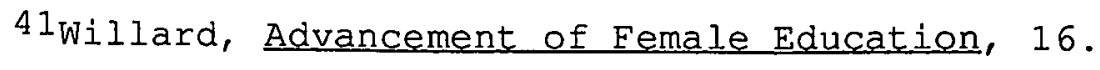

42 "Yet, in the culture of the mind, intellectual improvement should ever be held as secondary to moral." Emma Willard, Geography for Beginners: or the Instructor's Assistant, in Giving First Lessons from Maps, in the style of Eamiliar Conversation, (Hartford: Oliver D. Cooke and Co., 1826), vii.

43 In her work, Morals for the Young, willard used a rather innovative (for the times) instructional. method in order to illustrate that the child had two paths to choose from in life. The frontispiece of the book contains a picture of an actual path, divided into two trails. One trail leads through folly, falsehood and delusion to end up in "Destruction;" while the other trail leads through wisdom, fear of God, faith, truth and duty and ends up in "Eternal Life." Emma Willard would often use visual aids in the design of her instructional materials, as she had a firm
} 
followed, therefore, that since this new definition of

motherhood required women to be their child's moral

instructors, women needed proper education. In her Rlan for

Impreving Female Education, Willard asked

Unprovided with the means of acquiring that knowledge which flows liberally to the other sex-having our education devoted to frivolous acquirements-how should we understand the nature of the mind, so as to be aware of the importance of those early impressions which we make upon the minds of our children? or how should we be able to form enlarged and correct views either of the character to which we ought to mould them, or of the means most proper to form them aright? [emphasis mine] 44

Willard also noted the important connection between physical health and mental ability for both mother and child. As the guardian of their child's total well-being, mothers needed to be mindful that a sick or undernourished child would not be able to take full advantage of the education provided. As guardians of the kitchen, women had an obligation to provide a healthful atmosphere for their child's development and learning.

In expressing these beliefs, willard mirrored much of the thoughts of the social reformers of her day. Throughout the nineteenth century the push for domestic reform

belief in the Lockean concept of learning through sensual perception. Emma Willard, Morals for the Young, Frontispiece.

44 Willard, An Address to the Public; Particularly to the Members of the Legislature of New York, Proposing a Plan for Improving Female Education, 2 . 
intensified as more and more people became convinced that good food, clean houses, regular physical exercise and plenty of fresh air were critical for the full development of the child. Morally it became important to glorify the body as the "temple of the soul." New attitudes pointed to the interdependent functioning of the body, the mind and the soul.

While the name most often associated with domestic reform is Catharine Beecher, 45 Emma Willard was also instrumental in promoting women's role in this area. As early as 1819 willard included domestic instruction as one of the cornerstones of her Plan for Improving Female Education. "It is the duty of our sex to regulate the internal concerns of every family. . . . It is believed that housewifery might be greatly improved by being taught, not only in theory, but in practice."46 Willard's most prominent biographer felt that suggestions such as these should have earned willard the

45 The classic on the subject is Catharine Beecher, $\underline{A}$ Treatise on Domestic Economy, Rev. ed. (Boston: Thomas A. Webb and Co., 1842). While both Willard and Beecher were reformers in the field of women's education, Emma Willard was not able to join Miss Beecher in her quest for women's rights.

46 Willard, An Address to the Public: Particularly to the Members of the Legislature of New York, Proposing a Plan for the Improvement of Female Education, 15-16. 
title of the "originator of Domestic Science in girls" schools." 47

Finally, as teachers to their children, Emma willard felt that women played an important part in society. In raising the future citizens of the new republic, women also exerted a special influence in the area of education. While she never argued that women should move out of their appointed sphere, Willard did believe that women, as the moral voice of society, had a specific role to play in the education of these future citizens.

\section{The Social Position of the Educated Woman}

During Emma Willard's lifetime, the definition of what a woman's primary function should be in a democratic society underwent a dramatic change. The conflict was not truly about female submission or freedom, per se. The debate really raged between those truly militant feminists who felt the need to make a total break with the old order and those who felt that true "emancipation" came gradually from the vocation of being wife and mother.

The "professionalization" of motherhood by women such as Catharine Beecher led some reformers to emphasize women's social responsibilities rather than rights. These gradualists tended to see women's true power in their ability

47Lutz, Emma Willard, Daughter of Democracy, 71. 
to successfully mold the minds of the rising generations. They emphasized domestic reform and maternal education of the children. Rather than using radical actions which would alienate the rest of society, both male and female, these progressive reformers maintained that women were not really equal to men. They did contend, however, that woman should occupy a separate "sphere of influence" within which she reigned supreme. This separate sphere required that women take up their social responsibility as the moral voice of American democracy.

Biologically and psychologically suited for this purpose by nature, so the argument ran, women provided the "nurturing" which society needed. Just as women were temperamentally suited to rule the nursery with a firm but gentle authority, those subscribing to this "middle position" concerning women's place, believed that women were best suited to be the moral agent of a free and democratic state. Women's virtuous behavior, it was felt, provided a counterbalance to the corrupting effects of business, urbanization, materialism and industrialization noted earlier.

Due to a variety of factors, primarily increased opportunities for women in business, this view of women's societal role began to break down as the nineteenth century 
progressed. 48 But it is, in the main, the point of view Willard held throughout her lifetime, and it affected the way in which she viewed the role of women in education. Written evidence that Emma Willard was not a militant feminist is plentiful. Women, she held, were not the equal of men. In 1819, her Plan for Improving Female Education stated that "I would not be understood that we are not, in particular situations, to yield obedience to the other sex." She then went on to say that, "Whenever one class of human beings derive from another the benefit of support and protection, they must pay its equivalent-obedience."49 In 1848 she again wrote, "The husband, the father and the master is here [in the family], a natural sovereign. Woman, as wife, is the chief subject of his domain. . . Let each sex then keep its own place."50 Even toward the end of her life she had not changed this basic tenet, "Were a grand family procession to set forth in the order appointed by Providence,

${ }^{48}$ Concerning the business careers open to women in the nineteenth century see, Elizabeth Anthony Dexter, Career Women of America, 1776-1840, (Francestown, New Hampshire: Marshall-Jones Co., 1950).

49 Willard, Address to the Public: Particularly to the Members of the Legislature of New York, Proposing a Plan for Improving Female Education, 8.

50 Willard, Letter to Dupont de l'Eure on the Political Position of women, 8-9. 
the white men would go first, the white women with their children second, . . ."51

But Emma Willard did not mean that women should have no rights or influence at all. Her argument was rather more ingenious and complicated. First she believed, like other progressives, that women occupied a separate sphere and that sphere was primarily domestic.

So man must provide for his family, while his wife with his children remains at home. It is suitable then, that the means of the family, so far as this object is concerned, should be at his disposal. On the other hand, to the direction of the female head of the family, should be assigned such a portion of the family income as can be afforded for her own personal accommodation and that of the little children. 52

If women were subordinate to men and if they were naturally responsible for the well-being of the household, Emma Willard argued that women also had responsibilities to "the great national household."53 In other words, women had a positive duty to "nurture" the democratic state. She proceeded to spell out specifically what these duties were:

51Emma Willard, Via Media: A Peaceful and Permanent Settlement of the Slavery Ouestion (Washington: Charles $H$. Polkinhorn, Printer, 1862), 3 .

52 Willard, Letter to Dupont de l'Eure on the Political position of Women, 13.

53 Ibid. 
1. The care of the schools for young children; in respect to their religious, moral and intellectual training-a work for which the God of nature has fitted [women]. 2. The care of the poor.

3. The care of public morals, especially in so far as their own sex are concerned.

4. Direction of female education beyond the primary schools. 54

Emma Willard saw the public duty of women as guardians of social morality. Since almost everyone believed that the main goal of education was the creation of a moral society, Willard's argument was palatable to much of America's mainstream. It was the very "middleness" of her philosophy which increased her effectiveness.

Thus, an attempt to make Emma Willard into a militant feminist, is to misinterpret her entirely. Willard's very effectiveness, as Anne Scott has shown, lay in her ability to influence from within the system. 55 After willard's death, her sister, Almira Lincoln Phelps, stated that,

\section{Ibid.}

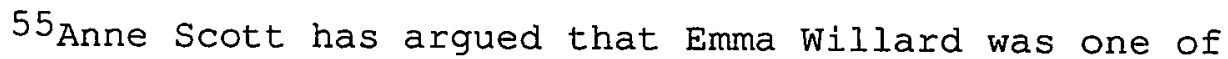
the first Americans to speak publicly about women's "rights," a position which gives willard a feminism she might not merit. What scott has pointed out is that Emma Willard might be called a feminist in the modern sense if we look at her actions as being more important than her writings; which are often contradictory. It is as an example to others who followed that Willard's enduring influence comes. Anne Firor Scott, "What, Then, is the American: This New Woman?" Journal of American History 65 (December 1978): 679-703; "The Ever Widening Circle"; "Emma Willard: Feminist," Commencement address to the graduating class at the Emma Willard School, May 10, 1978. Typescript copy, Emma Willard School Archives, Troy, New York. 
"Emma Willard may have seemed to have stepped out of the province of women. . . . [however] she had no sympathy with the declaimers upon women's rights; those who advocate the mingling of women in political strife, or who would change the order of God's providence in fixing her condition in social and domestic life."56

Willard was content to stay respectable, but only just barely.

\section{Women's Social Sphere and Education}

The question next arises: If Emma Willard saw a rather narrow public role for women, how then were women to manage the education of the children? Her answer was to propose that women form "Associations" dedicated to the cause of school improvement. It was through these Associations, which were mainly advisory or influential in nature, that women could successfully fulfill their social and educational responsibilities.

In 1840 Emma Willard joined Henry Barnard and other educators to begin the process of improving the Common Schools of Connecticut. During this time, she also wrote several articles for Barnard's connecticut Common School Journal. In these articles, willard reported on the condition of the Common Schools of Kensington, Connecticut-an area over which she had just been elected superintendent.

56 An Address to the 1870 meeting of the American Association for the Advancement of Science, given by Almira Lincoln Phelps. Story quoted in Lutz, Emma Willard, Daughter of Demecracy, 237. 
(Her election to this position is an interesting action on her part, given her views on women's political rights.)

Emma Willard accepted the position of Superintendent only on the condition that the women of Kensington as well as the men support her work. So adamant was she about the role that women should take in reforming the school system, that she organized a "Female Common School Association." Her address to this group, entitled "The Relation of Females and Mothers to the Cause of Common School Improvement," was printed in Barnard's connecticut Common School Journal (March 1842). The address was widely praised and was even read at the annual meeting of the western College of Teachers in Cincinnati, ohio. 57

In this address, Willard made the case that an Association of mothers was critical for instilling the proper direction and moral tone to local school reform. She argued that the Association was simply an extension of the natural relationship between mother and child. It was "as in a family, [where] no cure on earth be to little children like that of the mother, [and] so to the collected children, none can be equal to that of the collected mothers."58

57Lutz, Emma Willard, Daughter of Democracy, 214-15.

58 Letter by Emma Willard, quoted in "The Relation of Females and Mothers Especially to the Cause of the Common School Improvement," Connecticut Common School Journal 5 (March 1842): 64 . 
Men, Emma Willard argued, "already have the general government in its complicated play to look after, in peace and war." Therefore, men "do not have time to regulate all the minutia connected with the teaching of their little children." 59 So by banding together into "maternal organizations," Willard found a logical way for women to assert the influence that she felt they should in the area of education. This method also fit comfortably with her own personal philosophical outlook concerning the correct position of women in society.

The function of these Associations was to act as "watchdogs" over all aspects of the school's day-to-day operations, including what was taught, how it was taught, who taught it and where it was taught. In this manner the benefits of maternal influence would be felt by all who attended the common Schools. 60

Not only would the children benefit from an overall uplifting of the moral tone, but by actively participating in

\section{${ }^{59}$ Ibid.}

60 In unpublished notes made to her plan for Improving Female Education, Willard also advocated that the governing board of schools for women include female members. "The board of reputable matrons connected in this manner with a female institution is a guarantee to the public that no regulation will be adopted or practice prevail inconsistent with female propriety." Typescript copy of handwritten notes by Emma Willard, n.d., Archives of the Emma Willard School Library, Troy, New York. 
the education of their children, women would "improve not only their daughters but themselves." Each mother and daughter would learn from the experiences and their time would be profitably spent. She provided an example of how the mothers of a school Association were helpful in the academic examination process of their daughters. She wrote, "Instead of gay parties for their daughters [the Association's members] have in some cases invited a class it may be of geometry or chemistry to their house, and examined them in their study." 61

The influence of women upon the lives of their children, especially their daughters, was fundamental to Emma Willard's philosophy of education. As individuals, mothers, or members of a "Female Association," Willard saw well-educated women as pivotal in creating America's moral citizen. The future of the nation depended upon them.

"Our Common School system must be regenerated or our country is undone, . . ." she warned.62 By educating the future citizens of the United States, Willard's educational philosophy blended a strong personal patriotism with a vision of the place of America's women in a modern, industrialized world. The result was her call for the improvement of women's education.

$$
\begin{aligned}
& 61_{\text {Ibid. }, ~} 65 . \\
& 62 \text { Ibid., } 64 .
\end{aligned}
$$


CHAPTER THREE EMMA WILLARD'S EDUCATIONAL PHILOSORHY:
EDUCATION AND THE PATRIOTIC CITIZEN

A little over two hundred years ago, in May of 1787, several dozen delegates--all of them men, all of them white, all of them property owning members of the political establishment--met together in the State House in Philadelphia and proceeded to write the Constitution of the United States. This document, along with the Declaration of Independence, served to enshrine the values that the new country held most dear. Based upon certain liberal philosophical principles, it was the foundation for the nation's governing institutions.

In February of that same year, Emma Willard was born in Berlin, Connecticut. She was, as we all are, a product of her era. The world in which she lived was one of order, community and continuity, but by the time her life ended in April of 1870, Emma Willard's world had changed dramatically. Industrialization, urbanization and immigration had reshaped the economic and social order of the United States, and correspondingly, some of its attitudes toward education.

Economic factors, once again, were at the forefront of this change. The North was in the process of shifting from a 
predominantly mercantile economy to one based on industry. The South, which had been increasingly dominated by cotton production until its defeat in the Civil War, had also begun to industrialize. It appeared that the entire "civilized" world was rushing to embrace the new prosperity of the Industrial Age.

Most significantly, this rapid economic prosperity affected the country's class structure, causing it to undergo a metamorphosis. Industrialization and urbanization created a social mobility that few people living on American farms at the turn of the century would have believed. As the nineteenth century unfolded, the stability and permanency of the agrarian way of life quickly became a cherished national memory .

As a barometer of this social change, the country's educational system was influenced to a startling degree. With the development of a new, middle class morality that clashed with old agrarian values, working class demands for a bigger "slice of the pie," and the ascendancy of a fabulously wealthy American aristocracy, educators were presented with an interesting ideological situation. How could they blend traditional ideology with a new, industrial reality? Moreover, it seemed obvious to everyone concerned that these same changes, when coupled with America's religious heritage and the impact of the Westward expansion, would substantially 
influence what educators chose to teach their students and how they went about doing it.

Patriotic educators like Emma Willard taught their students that the United States, the home of virtue as well as freedom, would enviably be the greatest economic power in the world. Their faith in America's divine mission required a corresponding social and philosophical justification; thus the inculcation of patriotic values became part of the process of defining our country's character.

The tricky job of blending the liberal philosophical sentiments of the Founding Fathers and the religious heritage of our Puritan forbears with the new economic realities of industrialization fell to the teachers, educational thinkers and writers of school textbooks during the nineteenth century. Through their words, both written and spoken, educators began codifying America's cultural values.

Part of their task, as they saw it, was to determine answers to specific moral questions: what would come to be considered "right" and "wrong" by large portions of American society. They accomplished this task with surprising unanimity. In reviewing the works of early nineteenth century educators, it becomes clear that the authors provided the public with fairly consistent moral messages. Certain assumptions about the way the world was, the way it should be, and the way it would be, if everyone marched to the same 
tune, permeated the lessons of American school children of the period.

Not surprisingly, Emma Willard's writings reflect almost every one of these basic assumptions. The development of an educated, virtuous, hard working, God-fearing American citizen (male or female) was Willard's goal. In her textbooks, speeches and other writings she mirrored those values which were central to the building of America. This chapter will explore those patriotic values which were at the core of Emma Willard's personality and will show how she translated these values into her educational philosophy. Obviously, the role of education in this new, democratic republic was important to Willard, and because of her position these same values had consequences far beyond her immediate circle. As one author has noted, "Willard's effect was far reaching because of her textbooks and their wide use, and because of the quantity and quality of young women trained at the Troy Female Seminary."I

\section{America's Philosophical Heritage}

In order to understand the role that Emma willard felt education was destined to play in the shaping of America, it is necessary to first look at the formative influences which

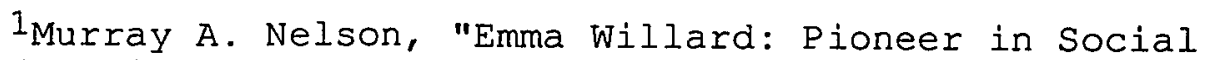
Studies Education," Theory and Research in Social Education 15 (Fall 1987): 255. 
were her inheritance. The values that Americans decided were important enough to shape the curriculum of their children did not spring up newly formed after the Revolution. Philosophically they were part of America's ties to Europe, particularly the eighteenth century and the Enlightenment. Among those values were an unswerving faith in the perfectibility of man and his institutions; the certainty of man's ability to determine, chart and control his progress through the development of flexible institutions; and finally, a fundamental appreciation of education as the principal means of progress. Mankind, it was felt, could be changed for the better through education.

The experience of the Revolution contributed other philosophical principles which affected the development of American education. Although they had common roots, America and Britain were viewed as distinctly separate nations; America now had a charter upon which to build its own governing institutions.

The design of these institutions was based upon one of the most important underlying philosophical concepts of the English Enlightenment: Locke's theory of property. But it was a peculiarly American interpretation of Locke's thought which had the greatest impact. Emphasizing the importance of the individual and his right to own property, the American basis of government was translated by the Founding Fathers 
into rule by the "sovereign people." Thomas Jefferson

replaced the Lockean precepts of life, liberty and property, with the "inalienable rights" of life, liberty and happiness. Many historians have argued that Jefferson's action represented a significant shift in ideology. 2 The result was a government responsive to the will of the people. America was to be the great experiment in the application of enlightened principles. Drawing upon a tradition which began with Plato, America's leaders believed only a well-educated citizenry could weather the difficulties that were sure to beset the new republic. 3 A supposedly open, mobile and democratic society required citizens who were aware of their responsibilities and capable of fulfilling the roles America demanded of them.

2 That the American reader was touched by the European Enlightenment there can be no doubt. After the Revolution, books provided the primary and most enduring way of communicating these Enlightened beliefs to educated Americans. In their study of the libraries of American readers, David Lundberg and Henry F. May found that, "One notices also the continuing hold in America, throughout the century and after, of such traditional, sedate and respectable works as Locke's Essay, Rollin's Ancient History and the critical works of Lord Kames." David Lundberg and Henry F. May, "The Enlightened Reader in America," American Quarterly 28 (Summer 1976): 271.

3 "So striking is the part played in Plato's ideal state by education that some have considered this to be the chief topic of the Republic. Rousseau said that the book was hardly a political work at all, but was the greatest work on education ever written." George Sabine, "Plato: The Republic," chap. in A History of Political Theory, 3rd ed., (New York: Holt, Rinehart and Winston, 1961), 59. 
The chief social institution which would permanently determine the thought of the emerging nation and assist in fashioning its institutions in harmony with liberal principles was the educational system. It was felt that a strong system of national education would promote a national culture, a natural expression of these liberal beliefs. As Thomas Jefferson noted, the purpose of the institution of education was to "instruct the mass of our citizens in these their rights, interests and duties, as men and as citizens."4

\section{A Call for National Education}

Planners for a national system of education divided into two major factions. The first faction delineated a narrow, rigid system of indoctrination in those values which were determined to be peculiarly characteristic of America. The second faction adopted a view which stressed the development of a "scientific" attitude toward education. The latter believed that human progress had to be the result of open minded contributions from all sorts of sources: objective and unbiased.

Both factions were nationalistic in their belief that for the first time, a nation existed that could deliberately

\footnotetext{
${ }^{4}$ Quoted in Linda $\mathrm{K}$. Kerber, "Education and Intellect," Women of the Republic; Intellect and Ideology in Revolutionary America, Institute of Early American History and Culture (Williamsburg: University of North Carolina Press, 1980), 189.
} 
create an educational institution that was both humanitarian and democratic. 5 That this new educational experience would be uniquely American, writers such as Benjamin Rush, Robert Coram, James Sullivan, Nathanial Chipman, Samuel Knox, and particularly Noah Webster, never doubted.

With its emphasis on individual rights and democratic principles, American education would overcome the narrow boundaries of nationality, class and geography which characterized the educational systems of Europe. In the free and open society of the United States, educational principles could be "scientifically" applied. Further, it was felt that the pioneering experience born from the rapid expansion of the country, gave all America's people a common outlook on life and thus a common set of practical ideals. So it was agreed that Americans must be educated. The liberal principles upon which the country was founded needed to be instilled in the minds of its young citizens. The role of governmental institutions was to provide some system of

\section{In his discussion of this concept of man as a} progressive being, Allen Oscar Hansen notes, "The doctrine of the indefinite perfectibility of man and of institutions was defined and its implications elaborated in the eighteenth century. The idea that man was progressive by nature stimulated an analysis of the conditions that govern progress. . . . The institutions that prevailed were in general obsolete and had been the result of chance and superstition. Institutions could be justified if they contributed to the advancement and welfare of mankind." Allen Oscar Hansen, Liberalism and American Education in the Eighteenth Century (New York: Octagon Books, 1977), 20-21. 
national education that would assist in building a new American culture.

\section{The Impact of Nineteenth Century Progress}

As the nineteenth century progressed, four main influences began to drive a wedge between the values early America held dear and the reality of everyday life. One of

these influences, the effect of America's growing industrial might, has already been noted. But social and philosophical forces were also busy reshaping the United States, and educators struggled to incorporate the new ideas spawned by these forces into the materials which they taught their students.

By the 1790 s many conservatives in America were becoming alarmed at the more radical ideas which the French Revolution had put in motion. The problem, as many of these Americans saw it, was how to save the democratic ideals of the Revolution without advocating a corresponding leveling in the economic and social structures of the country. 6

The "American Enlightenment" attempted to answer this problem by making governmental and social institutions the

6 "For the Revolution was a social movement only in a special sense. It did not flow from deep sources of social discontent, and its aims were not to recast the ordering of society that had developed in the earlier years." Bernard Bailyn, Education and the Forming of American Society: Needs and Opportunities for Study (New York: Vintage Books, 1960), 45 . 
protectors of (respectable) liberal values. In his work on the American Enlightenment, D. H. Meyer points out that "the solution to the problem clearly was not to violate the ethics of the Enlightenment by overtly suppressing ideas . . but to use such free institutions as religion and education to protect faith and morals and to save Enlightenment thought from its own excesses."7 Americans were not ready to follow the French to the more radical consequences of "democratic" thought.

The second influence was the growth of the Romantic movement. The Romantic era was essentially a reaction against the emotional sterility of the previous century. The favorite mode of the previous decades, usually called the "Age of Reason", had been logical thinking and rational simplification. The "clock-work universe" of its chief spokesperson, Sir Isaac Newton, served as a model for both social and scientific analysis. For the followers of rationalist philosophy, the world consisted of a few intelligible parts that worked smoothly together and which could be readily understood by any unprejudiced observer. This cold analysis, however, led many philosophers to abstraction and finally to skepticism. Scientific logic had

${ }^{7 D}$. H. Meyer, "The Uniqueness of the American Enlightenment," American Quarterly 2 (Summer 1976): 181. 
reduced life to a dry business: a set of simple geometric theorems.

The growth of skepticism also fostered a belief that, by using only rationalist thought to define the world, man's deeper self had begun to suffer a starvation of the feelings. Trusting individual experience, the Romanticist began to turn inward in search of answers to philosophical, moral and ethical questions. Looking within himself, the Romanticist returned to his emotional nature and personal experience to redefine "reality" in terms other than scientific. In keeping with his view of man as dynamic and ever-changing, the Romantic defined reality in terms of evolution and progress. The world came to be viewed as an unfolding lifeforce, not a static equation.

The explosion of culture which followed this shift in sensibilities placed its emphasis squarely on the unique genius that was individual man. Emotionalism was what defined man as human, giving him his creative spark. Consequently, philosophers stopped talking about "Newton's Rational Man" and started dealing with man, "the noble human being." 8 Sentimentalism was in vogue.

8"If it is appropriate to speak of the machine as the symbol of Rationalist thought during the Enlightenment, then the proper symbol of Romanticist thought is the living organism." John A. Garraty and Peter Gay, eds. "New Forces, New Ideas," chap. in The Columbia History of the World (New York: Harper and Row, 1972), 859. For an excellent discussion of the ideology of the preceding century, see 
But in this constantly changing and evolving world diversity threatened to overwhelm the Romantics in an avalanche of detail. How to make sense of it all? The answer was to adapt the arguments advanced by evolutionary biologists. Social theorists applied the concepts of evolutionary, biological change directly to the entire history of human civilization. If individual man was constantly growing and changing, why not entire societies? Cultural and economic progress soon came to be viewed as the natural evolution of mankind.

With this new emphasis on the "biological" basis of society, one strain of Romanticism envisioned man as a creature innately conditioned by his membership in a particular race and nationality. Entire countries soon had supposedly predictable characteristics based upon "biological" laws. The implications of this latent racism were to support a new brand of American nationalism. Finally, by mid-century the challenge of the growing middle classes could no longer be ignored. The leveling process that conservatives feared had begun to take place. When westward expansion and economic industrialization led to the election of Andrew Jackson, frontiersman and businessman

George Rudé, "Enlightenment," chap. in Europe in the Eighteenth Century: Aristocracy and the Bourgeois Challenge (Cambridge: Harvard University Press, 1972). 
alike would at least hold the illusion that they lived in an egalitarian, democratic society. 9

Emma Willard's educational thought contributed to this growing sense of American nationalism in three major ways: in the content she chose to include in the school textbooks she authored, in the training she provided for thousands of female teachers, and in her support for the Common school movement. 10

\footnotetext{
Patriotism and the Textbooks of Emma Willard

There are those, who rashly speak, as if in despair of the fortunes of our republic; because, say they, political virtue has declined. If so, then is there the more need to infuse patriotism into the breasts of the coming generation,
}

\footnotetext{
${ }^{9}$ An excellent treatment of the role of "Democratic Rhetoric" in the formation of Jacksonian Age is contained in Frederick J. Anteczak, Thought and Character; The Rhetoric of Democratic Education (Ames: Iowa State University Press, 1985). Of particular interest for this paper are Chapter 4, "Education of the Democratic Audience: The Circuit of Public Speech," and Chapter 8, "Education in Thought and Character: The Rhetorical Reconstitution of Democracy."

10 The concept of the "Republican Mother" is developed by Linda K. Kerber, "The Republican Mother: Women and the Enlightenment-An American Perspective, " American Quarterly 28 (Summer 1976): 187-205. Kerber later expanded this idea in her book Women of the Republic: Intellect and Ideology in Revolutionary America. Kerber says of Emma Willard, "She believed that young women needed to know the history of their own country more than they needed to know about Greece and Rome, . . " Kerber, women of the Republic, 215 .
} 
Emma Willard wrote in the Preface of the 1843 edition of her Abridged History of the United States: or, Republic of America.

And what but the History of our peculiar, and complicated fabric of government. . . can impart such a knowledge of the powers it gives, and the duties it enjoins, as shall enable our future citizens, to become its enlightened and judicious supporters? 11

Like most of her generation, willard had unwavering belief in the power of education to shape the moral character of American politics. The medium she used to spread this message was her textbooks.12 In her faith in the written word she was not alone. Textbook writers of the period often had an inflated idea of the effect their printed words would have on the development of school children. In her landmark study of nineteenth century schoolbooks, Ruth Miller Elson found that living life as a virtuous American citizen was the main point of almost all of these texts. Miller states,

\footnotetext{
IlEmma Willard, Abridged History of the United States; or Republic of America (New York: A. S. Barnes and Co., 1844), vi.

12 "Women were not commonly textbook authors until well into the 19th century. Among the prominent authors may be mentioned Mary Swift, Mrs. Marcet, Mrs. Willard and Mrs. Phelps. Mrs. Willard wrote texts in the fields of history and geography, while the other three wrote mostly elementary science books. Near the end of the 19th century a number of other women began to write texts, particularly in the fields of reading and English." John A. Nietz, The Evolution of American Secondary School Textbooks (Rutland, Vermont: Charles E. Tuttle Company, 1966), 9.
} 
The purpose of nineteenth-century American public schools was to train citizens in character and proper principles. - . They were much more concerned with the child's moral development than the development of his mind. The important problem for nineteenth-century American educators was to mold the wax [of the child's mind] in virtue rather than in learning. 13

When she began her own school for women in Troy, New York, Willard could find no suitable textbooks for her young female scholars, so she wrote her own. While she also wrote textbooks on such diverse topics as Astronomy and Physiology, it was her history and geography texts which were the most popular.14 Not only were these texts popular, they were fundamental in conveying Willard's views on America, citizenship and patriotic responsibility. In speaking of Willard's History of the United States or Republic of America, her biographer and admirer John Lord, stated that "This history gives evidence of the workings of her own mind

\section{$13_{\text {Ruth Miller Elson, Guardians of Tradition, }}$} American Schoolbooks in the Nineteenth Century (Lincoln: University of Nebraska Press, 1964), 1. See also Nietz, The Evolution of American Secondary School Textbooks, 242-43.

${ }^{14}$ The works in question are: Emma Willard, Astronegraphy, or Astronomical Geography, with the Use of the Globes (Troy: Merriam, Moore and Co., 1854); Emma Willard, Respiration and Its Effects: Most Especially in Relation to Asiatic Cholera and Other Sinking Diseases (New York: Hunnington and Savage, 1849); Emma Willard, Treatise on the Motive Powers which Produce the circulation of the Blood (New York: Wiley and Putnam, 1844). 
[emphasis mine]. . . It is more fresh, vivid, interesting and compact, than any other of her histories."15

The study of history, Willard's first love, was first and foremost a vehicle for instilling loyalty to a particular nation, a particular people, a particular form of government and a particular way of living. In the history of the founding of the United States she found virtue, truth, thrift, hard-work, Christian values and all other qualities which were "right." For Emma Willard, there was only one best model and that was America. The rest of the world could learn from its virtuous example. "As it respects the most important advantage of the study of history, which is improvement in individual and national virtue, we come boldly forward to advocate a preference for the history of the American Republic."16

One way in which Willard's textbooks helped to build a united national character was through the utilization of a particular type of terminology. Willard's history books constantly referred to common national ideals. For example, concepts such as "liberty," "freedom," and "individual

\footnotetext{
$15 \mathrm{John}$ Lord, The I,ife of Emma Willard (New York: D. Appleton \& Co., 1873), 315.

16 Emma Willard, History of the United States or Republic of America, Exhibited in Connexion with Its Chronology and Progressive Geography, by a Series of Maps (New York: White, Gallaher and White, 1830), Introduction, xvi.
} 
rights," are sprinkled throughout her works and are practically synonymous with what she meant by "the American form of government." "The government of the United States is acknowledged by the wise and good of other nations to be the most free, impartial and righteous government of the world."17 "The good and wise of every land look to your country [she admonished her readers] to move, before the nations, as did the pillar of fire before the Israelites, to lead the way to Iiberty and happiness." Lest her students forget their part in all of this, she reminds them that "It rests with you to realize, or disappoint their hopes."18

"American" terms are also contrasted with "un-American" terms. Not only is the American form of government the best mankind had yet seen, it was the antithesis of the corrupt, decaying governments of Europe, which were class-ridden, riddled with vice and reactionary. 19 That the leaders of the 17 Ibid., 15 .

18 Emma Willard, Geography for Beginners, or the Instructor's Assistant in Giving First Lessons from Maps, in the Style of Familiar Conversation (Hartford: Oliver D. Cooke and Co., 1826), 206.

19 Willard did acknowledge the common ties between England and America and while not approving of the French per se, her friendship with the Marquis de Lafayette did soften her perspective on that country. For a description of the visit of Lafayette to Willard's Troy Female Seminary, see Alma Lutz, "Lafayette's Visit," chap. in Emma Willard, Daughter of Democracy (Boston: Houghton Mifflin, 1929). For a description of Willard's return visit to France see Emma Willard, Journal and Letters from France and Great Britain (Troy: N. Tuttle, 1833). 
"Old Order" should be jealous of America's prosperity, that they should daily predict the downfall of the infant republic, and that thousands should flee to the freedom of America's shores, Willard taught her students to believe was a natural consequence of America's development. "Having shown its cause, we assume the fact, denied by none, of the hostility of European absolutists to American free institutions. . . [they] have been in constant expectation, that the American government would, through its feebleness, fall into anarchy and subsequent despotism."20 Willard's history texts also used heroes to instill moral principles by example. The lives and achievements of men such as Washington, Franklin, and Jefferson were faithfully chronicled. It was not the actual personalities or accomplishments of the heroes, however, which were of educational importance so much as the "American" value that each man illustrated (i.e., adherence to democratic principles, love of freedom, willingness to fight for liberty). The story of Roger Sherman included in Willard's Morals for the Young is a typical example.

20Emma Willard, Last Leaves of American History: Comprising a Separate History of California, (New York: A. S. Barnes and Co., 1853), 267. Willard's fervent patriotism has been labeled "jingoism" by some authors, but taken in the context of the times, it is nothing more than the norm. See Daniel H. Calhoun, "Eyes for the Jacksonian World: William C. Woodbridge and Emma Willard," Journal of the Early Republic 4 (Fall 1984): 1-26. 
When ROGER SHERMAN, one of the signers of the Declaration of Independence, was apprenticed to a shoemaker, there were many young men, with rich fathers, who thought themselves above him, because they were not obliged to labor;-who afterwards-when, by virtuous industry of mind and body, he became a man of great eminence, a distinguished member of Congress, and a Judge-could bow to him very low. Their names are now forgotten, while his will be handed down to the latest posterity.21

Like many of the textbook authors of her day, Emma Willard's books expanded the moral virtues exhibited by American heroes and applied them to the nation as a whole. For example, the fact that "the colonists received no assistance from England," in their struggle to carve out a living in the American wilderness, resulted in a people whose "toil and danger made them strong and brave," qualities Willard saw as particularly American.22

While this belief that all things American were perfect may seem strangely racist or jingoistic to the modern reader of Willard's works, it was a commonly held viewpoint in the early nineteenth century. This can be attributed to several prejudices: the popular belief in the biological basis of national culture; a definition of national character

$21_{\text {Emma Willard, Morals for the Young; or, Good }}$ Principles Instilling Wisdom (New York: A.S. Barnes, 1857), 57 .

22 Emma Hart Willard, Abridged History of the United States; or Republic of America (New York: A.S. Barnes and Co., 1852), 108. Emma Willard, Abridged History of the United States: or Republic of America (New York: A. S. Barnes and Co., 1868), 179-80. 
determined by geography; and a faith in America as God's chosen people.

First, the concept of nationality during this period was believed to stem from biology as well as culture. Like many of her time willard felt that, "The character of a nation is marked in some measure, with the peculiarities of the race to which they belong [emphasis mine]."23 This pseudo-scientific philosophy rapidly became integrated into the mainstream of the American conscience.

The results of this "biological" rationale in turn had a significant impact on American social theory. Herbert Spencer's bastardization of Charles Darwin's theory of competitive biology in the later half of the nineteenth century would lead many to view entire countries as having distinctive "personalities." This mish-mash of philosophy and physiology went far toward providing an "organicallybased" justification of national character. The beginnings of this position can be traced, at least in part, to the words of patriotic writers such as Emma willard. The meaning of national sovereignty, by then, was often defined was a "distinct people."24

23William C. Woodbridge and Emma Willard, Universal Geography, 4th ed., (Hartford: Oliver D. Cooke and Co., 1831).

${ }^{24}$ The Romantic movement's emphasis on the organic nature of the state was to split off into various new schools of philosophy from Hegel to Herbert spencer. A common theme 
Second, it was held that the character of a nation's people was defined to a large extent by the geography of their country; thus educators felt that the study of geography and history were inseparable. In Emma Willard's textbooks, this combination was viewed as indispensable to the development of future American citizens. In the Preface to the fourth edition of her Universal History she admonished the student to "learn to connect the mental sublime of the story of our fathers with the natural grandeur of our scenery," and she argued that "our youth should be directed first to the study of our own history, keeping in view its connexion [sic] with our geography."25

As Murray R. Nelson has noted, "Willard saw history and geography teaching, then, as going hand in hand. . . . [She] combined ethnographic [her term, emphasis mine] and chronological forms of teaching history, i.e. from country to

with many of these schools, however, was the belief that individual countries, like the people who inhabit them, each possessed a uniquely different "national character." Whether or not this "national character" was the result of culture or biology was debated. That it existed in each sovereign nation, was not. For an excellent discussion of each point of view in America, see "The Absolute Immigrates to America: The St. Louis Hegelians," and "The Evolutionary Controversy," chaps. in Elizabeth Flower and Murray G. Murphey, A History of Philosophy in America (New York: G. P. Putnam and Sons, 1977).

$$
25 \text { Willard, Universal History, } 4 \text { th ed., } x v \text {. }
$$


country or through the centuries."26 Ruth Miller Elson accurately sums up this position. "Influenced by Romantic nationalism, [textbook writers such as willard] often devote more space to the definition of national character. . . than to the description of natural features and economic development. " 27

A third influence was also at work among these cultural patriots. In Willard's textbooks, liberal values combined with a divine blessing from God to present our nation with a set of certain "natural rights and obligations" unique to America. Among these "natural rights and obligations" were one's duty to country, responsible participation in its government, obedience to a just civil law, the right of free worship, and most significantly, the "natural right to property."

For Emma Willard, like most of her class, the right to property was fundamental to the proper ordering of the universe. It was also a convenient way of defending the status quo and retaining the middle-of-the-road approach to progress with which she was comfortable.

But when men divided out the earth, and one took one portion of the land which God had made for all, and

$26_{\mathrm{Ne}}$ son, "Emma Willard: Pioneer of Social Studies Education," 250 .

27 Elson, Guardians of Tradition, American Schoolbooks of the Nineteenth century, 102 . 
another took another portion, and the law of the realm sanctioned this division-then certain persons acquired the right to property in land; and an obligation came on others, to abstain from that previously possessed. These take their rise from the general obligation resting on all, to obey the Civil law, or the Law of the Land.28

In her textbooks, liberal values, Romantic nationalism, geography, and evolutionary biology all combined to portray the high moral character of America. For Emma Willard and most of her countrymen, education was seen as the central means of fostering a virtuous citizenry and a democratic union. Her widely read schoolbooks consistently impressed these messages upon teacher and student alike. 29

You are hereafter to constitute a nation, and that nation the first great American Republic. Proud and happy above all of the nations who have gone before you, will your political destiny be, if you prepare yourselves by education to sustain the government under which you have the happiness to be born. 30

28 Willard, Morals for the Young; or, Good Principles Instilling Wisdom, 129. For a different perspective on Willard's view of nationalism, history and geography see, Calhoun, "Eyes For the Jacksonian World." Calhoun states that later on Willard's jingoism got the better of her, "Others, such as even the aging Willard, lapsed into the racial defensiveness that comes to the frightened old," 22.

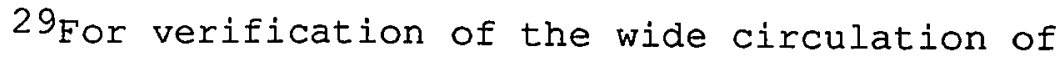
Willard's textbooks see, "The Writings of Emma Willard," chap. in Lord, The Life of Emma Willard. Nietz, The Evolution of American Secondary School Textbooks, 265. "According to S. A. Allibone's (1876) Critical Dictionary of English Iiterature and British and American Authors, the sales of her books and charts numbered more than a million at the time of Willard's death." Nelson, "Emma Willard: Pioneer in Social Studies Education," 251.

30 Willard, Geography for Beginners, or the Instructor's Assistant, 109. 
Progressive educators such as Willard, acknowledged that the dissemination of these patriotic beliefs should start in the classroom. Consequently, it was the female teacher who was given a large portion of the responsibility for spreading the patriotic message that these textbooks contained.

\section{Republican Motherhood and the Female Schoolteacher}

The Troy Female Seminary, officially opened in 1821 but tracing its roots to 1814 , was the first permanent institution offering American women a curriculum similar to that of contemporary men's colleges. [Emma Willard] The founder stated her purposes clearly: to educate women for responsible motherhood and to train some of them to be teachers. 31

At the turn of the century, a useful role was finally found for the educated woman in the classrooms of America. No longer did women have to wonder why they should bother to get an education; here was a practical solution with solid cultural benefits.

The training these women received, also solved several economic, social and philosophical problems that had begun to surface. The combination of women's "natural" role as the moral teacher of the child and the nation's need for raising virtuous citizens provided a logical reason for educating women. This compromise resulted in what Linda Kerber has termed the "Republican Mother."32

$$
\begin{aligned}
& 31_{\text {Scott, "The Ever Widening Circle," } 3 .} \\
& 32 \text { Kerber, "The Republican Mother, 187." }
\end{aligned}
$$


The role of the "Republican Mother" developed as the result of several influences. First and foremost was the creation of a growing economy based upon written communication. Until the country needed a literate female population, women's schooling had received very little support. Educational opportunities for women in the preRevolutionary war period had been much more limited than their male counterparts and consequently their literacy rate was substantially less than men.

After the Revolutionary War, however, with the creation of a new nation, a premium was placed upon literacy for both sexes. Thus, the call for a national system of education began in earnest. While the narrowing of this gender-based literary gap cannot be precisely dated, most educational historians do acknowledge that the second half of the eighteenth century was the period during which huge strides were made in improving female literacy. 33 In other words, in order to do business, citizens needed to be able to do more than simply sign their names.

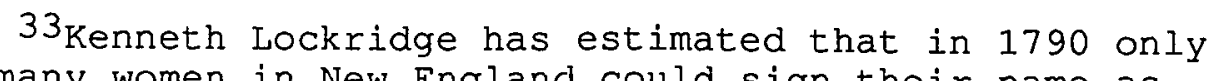
half as many women in New England could sign their name as could men. Kenneth Lockridge, Literacy in Colonial New England: An Enquiry into the Social context of Literacy in the Early Modern West (New York: Norton, 1974), 38-40. Also see Thomas Woody, A History of Women's Education in the United States (New York: The Science Press, 1929), chaps. 26 . 
Many people feared, however, that with this increase in female literacy, many disturbingly "liberating" tendencies would surface. Could the educated woman still be feminine? Would she forget her place? How would her education affect others who depended upon her? All these questions were unsettling to many.

Consequently, the question of exactly how much education women should receive and what they should do with it once they did receive it, became very thorny problems indeed. As Kerber has noted, "No social change in the early Republic affected women more emphatically than the improvement in schooling, which opened the way into the modern world."34

The second influence which affected the creation of the "Republican Mother," has already been noted. This was the question of woman's rationality and her consequent place in the civil state. The tradition of the English and French Enlightenment ennobled mankind by endowing him with a rational nature. It also prescribed that he use that rationality to participate in the body politic. But, by and large, this same philosophical tradition rarely embraced women. With the possible exception of Condorcet, European Enlightenment thinkers had had little belief in the "rationality" of women. The result of this ambivalence was

${ }^{34}$ Kerber, "Education and Intellect," Women of the Republic, 193. 
that women were defined as quite literally outside the political state, even a supposedly democratic or liberal one. There also was the opposite side of the "rationality argument." If women were not "rational" in the Enlightenment sense, then they must be "emotional" by nature. This supposedly emotional predisposition on the part of women uniquely fitted them, so it was argued, for the role of wife and mother. The glorification of the natural mother has already been discussed in some detail earlier in this paper. Here it need only be pointed out, once again, that the role of women was considered filled in marriage and reproduction. If women had any rationality at all, it was to be used within the strict confines of their home and in the education of their children, since "the antifeminist system of belief dominated the perception of women in the nineteenth century. It provided women with supreme domestic powers through religious influence and the education of children, though it extracted a price of powerlessness beyond these spheres."35 A natural consequence of this philosophic thought was a division of labor based upon biology.

Finally, there was usefulness. American education, unlike its European counterpart, had always been conceived of

35 Philida Bunkle, "Sentimental Womanhood and Domestic Education, 1830-1860," History of Education Quarterly 14 (Spring 1974): 13. 
as serving a useful purpose. For most Americans, usefulness meant economics. While a select few of the idle, decadent, European upper class enjoyed "scholarship" which produced no monetary results, educators in America declared that as a democratic republic, the United States would educate all its citizens equally.

Barred from most professional occupations, women in America translated that educational "equality" into social usefulness. "What must have seemed a vulgar utilitarianism to those who were addicted to aristocracy was considered by [Benjamin] Rush as the only basis for female education suited to the United States."36 In considering women as a segment of the work force, their "usefulness" as well as their "natural" function as wives, mothers and instillers of morality, had to be figured into the educational equation. The answer to the various problems propounded was the concept of the "Republican Mother" and it was to have significant consequences for female education. Linda $K$. Kerber has outlined the philosophical solution concisely. Western political theory, even during the Enlightenment, had only occasionally contemplated the role of women in the civic culture. It had habitually considered women only in domestic relationships, only as wives and mothers. It had not devised any mode by which women might have a political impact on government or fulfill their obligations to it. The Republican Mother was a

36 Hansen, Liberalism and American Education in the Eighteenth Century, 58 . 
device which attempted to integrate domesticity and politics. 37

The creation of the "Republican Mother" was the result of an economic, political and philosophical division of labor between the sexes. Males were thought of as having economic and political responsibilities, as citizens and economic providers for the family. The responsibilities of women were determined to be important for different, but supposedly equally important, reasons. They were to have responsibility for the administration of household domestic operations. Even more importantly, they played a primary role in the education of their children and served as moral guardians to the young. Outside this "sphere" most early nineteenth century women did not tread.

In this way, America's "Republican Motherhood" provided the answer to the question of exactly why women needed to be educated. 38 If women could not be prepared for traditionally male professions-medicine, ministry, or the law--then they could easily be "educated" to be better wives and wiser mothers.

37 Kerber, "The Republican Mother," 203.

38 "Those who were skeptical of education for women, [Benjamin] Rush declared, were the same who opposed 'the general diffusion of knowledge among the citizens of our republics.' Rush argued that 'female education should be accommodated to the state of society, manners and government of the country in which it was conducted'." Quoted in Kerber, women of the Republic, 211. 
But as the country continued to grow and expand, the need for qualified classroom teachers ballooned. Where could America find these teachers? The answer lay in a logical extension of the "Republican Mother" into the role of schoolmistress.

This new role for women as guardians of moral standards was unique to American culture. It immediately paved the way for the emergence in the 1830 s of the woman teacher who could safely be charged with the education of the young of both sexes. 39

The nineteenth century female school teacher was simply the same moral, virtuous "Republican Mother" writ large.

\section{Emma Willard's Teachers}

Truth is the proper object of teaching. Truth received into the mind is knowledge.

To teach error is worse than not to teach at all. Error in the mind, is never knowledge.

Emma Willard, March, 1855.40

The cause of American education is emphatically the cause of humanity at large; . . May those who labor in it receive the blessing of the Almighty God.

Emma Willard, Sept. 1855.41

$39 \mathrm{Jill} \mathrm{K}$. Conway, "Perspectives on the History of Women's Education in the United States," History of Education Quarterly 14 (Spring 1974): 4.

40 Emma Willard, "The Schoolmistress, Article 2," New York Teacher 3 (March 1855): 318.

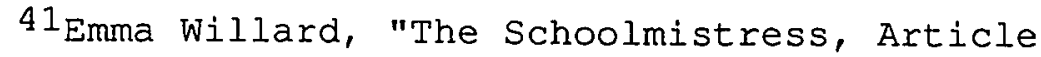
Seventh," New York Teacher 3 (September 1855): 368. 
As Anne scott has pointed out, the argument that the continuation of the republic depended upon educated women was not unique to Emma Willard. Evidence of this position can be found in the writings of educators directly after the ratification of the Constitution. 42 The idea the public should spend money on the education of women and that these same women could be trained specifically for the profession of teaching, however, was uniquely Willard's.

The training willard provided for her female students was significant in two ways. First, Willard's young, educated female teachers proved that the same "mothering" skills needed for raising a family could be transformed into a nurturing presence in the classroom. Female education did not necessarily make a woman any less "motherly," Willard argued. In fact, she felt that classroom teaching was only an amplification of a natural feminine role.

Secondly, properly trained female teachers provided a cheaper, more uniformly professional solution to the problem of how to disseminate the democratic values which were essential to the definition of nationhood the growing republic demanded. Willard felt that the logical extension of the female "sphere" was either as ruler of the classroom or of the household. In both arenas, educated women were the 
guardians of the morality of the republic and the natural teachers of children.

Emma Willard was convinced that the only way to achieve universal education was through multiplying the numbers of teachers. She was also convinced that women, by their nature, made better teachers than men. Women, designed by nature to care for children, were given "in greater degree than men, the gentle arts of insinuations,. . . a greater quickness of inventions, . . . and more patience."43

In advocating the training and employment of female teachers, willard did not envision herself as a crusader for women's rights. She simply saw her argument as the logical culmination of the patriotic role of the mother. She wrote,

It is the duty of a government to do all in its power to promote the present and future prosperity of the nation over which it is placed. This prosperity will depend upon the character of its citizens. The character of these will be formed by mothers; and it is through the mothers that government can control the characters of its future citizens, to form them such as will insure their country's prosperity. 44

Those qualities which made women good mothers, also made them good teachers. Among those qualities willard listed "intellectual ability," "physical ability" and most importantly "moral ability." The "thousands of the rising

43 Emma Willard, An Address to the Publici Particularly to the Members of the Legislature of New York, Proposing a Plan for Improving Female Education (Middlebury: J. W. Copeland, 1819), 23.

$$
{ }^{44} \text { Willard, Plan, 11-12. }
$$


generation who are under your instruction [she wrote to her young teachers in 1838], may receive a new impulse in human knowledge and impious principles" and in doing so "you may all bless the families and the country to which you belong and be in the way to everlasting life." 45

Willard also provided economic justification for the training of the female teacher. The new republic would benefit not only from having these "natural teachers" as moral guardians in the household, but also by having them as paid professionals in the classroom. 46 With the mobilization of women as an economic resource, male classroom teachers were freed to get on with their real interests: commerce, politics and trade. Willard stated that by "properly plac[ing] the business of teaching children in hands now

\footnotetext{
$45_{\text {Emma Willard, Letter Addressed as a Circular to }}$ the Members of the Willard Association, for the Mutual Improvement of Female Teachers (Troy: Elias Gates, 1838), 5.

46 Willard was in the practice of actually loaning money to deserving students who wished to become teachers, in order that they might pay their tuition and living expenses while at her Troy Female Seminary. Henry Barnard wrote that, "Mrs. Willard's practice of educating teachers, when it became enlarged and systematized, embraced, in theory, a self-supporting theme." In actuality many of these loans were often cancelled or collected without interest. Thus Emma Willard personally financed (in a small way) the training of America's teachers. Henry Fowler, "The Educational Services of Mrs. Emma Willard," in Henry Barnard ed., Memoirs of Teachers, Educators and Promoters and Benefactors of Education, Literature and Science (New York: F. C. Brownell, 1861; reprint, New York: Arno Press and the New York Times, 1969), 153 (page reference to reprint edition).
} 
nearly useless to society [women], and tak[ing] it away from those [men] whose services the state wants in other ways" the entire country would be better served. 47 Women could sit around looking useless and decorative (as their European sisters were wont to do) or, as Willard argued, they could be pressed into the service of their country by teaching America's youth the proper duties of citizenship. It made good economic sense.

Several historians have argued that in pursuit of the goal of national education, female teachers were generally taken advantage of in that they were often paid less and worked harder than their male counterparts. 48 But as many researchers have also pointed out, the "democratization" of American education finally allowed the "school master" to become the "school teacher" and it did open the way for one of the first professional employment areas for women. Unfortunately, the employment of women as teachers resulted in a corresponding decline in the status of the profession itself, according to $H$. Warren Button and Eugene F. Provenzo. "If less formal schooling was needed by

47Willard, Plan, 22.

48 For a discussion of the economic position of female teachers, see Bunkle, "Sentimental Womanhood and Domestic Education, 1830-1870; Conway, "Perspectives on the History of Women's Education in the United States"; Fred M. Binder, The Age of the Common School, 1830-1865 (New York: John Wiley and Sons, 1974), 76. 
teachers, it became seen [sic] as more appropriate, as well as cheaper, to employ women as teachers." Button and Provenzo make the point that often the poor economic status of the pupils "tended to reduce the status of teachers, who were themselves most often from families of limited means." 49 Although her educational philosophy and firm patriotism never allowed Emma Willard to stop believing that the female teacher was the answer to America's need for national education, she constantly demanded that these women be paid what they were worth. "It was never my intention to place you in such bondage, and its not now my wish that you continue in it" she told her young teachers. "You are wronged, my daughters, and you must summon the resolution to resist." She then admonished them to "Go to your employers, and respectfully represent to them your case."50

By demanding that her young, educated schoolmistresses be properly trained, properly treated and properly paid, Emma Willard did much to professionalize the field of teaching. In this way she extended the social and political role of women in the early nineteenth century and contributed

\footnotetext{
49A. Warren Button and Eugene F. Provenzo, Jr., $\underline{A}$ History of Education and Culture in America (New Jersey: Prentice Hall, 1989), 96. 50 Willard, "Letter Addressed as a Circular," 6.
} 
significantly to the spread of education and democratic principles in the new nation.

She did all of this without stepping outside what most people saw as the "proper" role for women. Her educational philosophy included a critical link between the concept of a rational, educated woman as natural teacher of the child, and her belief that it was her patriotic duty to assist in the development of a uniquely American culture with a free, virtuous and democratic citizenry. The vehicle for reform was the schoolroom.

As her life progressed, a significant part of Emma Willard's educational philosophy revolved around the establishment of a national system of education--open to all, based upon liberal, democratic principles and taught by America's women. She found her answer in the common school Movement .

Liberal Principles, American Education and the Common Schools

Between 1830 and 1860 the United States added over a million square miles of territory and all but tripled its population.51 With this vast explosion in size and population, the need for a national system of education in

$51_{1,234,566}$ square miles of territory were added to the United States between 1830 and 1860; the population went from 12,866,020 to 31,443,321. Binder, The Age of the Common Scheol, 4. 
the United States became critical. America's commerce demanded a skilled and educated populace.

The need was patriotic as well as economic. As noted earlier, the process of building a national culture demanded a certain homogenization of America's disparate viewpoints. As the industrial revolution transformed the countryside into cities, it seemed to many people that the very future of the United States depended upon the moral education of its citizens. Dissemination of certain moral values supposedly guaranteed national stability and safeguarded a system of gradual, not revolutionary, progress.

Faith in the ability of education to instill proper American values through the school system was never stronger than in this early national period. This faith, justified or not, had been an integral part of the American democratic experience. The ideal of free public elementary education for all citizens was always the hope of intellectuals such as Jefferson, Rush, and Webster. This belief carried through (albeit somewhat diminished) until the present day. In his study of the United States Office of Education, Donald Warren writes,

Education, as formulated during the country's beginning years, represented a national, as over against a sectional concern, and a chance for achieving nationhood. Talk about education braved unsettling realities; it endured, not because schools fulfilled the high expectations, but inexplicably because they did not. American education, as both process and institution has 
never escaped the reformist role in which it was cast in the republic's first days. 52

Prior to the first few decades of the nineteenth century, the ideal of a national system of education was simply that, an ideal. Although programs for support of free public education dated back to the early colonial period, ineffective laws, the unpopularity of property taxes, scarce resources (primarily teachers), a small population, and the physical isolation of many towns, all combined with the continued dominance of an agrarian economy to minimize the call for the establishment of a national system of education. This left the support of those schools which did exist either to charity, private benevolence, or the churches.

As the nineteenth century progressed, however, several forces combined to call for a reform in this piecemeal approach to education. Among the most significant of these political forces was the growing wave of foreign immigrants who came to America during the 1820 s and 1830s. The arrival of these new citizens "yearning to breathe free" caused a major shift in the thought of American educators.

To accommodate these people, schools came to be seen not only as a means for creating responsible individuals and citizens, the call of Rush, Knox, Sullivan and others, but also as a way to bring about the assimilation of these

52 Button and Provenzo, History of Education and culture in America, 103. 
"foreigners." There was a belief that this foreign influence had to somehow be neutralized, and its "revolutionary" effects defused. As Calvin Stowe, a major figure in the Common School Movement, explained in 1836,

It is altogether essential to our national strength and peace, if not even to our national existence, that the foreigners who settle on our soil, should cease to be Europeans and become American; and as our national language is English, and as our literature, our manner, and our institutions are of English origin, and the whole foundations of our society English, it is necessary that they become Anglo-American. 53

Secondly, with this influx of immigrants came the growth of the cities and a corresponding shift from a mercantile and agricultural economy to an industrialized one. With the growth of the cities also came the eventual extension of political suffrage.

The effect of many of these significant forces on American educational philosophy has been discussed earlier in this paper. What is important to note here, however, is that the growth of the industrialized, urban environment with its organized, laboring classes created a demand for better education at the lower levels of society. In his classic on the history of American public education, Ellwood P. Cubberley noted that these new citizens began to use the basic tenets of liberal philosophy against the very system

${ }^{53}$ Quoted in Button and Provenzo, History of Education and Culture in America, 103. 
which kept them down. Cubberley pointed out that, "The representatives of the newly organized labor movement joined the demands for schools and education, urging free education of their children as a natural right [emphasis mine]."54 Not unlike the arguments of certain feminists, education was envisioned as the key to individual emancipation, personal empowerment, and upward economic or social mobility. Finally, a growing group of educational reformers such as Horace Mann and Henry Barnard called for a national system of education for humanitarian reasons. Primarily white, upper class, New England professionals, these reformers zeroed in on outdated administrative practices, inefficient instructional techniques, and punitive pedagological theories as major impediments to the spread of a more egalitarian education. They saw themselves as social reformers serving the cause of American patriotism.

Following in the Enlightenment liberal tradition, many of these reformers felt that the role of education was the realization of individual human potential. Unfortunately,

\footnotetext{
${ }^{54} \mathrm{El}$ lwood P. Cubberley, Public Education in the United States: A Study and Interpretation of American Educational History (Cambridge: Houghton Mifflin, 1947), 157. For a very interesting discussion of the philosophical foundations of education and labor in the United States see Joel Spring, "Political Theories of Education: The Economic State," chap. in Educating the Worker-Citizen, The Social, Economic, and Political Foundations of Education (New York: Longman, 1980).
} 
the essentially conservative background of many of these men also led them to limit their definition of individual self realization only to those of certain talents or ambitions. In this way they were not unlike earlier liberal

intellectuals such as Thomas Jefferson.55 An inherent conflict existed between the need to provide opportunities for individual development, and society's need to maintain political order and stability. Such a philosophical dichotomy is still relevant. Joel spring explains, "the dilemma facing educational systems as they try to produce loyal citizens who are not so blinded by loyalty and obedience to the law that they become servants of power," is one which has been central to representative governments

\footnotetext{
55 In his books, The Americans: The Demecratic Experience and The Americans: The National Experience author Daniel J. Boorstin deals with the social function of education and language in the formation of an American educational elite. Boorstin's thesis is that dissemination of a national American culture through art, language and higher education was fundamental in the country's move from sectionalism to nationhood. He also points out that it helped perpetuate certain social and economic hierarchies in the northeastern and the southern parts of the United States even in the face of "democratization." Knowledge and learning were powerful forces in and of themselves. See in particular, Daniel J. Boorstin, "Language, Knowledge and the Arts," chap. in The Americans: The Democratic Experience (New York: Vintage Books, 1974).
} 
throughout time. 56 It is a contradiction which still haunts the American school system. 57

Emma Willard and the common school Movement

For Emma Willard and other nineteenth century New England educational reformers, nationalism was one of the major forces which drove their efforts on behalf of the Common Schools. Their brand of Americanism reflected a predominantly white, New-England, upper class, Protestant heritage, and their reforming efforts were essentially moralistic in nature. They saw their battle as one against the possible moral decay and downright sinful behavior of America's future citizens.

Henry Barnard, editor of the connecticut Common School Journal and the American Journal of Education, as well as Secretary of the State Board of Commissioners for the Common Schools in Connecticut, was one of those who had become increasingly concerned about the decay of America's school

\footnotetext{
56 Spring, Educating the Worker-Citizen, 3.

57 John Dewey, arguably the twentieth century's greatest educator, bent his entire effort to see the question of educational philosophy in terms of public interest merging with private ones: practice versus philosophy. He wrote, "If we are willing to concede education as the process of forming fundamental dispositions, intellectual and emotional, toward nature and fellow man, philosophy may even be defined as the general theory of education.. . philosophy is [then] the theory of education as deliberately conducted practice." John Dewey, Demecracy and Education, (New York: The Macmilian Company, 1916).
} 
system. In 1840, as an indirect result of an address which Barnard had asked her to write for presentation to interested citizens, Emma Willard found herself elected to the position of Superintendent of the Common Schools for Kensington, Connecticut.

This call to action came at a critical point in Willard's personal life. After a disastrous second marriage and subsequent divorce, willard had retreated to the seclusion of her sister's home, convinced her work in education was at an end for awhile. But even while involved in her own personal problems, Willard continued to be concerned about the moral fate of America's educational system. She wrote,

About three years before leaving the Troy Seminary, my mind was aroused to alarm concerning the condition of the common schools of my native State, by the representations of Miss Robbins, a zealous friend of education, who had just been making a tour of observation through these schools. Looking into the matter, I found that it was not in Connecticut only, but in New York and throughout the country; that there was a general decadence of the Common School [emphasis mine] .58

Willard's contribution to the Common School Movement reflected much of her own personal educational philosophy. The work she accomplished focused on practical solutions, used moderate not radical methods, and included an essential

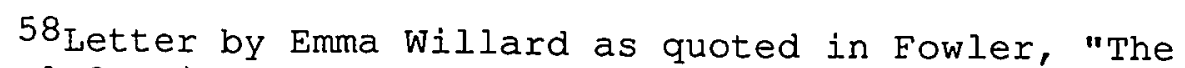
Educational Services of Mrs. Emma Willard," 160. 
role for women, both as teachers and mothers. All of her actions were also based upon her own personal beliefs about the function of education in her country. Since proper schooling was essential to the continued welfare of the nation, it was positively her patriotic duty. "Our Common School system [she wrote] must be regenerated or our country is undone $" 59$

And she saw much to be accomplished. "Read the Common School journals of Connecticut and Massachusetts," Willard admonished. "Go through the villages of New England, and New York, and mark the dilapidated huts by the dusty wayside, where the children of the district are imprisoned, with less regard to their cleanliness and comfort, than is manifested for that of our state convicts." 60

In a whirlwind of writing, practical solutions to the deplorable state of the nation's schools poured from the pen of Emma Willard. No detail was too small to demand her attention. Believing in the connection between the health of the body and the health of the mind she attacked the physical environment in which students learned. She demanded, "their schoolroom be whitewashed and made neat in every corner." "A

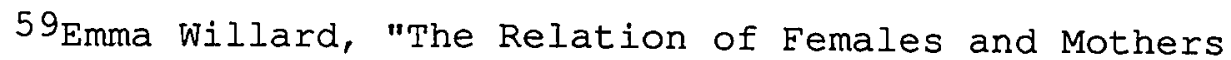
Especially to the Cause of the Common School Improvement," Connecticut Common School Journal 5 (March 1842), 64. 60 Ibid.
} 
vessel to hold rain water," should be provided along with "drinking cups and scouring pails."61 New furniture should be provided for the teacher. The schoolhouse needed a well stocked library, correct seating for its pupils, proper ventilation and "plain curtains on the windows." "Then in regard to the seats, whether they are calculated to insure the comfort, the health and the improvement of the scholars-. ." "And again, how do you find the light of your school house as it affects the eyes of children?"62

In the curriculum and instructional methods used in these schools, Willard also found much to change. In the schools under her care, her "first step was to break up that most disagreeable but universal habit of toning."63 Believing that children needed to understand what they were learning, not just memorizing sounds, she replaced this pointless technique with the more progressive methods of sentence analysis and phonetics.

\section{${ }^{61}$ Ibid.}

62Emma Willard, "The School Mistress, Article Three: The School House," New York Teacher 3 (April 1855): 29-30.

63 Toning was an instructional method which was much employed in the nineteenth century classroom. In the main, it consisted of having the children simply repeat large sections cf printed text simply by "sing-songing" the words over and over again with no attempt made at teaching phonetics. Little to no emphasis was placed upon getting the child to actually understand what he or she was repeating out loud. Letter by Emma Willard quoted in, "Public Examination of Summer Schools," Connecticut Common School Journal 3 (December 1840): 30 . 
The instructional design of most lesson plans used by the teachers cried out for an overhaul in technique. Willard made practical revisions in each of these areas. Believing that education should foster the development of a disciplined and rational mind, she introduced progressive techniques in the study of science and arithmetic, as well as readjusting the school schedules to allow for more time to study these topics.

Finally, religious and patriotic instruction came to occupy a central position in the lessons of her children, as "the amounts of fiction put into the hands of the children, in their daily lessons, [struck her] with surprise and regret."64 Education was to instill proper, practical and useful values in these young people. And who were the logical people to teach these proper values? The women of the town and the female school teacher.

Again Willard looked for practical solutions in line with her philosophical beliefs. Realizing that there was not enough money to hire a full contingent of well-trained teachers, willard began using the older pupils as assistants in the teaching process. This was a technique which she had employed at her Troy Female Seminary for years. Not only did

64 Letter by Emma Willard in "Proposed Plan of Improvement," Connecticut Common School Journal 2 (April 1840): 243. 
it partially solve the teacher shortage, it provided these older students with valuable experience. Willard also initiated a long range solution to the teacher problem.

She introduced a "normal class" for those who were planning to become teachers and for those who assisted in teaching the younger pupils. . . . She held classes for them on alternate Saturdays, instructing them in history, reading, algebra, geometry, and in methods of teaching. 65

A firm believer in the benefit of maternal influence on the education of children, she organized a "Female Common School Association" among the women of Kensington. In an article entitled "The Relation of Females and Mothers Especially to the Cause of Common School Improvement," Willard declared that this Association was the logical extension of the mother's role. "As in a family, no cure on earth can be to little children, like that of the mother, so to the collected children, none can be equal to that of the collected mothers." 66

The responsibilities of the members of this Association, which later became a model for other such organizations, bid them "to learn the condition of every [child] in the district, and if any lack, to provide the needed raiment." Members should also "observe the condition of the schoolhouse and its furniture, the accommodations of the children, and

65 Lutz, Emma Willard, Daughter of Democracy, 214.

66 Willard, "The Relation of Females and Mothers Especially to the Cause of Common School Improvement," 64 . 
their teacher, so that comfort and health may be regarded, and habits, proper and cleanly, may be formed." For the more educated among their members, another duty "is to enter into their [own] course of study, . . to order what classes shall be formed and works shall be studied, and those ones to provide." Those decisions concerned with the actual instructional curriculum, however, needed to be taken along "with the advice of male committees." 67

So it was in the schoolrooms of America that educated women, single ladies, wives and mothers, should find their calling. This was the patriotic role that the nineteenth century woman respectfully could play. This was how she could contribute to the greatness of the republic, and to the ensuring of freedom and liberty. In her writings, willard sounded a call to all American women:

There is a field already whitening to the harvest, and they are the appointed reapers, for it is the peculiar province of woman, to rear the young; and what the individual mother does at home, that should the united mothers do for their children, collected in the village nurseries,--the common school. 68

Emma Willard was sure she was on a divine mission.

67 Ibid., 65.

68 Ibid., 64. 


\section{CHAPTER FOUR \\ EMMA WILLARD'S EDUCATIONAL PHILOSOPHY : REIIGION, REASON AND EDUCATION}

If I have done any good, give the glory to God. I have been impressed with a belief, that He had given me a work to do, and that He sustained me. It was not in human wisdom, certainly not in mine, to see far into the future, and that which does, must be from Him. As for me, dearer is it to my heart, to be His servant--the meanist [sic] of His servants, than to receive the praises of the whole world.

Emma Willard-January $10,1842^{1}$

Since America's birth, the relationship between patriotism, religious belief and scientific rationalism has been an uneasy and explosive one. Whether couched in moral ethics or displayed as sectarian dogma, Americans have at once rejected and embraced the certainty that religion and empirical reason could exist side by side in a democratic country.

At no other time in our country's history was this paradox more strongly felt than in the early national period. Patriotism, morality and science all struggled to find a place in the emerging American culture. Central as this

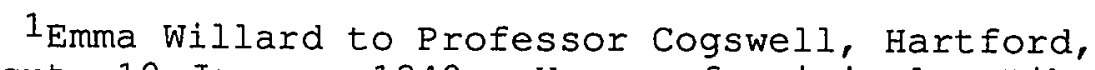
Connecticut, 10 January 1842. Xerox of original. Library Archives, Emma Willard School, Troy, New York. 
struggle was to the early nineteenth century spirit, it was logical that it should influence thoughts on education. Although religious emphases had changed during the nineteenth century, a sense of God permeated the writings on education as surely as a sense of nationalism. The good citizen was the individual dedicated to God, and the good society was one composed of these individuals. "Only as a brotherhood of man under the fatherhood of God would the United States fulfill its God-given purpose in history."2 Educators ultimately saw the future of the new nation as dependent upon loyalty; a loyalty voluntarily given, not legally coerced. The basis of this loyalty was rational enlightenment, religious morality and democratic virtue. The task of American education then, was the creation of a "brotherhood" of Christian, republican-minded citizens. This task sprang from a unique combination of philosophical, religious, economic and scientific circumstances; one which attempted to answer universal questions as old as mankind. It was a uniquely American problem with far reaching solutions, and it owed much to America's intellectual history.

\footnotetext{
${ }^{2}$ Lawrence A. Cremin, American Education, The National Experience, 1783-1876 (New York: Harper and Row, 1980), 49 .
} 
At the center of the country's intellectual tradition lay a world view shaped by the zealousness of its Calvinist founders. Disseminating outward from its New England source, Puritanism enjoyed a metaphysical monopoly in America for almost two centuries. From the landing of the Puritans to the emergence of the Transcendentalists, the major tenets of this religious piety were based in Calvinism. In the late eighteenth and early nineteenth centuries, this was still true. But it was a Calvinism vastly changed. Gone were many of its central beliefs: man's innate depravity, the literalness of heaven and hell, the world of witches and demons. What was left for the American of the industrial age was the underlying moral message of the Calvinists without the divine meaning. The moral atmosphere of the industrial age would have been almost unrecognizable to its originators in the sixteenth century.

By the early nineteenth century, the outward relationship between scholarship and religion had changed as well. Much of the Calvinist moral ethic upon which the school system was based, however, was still in place. This was due to the peculiar history of civic order and education in the New England colonies. The Puritan community had always held scholarship in high esteem. Its leaders saw that scholarship, properly restricted, was necessary to an 
understanding of God's Will and to facilitate that essential Puritan experience, conversion.

But by the 1650s, it had become painfully apparent that a large proportion of the members of the church of "visible saints" were not experiencing the central act of Christian conversion. Even the adoption of the Half-Way Covenant did not solve the problem, and by the 1670s, it was obvious that the "New England Way" was in serious trouble. While there were many social, cultural and economic reasons which accompanied the philosophical breakdown of hard line Calvinism in America, the main factor that would eventually undermine the community of believers was the scientific revolution and the accompanying thoughts of the European Enlightenment. Puritan intellectuals such as Cotton Mather struggled to combine Calvinist Protestantism, based upon a tradition of medieval scholasticism and Renaissance humanism, with the new ideas of Newtonian science and Lockean psychology.

In the long run, such synthesis was less than successful. Even the brilliant efforts of Jonathan Edwards, arguably America's greatest theologian and philosopher before the Civil war, could not bend Puritanism far enough to fit in with the rationalism of the new scientific age. There were ideas in Calvinism which were diametrically opposed to those of the Enlightenment: predestination vs. free-will; rational 
exploration vs. spiritual revelation; and freedom of will vs. freedom of action. 3

By the last quarter of the eighteenth century the Enlightenment outlook had become the dominant viewpoint of America's most important intellectual, political and social leaders. Men such as Benjamin Franklin, Thomas Jefferson, James Madison and Alexander Hamilton all found something in the thoughts of the Enlightenment philosophers which supported their personal epistemology and moral code. In the sphere of American religion, the Enlightenment was also to have its effect. During the last quarter of the century, the pietistic revivalists in the churches welcomed the ideas of individual free-will and personal freedom that the Enlightenment provided, and they swiftly applied them to thoughts on religion. Its democratic implications were not so enthusiastically embraced, however. After the turn of the century, when the battle had been safely won, these same leaders turned on their Enlightenment friends and labelled them atheists.

\footnotetext{
3 For an excellent discussion of the Puritan philosophy see, Woodbridge Riley, "Puritanism," chap. in American Thought, From Puritanism to Pragmatism and Beyond (Gloucester: Peter Smith, 1959). Also see Lawrence A. Cremin, "Piety Rationalized," chap. in American Education, The Colonial Experience, 1607-1783 (New York: Harper and Row, 1970).
} 
But even these "atheists" had some room for God. Deism, that combination of religion and rationality, was singularly suited to the freethinking, democratic intellectuals of eighteenth century America--men like Jefferson and Franklin. 4 The essential conviction of the Enlightenment was that human reason was the only reliable way for man to know truth. By using reason men could solve all of the social, cultural, scientific and religious problems of the world. The God of the Deists then, had to be a rational God.

But for the common man, this rational God did not provide emotional comfort, and establishment ministers saw the democratic tendencies of this new philosophy as threatening their own positions of power in the churches. Now that the ties of church membership were loosening and parishioners were no longer a captive audience, ministers found it harder and harder to bolster their sagging church attendance.

Religious revivalism appeared to fit the needs of the masses. Starting in the 1740 s and continuing on and off for more than fifty years, religious revivalism had a tremendous impact on American society and consequently on American

\section{It has been argued that Franklin turned away from} radical Deism in the later portion of his life and adopted an "intermediate God" of good works. See "The Impact of Science: Benjamin Franklin," chap. in Elizabeth Flower and Murray G. Murphey, A History of Philosophy in America (New York: G. P. Putnam and Sons, 1977), 99-115. 
education. The first and second "Great Awakenings" swept the nation "leaving no social class, no section of the country, no church body untouched." 5

By the $1840 \mathrm{~s}$ and $1850 \mathrm{~s}$, a generalized Protestant piety had become an integral part of the American definition of education. Teachers, grammar schools, universities, and textbooks all labored together to disseminate this piety among America's citizens. The message they carried was a relatively encompassing one, popular in spirit and millennial in direction. Its substance was shared by an extraordinary variety of denominations, sects and communities.

Emma Willard's personal epistemology incorporated elements of these three main intellectual traditions: the Calvinism of New England's Puritans; the rationalism of the Enlightenment thinkers; and the evangelical piety of America's "Great Awakenings." It is clear that her educational philosophy reflected certain basic assumptions about human nature, the sources and ends of knowledge, and the future of society. All of these assumptions rested upon the same uneasy relationship between rationality and emotion typical of her generation.

$5_{\text {Douglas Sloan, ed., The Great Awakening and }}$ American Education: A Documentary History (New York: Teacher's College Press, 1973), 1. 
Puritan Wisdom

In moving from the Puritan age to that of the Enlightenment, a dramatic shift occurred in the dominant climate of intellectual opinion concerning the actual process of learning. This new process was directly tied to a changing perception of man's relationship to God. While an understanding of the works of the scriptures was still considered important in the pursuit of knowledge, rationalism gave a peculiar twist to the relationship between the thoughts of man and the thoughts of God. The "rational God" of the Enlightenment allowed mankind a closer view of the human cognitive process than did the "inscrutable God" of the Puritans. The "revealed God" of the evangelists allowed man a brief glimpse of the affective domain of human understanding. 6 Since all three ethical perspectives are present in Willard's writings on education, a review of the major tenets of Puritan, Enlightenment and evangelical theories of cognition is essential.

At its most basic level, the official Puritan epistemology was essentially Aristotelian (i.e., all

\footnotetext{
$\sigma_{\text {The terms "cognitive, " "affective, " and }}$ "psychomotor," refer to the Bloom Taxonomy of Educational objectives. This modern instructional taxonomy divides learning theory into essentially three domains: the cognitive or mental skills; the affective or growth in feelings or emotional areas; and the psychomotor or manual, physical skills. These terms will be used throughout this paper. Benjamin Bloom, ed., Taxonomy of Educational objectives (New York: Donald McKay), 1964).
} 
knowledge is sensory in nature and there are no innate ideas). Puritan scholars, however, were constantly forced to compromise this view of man's thought processes because theirs was a God-centered universe. The purpose of Puritan scholarship was to use the God-given faculty of reason to discover as much as possible about the divine purposes of the natural world.

But there were problems with the early scholarship of the Calvinists. First, while the Puritans lauded scientific study, they also held that it was only for the purpose of uncovering God's divine plan as reflected in nature. Because theirs was a God-centered universe, Puritan teleology was bent solely to the achievement of spiritual understanding. Puritan intellectuals did employ the inductive methods of Ramus and his followers, but they were first and foremost religious in their approach to education and scholarship. 7 This viewpoint, of necessity, limited their ability to apply impartial, empirical methods to their work.

\footnotetext{
7 The influence of the French scholar, Petrus Ramus (1515-1572) on the process of education in the seventeenth and eighteenth centuries was enormous. In his two primary works, Dialecticae institutiones (Education in Dialectic) and Aristotelicae animadversiones (Remarks on Aristotle), Ramus advanced the primacy of inductive logic in the cognitive process. This process was to be central to the puritan method of scholarship and, consequently, to the history of American pedagogical theory. For a brief discussion of Ramus and American education see Cremin, American Education, The Colonial Experience, 102-5.
} 
Secondly, the Puritans' belief in the innate depravity of humanity severely limited their faith in man's ability to discover Truth. The corruption introduced by the fall from grace so diminished man's ability to discover goodness and truth that logical analysis alone could not chart a path to salvation. So while Calvinists firmly believed that the world could be understood and church and society ordered according to the laws that girded God's creation, there were definite limits to man's cognitive abilities. 8 Certain things remained "mysterious."

Finally, the Puritan belief in predestination left little room for the concept of free-will in man's pursuit of knowledge. In their quest for an ordered universe, the Puritan theologians believed that the soul of man was a "rational soul," one ruled by two faculties, reason and will. This relationship between reason and will, however, was an unequal one. Because of the original fall from grace, the will of man was an imperfect will; in fact it often misled reason. Consequently, Puritan views of the cognitive process were dominated by their religious perspective. Central as

\footnotetext{
${ }^{8}$ An excellent, brief discussion of the basic tenets of Calvinism and Puritanism in its European form can be found in Lacey Baldwin Smith, This Realm of England: 1399 to 1688 (Lexington: D.C. Heath and Company, 1988), 197-201. For a discussion of the philosophical basis for Calvinism see George Sabine, "Calvinism and the Power of the Church," chap. in A History of Political Theory, 3rd ed. (New York: Holt Rinehart and Winston, 1961), 362-70.
} 
this explanation is to Puritan educational thought, it bears further explanation.

The first faculty, that of reason, was at the center of the Puritan concept of cognition. According to Puritan thought, reason allowed man to take in information by physical sensation, which was not unlike Locke's theory of the sensory acquisition of knowledge. But here the similarity ended. Locke and later empiricists believed in the scientific actuality of these sensory impressions as reflections of reality. Puritan scholars, on the other hand, saw these "phantasms" as essentially copies of God's reality as interpreted through the imperfect filter of mankind's mind. 9 In other words, we can only know what our "corrupted reason" tells us.

The second faculty of the Puritan rational soul was the will, and this was located in the heart. The will, which directed the passions and the affections, had the power to discern between good and evil, right and wrong. Often the will would influence the reasoning mind.

Like most Calvinists, however, the Puritans distrusted this emotional side of mankind's nature. The will was

9The Puritan concept of "phantasms" is not unlike Plato's famous cave and shadow analogies, but there are some significant differences. For a discussion of Plato's thoughts on cognitive theory see, H. W. B. Joseph, Knowledge and the Good in Plato's Republic (London: Oxford University Press, 1948). 
frequently seen as being under the influence of the devil. Therefore, the "phantasms" or impressions of the world provided for the reasoning mind to interpret, were sometimes flawed and incorrect. Thus, according to puritan cognitive theory, man's reasoning mind often reaches the wrong conclusions; consequently, man thinks and acts incorrectly or immorally.

The Puritan high regard for human learning left some knotty problems unsolved. One of the most significant was how to determine the proper relationship between Truth discovered by natural reason and that discovered by scriptural study. This was essentially the legacy Calvinism bequeathed to Enlightenment writers of educational theory and, consequently, to nineteenth century educators such as Emma Willard.

This problem was also central to the Enlightenment view of the cognitive process. Freed from the restraints of Calvinist theology, Enlightenment philosophers were able to invent new explanations about how man acquired knowledge and, consequently, how he learned. At the core of these new theories were changing perceptions of the relationship between God's divine revelation and man's rational free-will. The implications of these new educational theories were overwhelming. These were new, "enlightened" ways of looking at the world. 
Englightenment Free-will, Revelation and Cognition

All nature is but Art unknown to three;

All Chance, Direction, which thou canst not see;

All Discord, Harmony not understood;

All partial Evil, universal Good:

And, spite of Pride, in erring Reason's spite, One truth is clear, WHATEVER IS, IS RIGHT.

Alexander Pope, "An Essay on Man."

Tom Paine called it the "Age of Reason"; historians have labeled it the "American Enlightenment." But whatever label is applied to the eighteenth century, it glorified the rationality of man. From the God-centered universe of the Puritans, western civilization quickly moved toward one which had at its center the logical, thinking human being. This new perception, of necessity, redefined predominant views concerning the very nature of mankind. Gradually the conviction began to take hold that man was neither blessed nor evil but simply neutral; John Locke's famous "blank slate. "10

This view of human neutrality, however, posed some interesting dilemmas for both religious and educational

${ }^{10}$ It should not be forgotten that John Locke was also a man of his times and his theories of rationality and education were heavily influenced by the political situation in England in the late seventeenth century. Locke's underlying motivations have been a constant source of historical debate between scholars such as Richard Ashcraft and Peter Laslett. An interesting recent article which makes this point is Richard Ashcraft and M. M. Goldsmith, "Locke, Revolution Principles, and the Formation of Whig Ideology," The Historical Journal 26 (December 11983): 773-800. 
theorists. The most central conflicts, once again, concerned just exactly what went on in the mind of man. If, as Enlightenment thinkers initially asserted, man was simply a neutral agent in the learning process, how then did he reason? Was thinking divine revelation or was it a skill to be learned through determined study? Might man be an active participant in the learning process or must he simply react to external stimuli? Most critically, if man created his own thought, where then was the place for God's revelation? These were fundamental and troubling questions. Part of the problem lay in the varied ways in which the term "rational" was understood. As the thoughts of the European Enlightenment filtered into the American mainstream the definition of reason was broadened. The meaning of the word was not as restricted as it is in modern usage.11 For some eighteenth and early nineteenth century educators, reason was an encompassing term which referred to all natural sources of knowledge, especially the logical, empirical, mathematical and scientific. For others, reason also

\footnotetext{
${ }^{1} 1_{\text {The }}$ reading materials of the Enlightenment came to American libraries in varying stages. Americans were not immediately inundated with this literature. Lundberg and May have divided these literary incursions into four periods: 1700-1776; 1777-1790; 1791-1800; 1801-1813. David Lundberg and Henry F. May, "The Enlightened Reader in America," American Quarterly 28 (Summer 1976): 292-94.
} 
referred to the process by which man thought. 12 For many this implied that the rational process could be taught and thus God's purposes understood.

There was further tension, however, between the religious view of cognition as divine revelation and these new, secular views of reason. Could God's will and man's reason exist side by side in the mind of man? John Locke proposed a solution. Reason, he stated, must be the judge of true revelation. Man needed criteria for distinguishing between what was true and what was false revelation; only reason could supply the proper criteria. The Lockean position did not reject divine revelation but it did claim that mankind's free-will allows him to discern between God's true purpose and simple emotional enthusiasm. This was a radical new way of looking at the human cognitive process. 13

12 The close connection between religion, logic and philosophy can be seen in the way in which educators titled their school course offerings and textbooks. At the Troy Female Seminary the 1843-44 school catalogue tells the parents of prospective students that their daughters will be instructed in "The Philosophy of the Mind," and "Natural Theology" and "Evidences of Christianity and the Bible." Further, "The Institution is furnished with a valuable Library and extensive Philosophical 'Apparatus', . . ." Catalogue of the Officers and Pupils of the Troy Female Seminary for the Academic Year, Commencing March 8,1843 , and ending February 21,1844 i together with the conditions of admittance, \&c. (Troy, New York: N. Tuttle, 1844), 14-15.

13 The claim for the free-will of the mind was not unique to John Locke but he was one of the first to apply the concept to educational theory. "Arminianism," and "freewill" had come to be almost synonymous in America by the early eighteenth century. Anyone who embraced the central 
Revelation must be judged of [sic] by reason. . . . God, when he makes the prophet, does not unmake the man. He leaves all his faculties in the natural state, to enable him to judge of his inspirations, whether of divine origine or no. . . . Reason must be our first and last judge in everything. I do not mean that we must consult reason, and examine whether a proposition revealed from God can be made out by natural principles, and if it cannot, that then we may reject it: but consult it we must, and by it examine, whether it be a revelation from God or no [emphasis mine]. 14

Some democratic, enlightened thinkers in America went even further than Locke and rejected the concept of divine revelation altogether. They simply replaced revelation with reason. Their God became a rational one. To men such as Thomas Jefferson, "God [was] the supreme craftsman who had in the beginning set in motion laws which governed the universe and all that inhabited it."15 once set in motion, however, this rational God had little to do directly with the workings of the mind of man.

The friction between spiritual revelation and rational thought gradually moved, if not towards synthesis, at least towards an uneasy compromise. The moral truths of the world

Arminian belief that man's salvation was at least partly dependent upon the free acceptance of Christianity was labelled a believer in "free-will." The Episcopalians embraced the concept of free-will with a vengeance. Emma Willard belonged to the Episcopal Church all her adult life.

\section{John Locke, The Collected Works of John Locke vol.} 3 (London: Thomas Tegg, 1823), 156.

15 Jennings I. Wagoner, Jr., Thomas Jefferson and the Education of a New Nation (Bloomington: Phi Delta Kappa Educational Foundation, 1976), 18. 
might still be discovered in the Scriptures, but (unlike the Puritans) Enlightenment thinkers saw man as capable of explaining them by reason. Empirical science gave him the method, and free-will unleashed his mind. If man studied hard enough, he had the power to uncover God's plan.

The impact of this belief in human self betterment was enormous. Gone was the tyranny of unexplained revelation, accepted on faith, unquestioned and obeyed. Gone was the Puritan view of the mind as a reflection of the "corrupted soul." In its place was a free man, one who held his educational destiny in his own hands and who could grow to be more like God through science and logic. Enlightenment philosophers knew that religion could enslave the mind. "I have sworn upon the altar of God [Jefferson wrote], eternal hostility against every form of tyranny over the mind of $\operatorname{man} . " 16$

There is little debate that Enlightenment philosophy influenced social, cultural, economic and political institutions at a critical time in America's development. This new rationalism, after going through various philosophical modifications, also left a significant imprint upon nineteenth century educators. For the purposes of this discussion, the most significant implication of this emerging 
secularism was that it spawned a desire among educational theorists, scientists and philosophers to determine exactly how the human mind learned. By understanding the human cognitive process (what would today be called educational psychology), it was held that classroom curriculum and instructional method could be designed literally to train people to think. Scientific method could be applied to the discovery of the laws of cognitive theory. Schoolchildren could be the benefactors of rational thought. Educators rushed to explore the hidden workings of the mind of man. It was this same enthusiasm for the psychological dimension of human learning that Emma Willard inherited, at least in part, through the American disciples of the Scottish Common Sense Realists. Their thoughts were to be central to her personal epistemology.

\section{Piety, Emotionalism and Education}

"Spiritual understanding consists primarily in a sense of the heart of that spiritual beauty," wrote Jonathan Edwards in 1746. "When the mind is sensible of the sweet beauty and amiableness of a thing, that implies a sensibleness of sweetness and delight in the presence of the idea of it: and this sensibleness... . carries in the 
very nature of it the sense of the heart."17 In these words Edwards intellectualized the feelings of many of his countrymen. As the cold hand of Enlightened rationality tightened its grip on the spiritual lives of eighteenth century Americans, a great groundswell of fear and longing began to appear. It seemed to the average American that man's emotional needs were being sacrificed to a God made of machinery.

Although Newton had shown that natural phenomena could ultimately be proven by universal laws, it rapidly became apparent that there would be little need for spiritual agents in this brave new world. "It was not because Newtonian science denied religion that it was dangerous; it was because it rendered religion unnecessary. Understanding and control of nature were possible without recourse to God."18

Partly in answer to this emotional sterility, a great wave of evangelical piety began in the Protestant churches of Europe and Great Britain in the seventeenth and eighteenth century. The movement quickly spread to American shores. With the arrival of the famous revivalist preacher George Whitefield late in 1739, the "First Great Awakening" of

17 Jonathan Edwards, "Treatise Concerning Religious Affections," The Works of Jonathan Edwards in Four Volumes vol. 1 (New York: Leavitt, Trow and Company, 1849), 112-13. America, 167.

18 Flower and Murphey, A History of Philosophy in 
religious evangelism was launched on a scale that embraced most of the colonies.

While the various interpretations differed slightly from one denomination to another, the central and unifying theme of this new pietism was that true Christian existence resulted from an inner, personal relationship with God. Authentic Christianity came to be seen as one in which all theology, worship, and good works made no difference unless this personal awareness of God existed. Revelation, it was held, came as a divine light from above. Through the process of personal conversion this divine light could shine into each individual soul. There was hope again. Several of the major reasons for this "Great Awakening" in the mid-eighteenth century have been noted previously: the rapid breakdown of the old puritan belief systems, the rationalization of God, and the growing gap between traditional ideals and economic reality. The common man, faced with a quickly changing and expanding world which he could barely understand, badly needed a spiritual credo which was alive, comforting, and meaningful. Neither the determinist God of the Calvinists nor the rational God of the Deists fit the bill, but evangelical piety did.

The "First Great Awakening" was not simply a religious movement, however. It was also intertwined with virtually every significant social, philosophical and intellectual 
question of mid-eighteenth century America. It is not surprising, therefore, that educational ideas, attitudes, forces, and institutions should have been at the center of the storm.

From the very beginning this new "Awakening" had educational ramifications. There appear to be two possible reasons for this. The first is found in the history of Calvinism and Puritanism noted earlier in this paper. When writers such as Cotton Mather and later Jonathan Edwards took up their pens to defend Calvinist doctrine in the face of scientific heresy, they did so within a tradition that found scholarship the logical avenue of expression.19

Another factor appears to be of equal importance. Educational institutions are always powerful vehicles for propagating ideas and disseminating cultural imperatives within the social structure of any state. The clergy of eighteenth century America understood this and manipulated the system accordingly. This manipulation implied another dimension as well; whoever controlled the classrooms of the community, controlled not just the minds of those within, but

19 "Certainly there can be no quarrel with the proposition that the metropolis contributed the original supply of educated men: that is in the nature of colonization. What is especially interesting with respect to the American situation was the extraordinary concentration of educated men in the Great Migration of Puritans to New England." Cremin, American Education, The Colonial Experience, 207. 
also an important portion of the available economic, social and political resources. These were opportunities not to be passed over lightly by a profession seemingly in rapid decline.

Most of the ideological warfare took place in the churches of New England. When the battle lines were finally drawn, they were drawn around three major issues: the conversion experience itself; the integrity of unconverted ministers; and the popular practice of itinerant preaching. 20 On one side were the anti-revivalists (termed "Old Lights" or "Old Side"), men deeply repulsed by what they saw as the excessive emotionalism, lack of proper decorum and generally overpowering "enthusiasm" of the newly converted. On the other side were the pro-revivalists (termed "New Lights" or "New Side"), men who welcomed the emotionality of this new religious experience with all its democratic, egalitarian implications.

These seemingly undignified religious squabbles quickly gained educational significance. At the base of it all, once again, lay the conflict between the rational mind and the

20 The possibility that men could preach without going through the traditional conversion process (as sanctioned by the established churches), quickly became a point of great contention between the revivalists and antirevivalists. For a discussion of this problem and its educational impact, see Sloan, The Great Awakening and American Education, 14-20. 
emotional will. The excessive displays of weeping, shouting and fanaticism exhibited during revival meetings led many a conservative ideologist to question the very sanity of those who went through this new, personal conversion. Revelation, they felt, was a thing to be analyzed, studied, measured and judged, but not experienced. How could a rational, progressive society educate these wild-eyed heretics who were running around loose?

For these same conservative thinkers, the men who preached to these huge, outdoor gatherings often appeared more uncouth than their followers. Many "Old Lights" viewed itinerant preachers as little more than opportunistic showmen. Further, because personal conversion in the traditional Calvinist sense was not a requirement for obtaining a position as a revivalist minister, the academic qualifications of these men soon came under attack. One of the main criticisms launched against the "New Light" ministers by the "Old Light" clergy, was that they were antiintellectual.

By placing so much emphasis on emotional revelation, traditionalists argued that revivalist teachers necessarily precluded reasonable understanding. A proper religious leader, conservatives held, should not permit these unseemly displays of emotion to interfere with the serious business of man's spiritual education. Religion was not a carnival side- 
show. This entire revival process, they felt, was positively in bad taste. "There never was a time, in this land, [wrote Charles Chauncey] wherein there was such flocking after some particular ministers, and glorying in them as though they were GoDs rather than men." 21

Forced out of the mainstream of the educational establishment, the revivalists built their own schools, colleges and academies, or infiltrated others through faculty, administration and curriculum. Princeton University, Brown University, Rutgers and Dartmouth all were products of revivalists' educational efforts, either directly or indirectly. At first using only "Log Cabin colleges" to train their ministers, the ideological influences of the First Great Awakening were eventually, and rather circuitously, to connect with the Scottish Common Sense Realists to greatly modify several major American academic institutions. 22

Ideological defenders of the Great Awakening, however, had their work cut out for them. In the face of a world

21 Charles Chauncey, Seasonable Thoughts on the state of Religion in New England, n.p. (Boston: 1743), 2-3. See also "The Colonial Colleges and Free-Thought," chap. in Riley, American Thought, 57-68.

22 "Log Cabin Colleges" were the first educational institutions established by revivalist preachers in order to train future ministers. The first of these colleges was set up by William Tennent in the 1720s. 
which glorified reason, how could one defend the value of emotion in the religious experience? How could one combine Calvinist determinism with spiritual free-will? To antirevivalists such as the Reverend Charles Chauncey, of First Church, Boston, there could never be an integration between the cognitive process of reason and emotional irrationality. "There is the religion of the understanding and judgement and will," Chauncey wrote, "as well as of the affections; and if little account is made of the former, while great stress is laid upon the latter, it can't be but people should run into disorders. $" 23$

Jonathan Edwards, a brilliant Calvinist theologian, took up the defense of revivalist education. As Edwards struggled to combine Lockean epistemology, Puritan Calvinism and Newtonian logic he inadvertently bequeathed to nineteenth century educators a more integrated understanding of man's nature. Far from being the subordinate force pictured by Locke and Chauncey, the very direction, quality and process of human thought was, according to Edwards, grounded in the emotional side of man's nature.

In his attempt to synthesize Lockean psychology, based upon the sensory acquisition of knowledge, with the religious principle of emotional, spiritual revelation, Edwards

23 Charles Chauncey, Enthusiasm Described and caution'd Against, n.p. (Boston: 1742), 3 . 
provided educators with the first step in their understanding of the affective domain of human learning. He did this by expanding the Lockean definition of "simple ideas" to include not only sensations born of physical stimuli but also those images which are born of emotional sensibilities.

While still basically a disciple of Calvinist determinism, Edwards opened the door to the possibility of innate conceptualization. He drew a critical distinction between speculative and sensible knowledge of internal, or spiritual things. As to "the former [it]. . consists in mere speculation or understanding of the head . . . i.e. all that understanding of things that don't consist in or imply some motion of the will, or, in other words (to speak figuratively) some feeling of the heart, is mere speculative knowledge. . . ."24

Sensible knowledge, however, is "that which consists the sense of the heart." This category of knowledge consists of

all that understanding of things that does consist in or involve such a sense of feeling, . . . all ideal apprehension of beauty and deformity, of loveliness and hatefulness; and all ideas of delight or comfort, or pleasure of body or mind. . All knowledge of this sort, as it is of things that concern the heart and will, so it

24 Jonathan Edwards, Jonathan Edwards: Representative Selections, ed. Faust and Johnson (New York: American Book Co., 1935), 119-20. See also Douglas Sloan, The Scottish Enlightenment and the American college Ideal, (New York: Teacher College Press, 1971), 48-49. 
all relates to the good or evil that the sensible knowledge of things of this nature involves. And nothing is called a sensible knowledge on any other account but on the account of the sense or kind of inward tasting or feeling of sweetness or pleasure, bitterness or pains, that is implied in it or arises from it. 25

For Jonathan Edwards the emotional side of the cognitive process had a validity separate from the literal, analytical world of Locke. Edwards held that the mental processes were influenced by the interplay between emotional imagery and affective conceptualization. Mankind's emotional nature gave his ideas a glory independent of cold reason. The light of divine revelation became the light of rational understanding, and the objects of our sensibilities were as real as a mountain, ocean or tree. In this belief Edwards was not unlike Emma Willard, who also placed great value on the integration of the emotional aspect into the learning process.

Just after Willard was born, America was rocked by another wave of religious intensity or "Second Great Awakening." Still marked by spiritual enthusiasm and emotional conversion, prominent revivalists such as Charles Finney again placed an emphasis upon the free agency of mankind in the religious experience. 26 But this time the

\section{Ibid.}

26 Jonathan Edwards, A Careful and Strict Enquiry into the Modern Prevailing Notions of the Freedom of the Will, which Is Supposed to be Essential to Moral Agency, Virtue and Vice, Reward and Punishment, Praise and Blame, ed. Tomas Ramsey (New Haven: Yale University Press, 1957). 
message was much more democratic in nature, less hemmed in by ideological nit-picking and semantical arguments than earlier eras. The evangelical spirit now moved outward to reform society as well as the individual. This sense of a divine crusade easily fit America's vision of itself as a Christian nation chosen by God to reform the world. For progressive educators such as Emma Willard, education was the proper social institution to carry out this spiritual mission.

\section{Religion, Reason, and Education in the Mind of Emma Willard}

The educational thought of Emma Willard bears the distinct imprint of Puritan wisdom, Enlightenment rationalism and revivalist emotional piety. While there are many examples in Willard's writings on education which support this statement, the most outstanding evidence lies in her work entitled Morals for the Young; or, Good Principles Instilling Wisdom. 27

In this area, in particular, the historian must proceed with caution. Like much of Willard's work, Morals for the Young, is not a consistent, logical document. It was meant to be a children's guide and was written for instruction not analysis. Neither was it meant to be a static description of her religious position. As with all of us, Emma Willard's 
religious and philosophical beliefs grew and changed over her lifetime. The task of establishing her exact position on religion, reason, and education, therefore, must be an inferential one.

Certain obvious deductions can be made, nevertheless. First of all, the educational philosophy of Emma Willard has at its core the basic tenets of Puritan wisdom. The purposes and ends to which learning should be directed, the position of God's mysterious will in the operations of the mind of man, the omnipotence of God in nature, and her belief in an essentially imperfect human soul, all place her squarely within the American Calvinist tradition. But it is a Calvinist light diffused through a prism of reason, emotion, and hope.

At the fulcrum of Willard's spiritual world was the allpowerful God of the Calvinists. "The soul of the universe is God. All matter obeys his will. He is infinite in power."28 But like the revivalists, Willard's God (while capable of causing "the wicked to receive the reward [punishment] of their evil deeds") was mostly a God of love, a more personal God. "When men, assisted by the Holy Spirit, open the full eye of faith, and discern the ineffable love of God in 
Christ, then are their hearts moved to give in return a deeper and a warmer love to God their Redeemer, . . ."29 According to Willard, man's spiritual connection to the omnipotent but loving God was through the "invisible reality" of the human soul. The soul is, by its very nature, unable to be seen by the human eye. But as with Puritan wisdom, there was always visible evidence of God's invisible design if one just looked for signs. Just as the Puritans had believed that for any life to exist it must have a soul, so for Emma Willard the outward movements of the body seemed proof enough of the soul's existence. Willard maintained that "every one has a soul, which governs the body, and by which the body's actions are performed."30

For Emma Willard the human body was more than just the outward manifestation of the human soul, it was also the instrument by which the mind gained knowledge. Put another way, in order for man to understand what to do, he must first understand what is or what should be. This was the function of the mind. Thus in Willard's view of the cognitive process, religion and cognition were bound together. The mind and the soul were synonymous and the process of knowing two-fold.

29 Ibid., 116.

30 Ibid., 24. 
The mind, or soul, is, as we have shown, an invisible reality, the tenant of the body. The body is its instrument, in a double sense. In the first place it is, through the instrumentality of the body (by the senses), that the soul, or mind, gains its knowledge of all outward things; and second, it is by means of the body, that the soul, or mind, acts upon all the outward things within its power, including the body itself. In this second sense of the action of the mind upon outward things, man does good or evil, according as wisdom or Folly prevails in his mind; but in order that the mind should become wise, it must have knowledge of Truth, which is gained through those inlets to the soul, the senses of the body. 31

Having established the religious basis of cognition, willard proceeded to look deeper into the operations of the mind. In doing so, she ran into the same duality of reason and will which had bothered earlier thinkers. It is in the concept of man's free agency that Emma Willard first permanently parts company with her Puritan ancestors.

\section{Free-Will, Reason and Emma Willard}

In the Calvinist doctrine of predestination there had been little room for man to act without God's direction; man was indisputably depraved and damned for all eternity. But by the time European Enlightenment philosophy had arrived in America and religious revivalism had transformed the spiritual sense of the country, this belief had changed vastly.32 Individual "free-will" had generally come to be accepted as one of mankind's "inalienable rights."33

31 Ibid., 43.

32 "The Calvinist theory of predestination had nothing in common with the modern conception of universal 
For Emma Willard the connection between free-will and the human cognitive process was critical. Although Willard still accepted the argument that "man can only control his Will, mind and his body, according to certain laws, which God himself constantly maintains," she was too much a child of the American intellectual tradition to return to the mental straight jacket of Calvinist predestination. 34 what Willard provides for the twentieth century reader is one woman's attempt to synthesize a diverse polyglot of varied epistemologies. Her arguments are, therefore, sometimes rather convoluted and often conflicting.

She first argued that the thoughts of man are different from the thoughts of God. God's Will is definitely at the top of the moral order; but after God has spoken, Willard held that it was up to each man to choose to listen. Carefully defining "the will" as "a certain part of the mind, which is the commanding power of the whole man," willard

causality. It was rather a belief in a cosmic system of quasi-military discipline." Sabine, A History of Political Theory, 364 .

33 Thomas Jefferson, who was himself a Deist, was quite clear about the issue of free agency as an inalienable right. As one author has put it, "Religion, for Jefferson, was strictly a private affair. Not so private nor to be tolerated were structures, religious or political, which infringed upon the right of free men to think for themselves." Wagoner, Thomas Jefferson and the Education of a New Nation, 19-20.

34 Willard, Morals for the Young, 85. 
clearly placed the ultimate control of the cognitive process under the decision of the individual.

Man's Will is always rightfully subject to God's Will; but otherwise, it is by nature the ruler of his own mind and body [emphasis mine]. In regard to his mind, . . . under God, the will is the ruler of the man. To do a thing voluntarily, is to do it by the act of the will.35

Willard's argument for human cognition tried to combine elements of both free-will and Godly omnipotence. It can be recapitulated as follows:

1. God is the center of the universe.

2. His laws are unchangeable and often unfathomable by the human mind.

3. The connection between the will of God and the will of Man is the soul.

4. The soul is synonymous with the human mind.

5. Human Will is the commanding portion of that mind.

6. Within the realm of God's law, Human Will (and thus the human mind) is a free agent.

7. Therefore man's reasoning powers are his own.

Thus for Emma Willard,

The will is then the Ruler of the human being, subject only to the nature of the will of God. And it is the highest ownership and privilege of man to govern his own mind and body, subject to no control but such as springs from the laws of God. 36

"Man's moral nature proves that he is a free agent; that is, free to do, whatever God requires him to do."37

The last of the great Puritan divines, Jonathan Edwards, could not accept the concept of free-will, "for there is in

35 Ibid., 86.

36 Ibid., 87.

37 Ibid., 90. 
the nature of faith [Edwards wrote], a sensible acknowledgement of absolute dependence [emphasis mine] on God . . . "38 This was a view of mankind which Emma Willard obviously did not accept. It was not the supremacy of God which Willard debated; it was man's absolute dependency upon the will of God which Emma Willard rejected.

Willard's advocacy of man as a free agent places her decidedly at odds with Puritan teleology. Closer to the epistemology of John Locke and the moral egalitarianism of the revivalists, Willard's view of the cognitive process is a far cry from Calvinist determinism.

Man is, as we have seen, capable of good and evil actions; and although God wishes him to choose the good, yet He will not force him; for this would be to violate the dignity of his free-agency, and make him a mere machine. 39

Man, guided by God, was ultimately responsible for his own thought processes. The problem was how to determine what God wanted him to learn.

Revelation, Reason and Emma Willard

Willard's answer to the question of how man should use scholarship in achieving the moral purpose God had intended is found in her view of revelation. According to Willard,

38 "Freedom of the Will," chap. in Jonathan Edwards, Jonathan Edwards: Representative Selections, 228-29.

39 Willard, Morals for the Young, 93. 
there are two ways in which God teaches man how to apply the reasoning powers of the mind. The first is direct revelation. It is found in the scriptures and is the definitive word of God. Indirect revelation is found in the "light of nature" or the intellect. This type of cognition is indirect understanding and is found through man's "reasoning powers." In her interpretation of revelation, Emma Willard had links to two men who were among the major transitional philosophers between Calvinist teleology and Enlightenment deism. These two men were Samuel Johnson and Jonathan Edwards.

In his subjection of revelation to reason, samuel Johnson ultimately embraced an idealism founded upon an uneasy relationship between divine and rational. Appalled by Deism, Johnson argued that by embracing the full implications of unrestrained reason, man stood in danger of cutting himself from God entirely. In the end, Samuel Johnson was able to relegate the benevolence of the spirit to the divinity and subdue reason to revelation.

Jonathan Edwards also held that there should be a subjugation of reason to revelation. In his writings, Edwards holds that the "light of reason," although still shining through in the mind of man, did not shine very brightly. Even though he synthesized Puritan theology with 
Enlightenment rationality, Edwards held fast to the Calvinist belief in the corruption of man.

Edwards further argued that many of the divine truths which were necessary for Christian belief could no longer be discovered by man's natural reason alone. Unlike the Deists, Edwards felt that many of the messages in the scriptures were not open to rational interpretation and that they required the divine light of revelation. Revelation was the giving of new truths to man, not by reason, but through inspiration. Reason and revelation were compatible in Edwards thought, but they were not one and the same thing.

For Emma Willard, reason and revelation were also closely connected. But most importantly, willard also held that rationality could not be the only way to discern the will of God. Since the doing of God's will was the ultimate purpose of wisdom, revelation and reason both had a place in Willard's cognitive theory. Revelation assisted the reasoning mind in determining exactly what to study and how to determine what is morally right or wrong. Willard's belief in the necessity of revelation indirectly connects scholarship and religion. According to willard,

The four greatest Lights given by God to man (all showing the Will of God, and the Way of Wisdom), are, I. The Light of nature, or the Light of TRUTH in the understanding. . . . II. The Light of DIVINE REVELATION, or the HOLY SCRIPTURES, of the revealed will 
of God, IV. The Light of CHRISTIAN LOVE in the renewed heart. 40

Through the Light of Nature, Willard argued, man has understanding and reason. But like Edwards and others, Willard could not tolerate the full implications of a cognitive process in strictly rationalist terms. "God has given to man Reasoning Powers, . . but he wants clearer knowledge. . . Yet the Light of Nature cannot give that positive assurance which we need, in order to form a sound judgement, and make wise calculations to guide us concerning true wisdom in conduct. God has then made man's intellect [emphasis mine] so that he needs a Revelation."

Clearly according to Emma Willard, the will of God cannot be known through the use of reason alone; direct revelation was needed. "God has given to man a rational, reflective and calculating power called Reason, or Understanding, by which when he has learned the Truths on any subject, he can discern what is man's true interest therein; . ." Willard wrote. But "God has [also] made man's soul [or mind], both in the intellectual and moral departments, to need a Direct Revelation."41

Finally, the spirit of Christian love and benevolence that moves quietly through the works of Emma Willard was the

40 Ibid., 96 .

41 Ibid., 105, 107. 
same as the reforming love of the evangelists. Willard envisioned a personal love of God, one which can only be reached through individual experience and introspection. It was not the condemning God of the Calvinists, but a loving and reasonable God who taught man the right way to think and live. Willard's God was the rational God of the Deists softened by the quietist beliefs of the revivalists, one perfectly suited to the progressive but not radical mind of Emma Willard.

While Willard's sense of decorum would not have permitted the more emotional displays of revivalist piety, she did believe that Christian conversion was necessary for true knowledge and understanding. Like the revivalists, Emma Willard's definition of conversion was inner directed and personally experienced. 42

Turn, then, to him with a penitent heart and have true faith. Into the invisible, mysterious chambers of your

42 The entire topic of conversion, feminism and evangelical missionary work is a fascinating one which cannot be adequately covered here. Several excellent articles have been written on the subject. Among the best are: Nancy F. Cott, "Young Women in the Second Great Awakening in New England," Feminist Studies 3 (Fall 1975): 15-29; Mary P. Ryan, "A Women's Awakening: Evangelical Religion and the Families of Utica, New York, 1800-1840, American Quarterly 30 (Winter, 1978): 602-23; Barbara Welter, "She Hath Done what She Could: Protestant Women's Missionary Careers in Nineteenth Century America, "American Quarterly 30 (Winter 1978): 624-38; and David S. Reynolds, "The Feminization Controversy: Sexual Stereotypes and the Paradoxes of Piety in Nineteenth Century America," New England Quarterly 53 (March 1980): 96-107. 
soul, where selfishness has ruled-and where, as the Scriptures inform us, an Evil Spirit has sought to draw you away from God-there, He will send another, . . who will change your hard heart, so that Christian Love shall enter in and there abide. This is CONVERSION; . . .43

In this quiet, almost personal relationship with God is found the true meaning of scholarship for Emma Willard. "We should feel our need to be instructed, so that we might certainly know what is pleasing, and what is displeasing to Him; and we should, therefore, thankfully receive every Light which He has vouchsafed to give use, to lead us into the way of true Wisdom,-especially the Light of his direct

Revelation." 44

In a gentle and loving way, Emma willard strove to teach her students the meaning of God's word, the ways of Christian morality and the pietistic nationalism of her growing country. In her educational philosophy, Puritan Calvinism, evangelical love, and Enlightenment rationalism, once again, found themselves in the same uneasy relationship. Willard had little success in solving the dilemma of reason, emotion, and religion. But her thoughts do echo the paradox which has troubled great educators for centuries.

Evidently untroubled by these problems, Emma Willard was content with her own personal synthesis of the divine and the secular. With this intellectual systhesis as an underpinning

43 Willard, Morals for the Young, 117.

44 Ibid., 134. 
for her thoughts on childhood learning, willard developed her own personal pedagogy. 


\title{
CHAPTER FIVE \\ EMMA WILLARD'S EDUCATIONAL PHILOSOPHY: ANALYSIS AND CONCLUSION
}

\author{
The Place of Emma Willard in the History of Education \\ Few historians will question the fact that the years \\ stretching from the late eighteenth to the early nineteenth \\ century marked a period of significant cultural change in \\ America. The Industrial Age, ushered in by a new-found faith \\ in science and technology, provided many Americans with a \\ better standard of living and increased opportunities for \\ personal advancement. As an aggregate, these economic \\ changes were generally viewed in a positive light by \\ contemporary society and also by succeeding generations. \\ While it is true that industrialization did better the \\ overall material conditions in America, it did so at a cost. \\ The rapid economic growth caused unforeseen problems. \\ Terrible slums developed in the shadow of magnificent Park \\ Avenue mansions; children as young as six and seven worked \\ fifteen and sixteen hours a day harnessed as beasts of burden \\ in factories and coal mines; and men, women and children died \\ by the score as the result of overwork, disease and \\ malnutrition.
}


It was not only in the realm of economics, however, that early nineteenth century man came under assault. Intellectually his world was first blown to bits and then reconfigured in new and often conflicting ways. Cut loose from the stable, rural environment of the early eighteenth century, America's people struggled to make sense of the rapidly changing world around them.

Intellectuals, religious leaders, philosophers, and social activists all labored to find a pragmatic solution to the clash between traditional values and economic reality. Nowhere is this pragmatic approach more apparent than in the thoughts of American writers on education during this period. For the modern reader, their work presents a microcosm of the primary conflicts and problems faced during this formative time in America's history.

As critical works in the history of education in the United States during this period, the writings of Emma Hart Willard are representative of the transitional tension which existed in the society as a whole. While there is no lack of laudatory testimony to the positive impact Willard's actions had upon the development of higher intellectual standards for women, as a spokesperson for her entire era, her educational writings justified further examination. This is the perspective which has been adopted in this paper. 
In spite of a renewed interest in the contribution of women in the field of education, recent histories have tended to focus exclusively upon either the biographical or feminist aspects of Willard's life and work, often making her into a figure larger than life. On the one hand, such distortion may represent the simple historigraphic shortcoming of taking the claims of reformers such as willard and her contemporaries at face value without proper assessment. This perspective has the obvious pitfall of making Willard's work seem unique or more unusual than the history of the nineteenth century can support.

On the other hand, it also represents a problem which may be peculiar to the writing of women's history. In an attempt to make up for lost time, writers of women's history have often been guilty of singling out the most radical actions of their earlier sisters, imbuing them with modern feminist motives and distorting the evolutionary nature of their work.

This last point is particularly true of the more pragmatic educational reformers such as Emma Willard. Women who walked that narrow path between the acceptable nineteenth century female role and the more radical actions of feminists seem the most impervious to impartial historical evaluation. Because these women felt that they could most effectively accomplish their goals by working "within the system" rather 
than challenging it head on, they were forced to use whatever method or tactic proved most effective. Consequently, to the modern reader the words of these female educators may often seem contradictory and their actions self defeating. But they were, like many of their fellow Americans, simply pragmatic and their writings reflect this pragmatic approach.

The impact of Emma Willard's writings and works can only be fully appreciated if one views the history of education as an evolutionary process in which ideas constantly change and adapt to the realities of new situations. Too often feminist intellectual history has been portrayed as one of sudden transformations or changes in institutional forms which owe their character to the single-minded determination of individual players. This viewpoint threatens to isolate the contribution of extraordinary women such as Emma Willard rather than facilitate their integration into mainstream historical scholarship.

While modern, educated women do owe a significant debt to the individual achievements of pioneers such as Emma Willard, one should remember that Willard was also a product of an intellectual, social, religious and philosophical milieu. More than an advocate of female education, she was also an American patriot, a deeply religious Christian and a scientific rationalist. In her educational philosophy she was aware of the tensions below the surface. 
The period in which willard lived and worked was a time of ideological transition and conflict. Enlightenment rationality seemed to have freed man from the fetters of Puritan damnation, but it also posed profound questions about the relationship between man and God. Modern science and technology gave nineteenth century men and women greater economic prosperity, but it also unsettled their personal relationships and social roles. Immigration and continental expansion gave the citizens of the United States a larger view of the world, but many continued to see cultural diversity as a threat to the "American way of life." It was a time of high excitement and of terrible anxieties.

The importance of Emma Willard's educational philosophy lies not only in the progressive role she played in furthering female learning, but in the fact that her thoughts provide a window on the predominant philosophical, social, economic, and religious conflicts debated at the time. As such, her educational philosophy tells us much about the era in which she lived.

Like many of her contemporaries, Willard's philosophy had at its core an unshakable belief in reason, science and progress. Her definition of rational, as has been shown, was essentially a Lockean one. Using this inheritance from the European and American Enlightenment, Willard saw the world, at least in part, as a place in which man could use his 
reason to better himself and society. Her writings on education display an unswerving faith in the perfectibility of mankind and a certainty in his ability to use institutions to determine, chart and control his progress. Men and women, Willard held, were not powerless in the face of God and nature. Reason gave them the power to change their world. Her fundamental appreciation of education also reflected nineteenth century America's growing belief that schools should be the principal means of turning educational progress into social and economic betterment. Thus, at Willard's Troy Female Seminary her students' curriculum was heavily weighted toward science, higher mathematics and philosophy, all subjects which Willard and her contemporaries felt strengthened the mind's rational powers.

Once educated, Willard's students assisted in the creation of a society which was God-ordained and progressive; one which was a logical expression of aggregate, enlightened reason. Combining a Puritan sense of duty with an awareness of their democratic responsibility, Emma Willard and her contemporaries demanded that even America's youngest citizens play a part in the growth of the new republic. To participate in the great democratic experiment these children needed to be educated; this applied to everyone, both male and female. 
Willard's faith in progressive betterment through science and reason also affected her views on women and education. In her attempts to demonstrate that women could be educated to think rationally, willard pushed at the edges of female respectability in the early nineteenth century. When she presented her Plan for Improving Female Education ${ }^{1}$ in 1819, there can be little doubt that she was slightly ahead of her time. But the philosophical process which led her to justify her stand on this issue can in all probability be seen as a natural extension of the basic Enlightenment beliefs pointed out earlier. The rest of the world was rational, so why not women?

But all was not reason. It must also be remembered that Emma Willard was, in part, a woman of the late-eighteenth century in terms of her beliefs as to the purposes for providing women with improved education. Willard's philosophy of education and her ambitions for her students and teachers consistently stress the themes of Republican Motherhood. Combining the post-Revolutionary republicanism of her youth with the Evangelical teachings of the second Great Awakening and the emotionalism of the Romantic movement, Willard defended her progressive stand for an

IEmma Willard, An Address to the Public: Particularly to the Members of the Legislature of New York, Proposing a Plan for Improving Female Education (Middlebury: J.W. Copeland, 1819). 
educational system that would, when realized, fit comfortably within the ideological limits of her generation and gender. As the mothers of future American citizens, Willard's educated women had a special role to fill. Her educational philosophy also incorporated tenets of mainstream Christianity. Willard held that the purpose of education, for both men and women, was the glorification of God and the betterment of society. As has been discussed earlier, however, this position created several uneasy arrangements between benevolent Christianity and Enlightenment rationality. It was the continuing conflict of Christian spirituality with the "cold, hard light of reason" which produced the fundamental ideological tensions with which early nineteenth century western civilization never quite came to grips. Emma Willard was no different in this respect, as her writings note.

One of the areas in which this conflict is most apparent in willard's writings is in her views on the proper social role of the educated woman. Women, willard felt, had a special duty to God to use the "talents" he had given them to create a morally upright society. In her educational philosophy, Willard believed that the proper private role of educated women was as Christian wives and mothers. In this belief, Willard echoed a fundamental middleclass nineteenth century ideal. The social contribution of 
women as direct moral and spiritual guardians of their individual families, and as the indirect embodiment of virtue in society at large, was not radical or feminist in the least. At the time, this seemingly conservative viewpoint was seen as critical to the stability of a growing country. Indeed, it may be argued that a virtuous mother at the center of the family is still an important value to Americans. While softened and modified considerably over time, such belief still pervades certain parts of American culture today. 2

Like the majority of respectable middle-class reformers, Emma Willard also shied away from advocating the total equality of the sexes. By assuming that women, while rational, were not the equal of their male counterparts, Willard justified the expense of public funds for female education on the basis of patriotism, social morality and economic necessity. Her arguments, which eventually came to be accepted by the majority of Americans, provided the underlying philosophical justification for her

\footnotetext{
${ }^{2}$ Nancy Cott, Barbara Epstein and others have, of course, justifiably pointed out that this rationale was developed by men as a means of "social control" of women. This argument has great validity. See Nancy F. Cott, The Bonds of Womanhood: "Woman's Sphere" in New England, 17801835 (New Haven: Yale University Press, 1977) and Barbara Leslie Epstein, The Politics of Domesticity: Women, Evangelism and Temperance in Nineteenth Century American (Middleton, Connecticut: Wesleyan University Press, 1981).
} 
accomplishments in the creation of educational opportunities for women.

Modern day feminists might accuse willard of compromising her principles or of simply "selling out" by attempting to work within the limits established by society. They have suggested that in adopting the argument that there should be a "separate sphere" of influence for women, progressive educational reformers, such as Emma Willard, who chose to develop new opportunities for women within established limits, were little more than "pragmatic feminists," and thus their motives are to be questioned. 3

This accusation fails, once again, to perceive that the "separate sphere" rationale mirrored the early nineteenth century's attempt to find a comfortable compromise between the country's need for teachers, the underlying democratic and egalitarian principles which supported a push for an educated citizenry, and the seemingly undesirable feminist consequences of letting women into the work force. For Willard, the use of the separate sphere rationale was quite simply, for her generation and gender, the best possible compromise. It allowed her to get things done.

3For a discussion of the term "pragmatic feminist" see, Jill K. Conway, "Women Reformers and American Culture, 1870-1930," Journal of Social History 5 (Winter 1971-72): 164-77. See also June Sochen, Movers and Shakers: American Women Thinkers and Activists (New York: Quadrangle Books, The New York Times Book Co., 1973), 7-9. 
In her belief that she had a God-given job to do, Willard's work illustrates the resolution of another intellectual conflict typical of her era: the spiritual vs. secular utility of education. As with many of her countrymen, Willard's Puritan upbringing gave divine sanction to hard work and personal self-sacrifice. "Laboring for the Lord" was consistent with religious scripture, but the conspicuous accumulation of material wealth spawned by the Industrial Revolution was not.

This new type of wealth, created in factories, cities and workhouses, differed greatly from riches God provided in agriculture and the land. But the fact that the young country needed an educated citizenry for its industry caused economic utility to replace religious motivation as the main criterion by which willard and her contemporaries evaluated America's education system.

Philosophically unable to leave Puritanism behind, the country's educational leaders once again needed to effect a compromise. Combining the essence of Calvinist values such as duty, thrift, discipline, and moral virtue, with the skills and labor requirements of the Industrial Revolution in America, reformist educators created a nearly fool-proof mechanism for transferring earlier religious strictures into secular dogma to justify the economic reality of the times. 
The apparent conflict between spiritual morality and the accumulation of worldly goods was solved by an educational system which preached the "rightness" of material prosperity. Locke's right of private property was smoothly combined with the "self-evident truth" that God had blessed the American, democratic way of life and produced a country on the verge of abundance. The schools and textbooks of the time reinforced and magnified this belief, and Willard and her contemporaries rejoiced in the material wealth of America's citizens. Finally, Emma Willard's educational philosophy mirrored the continuing debate among the educational theorists of her day as to the exact process of human understanding. As has been pointed out, her definition of rationality was essentially Lockean--eminently logical and sensory in nature. But while Locke and other Enlightenment thinkers made a case for the dominance of the cognitive domain in human learning, Willard and others could not quite accept this totally antiseptic view. Man, they felt, was not simply a machine--a body without a soul. He learned through spiritual experience as well.

As discussed earlier in this paper, the First and Second Great Awakenings were America's emotional reaction to the sterility of Enlightenment rationality. In the realm of educational theory, the door was opened by Jonathan Edwards and others to the importance of the affective domain in the 
process of human understanding. Man, they suggested, learned not only by analyzing sensory data but also through the emotions. Human feelings were equally important in the process of acquiring knowledge. Emma Willard agreed. In her belief that there was value in divine revelation, Christian benevolence and free-will in the process of human learning, Willard was a partner in this attempted synthesis between affective and cognitive understanding.

\section{Emma Willard's Enduring Legacy}

Any final assessment of Emma Willard's educational philosophy must include the fact that her importance lies not only in the ways in which she was different from her contemporaries but also how she was similar. In the compromises her thoughts on education made, willard helped to provide an intellectual and emotional bridge between the eighteenth and nineteenth century. Her conflicts and inconsistencies were those of a generation which had left behind much that was certain. They faced a modern new world.

In Henry Barnard's Memoirs of Teachers, Educators, and Promoters and Benefactors of Education, the entry for Emma Willard reads as follows,

The selection of Mrs. Emma Willard to occupy a place in this gallery of eminent American Teachers, was not, so much because of her accomplished work, immense as it has been; not because she had by unsurpassed energy established the first scientific female seminary; nor because, as an author, a million of her books were 
circulated; nor because she has published various

addresses on the subject of education, . . nor because she enlisted wide discussion and general interest, by the results of investigation in physiology; nor because she has done much disinterested work for the improvement of the public schools; nor because she initiated in her own Seminary a system for the special education of teachers; but because she is preeminently a REPRESENTATIVE WOMAN, who suitably typifies the great movement of the nineteenth century for the elevation of women. . . .4

These seems little doubt that Willard's contemporaries saw her as a "representative woman" of the nineteenth century. In this "representative" stance we find the enduring quality of Emma Willard's philosophy of education.

\footnotetext{
${ }^{4}$ Henry Fowler, "Educational Services of Mrs. Emma Willard," Henry Barnard, ed., Memoirs of Teachers, Educators and Promoters and Benefactors of Education, Literature and Science (New York: F.C. Brownell, 1861; reprint, New York: Arno Press and the New York Times, 1969), 167.
} 


\title{
SELECTED BIBLIOGRAPHY
}

\author{
EMMA WILLARD AND THE TROY FEMALE SEMINARY
}

Books and Pamphlets:

Brainerd, Ezra. Life and Work in Middlebury, Verment, of Emma Willard. New York: Evening Post Job Printing House, 1893.

Coit, Rev. Tomas Winthrop. A Sermon in Reference to the Death of Mrs. Emma Willard. Troy: W. H. Young and Blake, 1870 .

Fairbanks, Mrs. A. W., ed. Emma Willard and Her Pupils, or Eifty Years of the Troy Female Seminary, 1822-72. New York: Privately Printed, 1898.

Fowler, Henry. "The Educational Services of Mrs. Emma willard." In Memoirs of Teachers, Educators, and prometers and Benefactors of Education, Literature, and Science, ed. Henry Barnard, 125-67. New York: F. C. Brownell, 1861; reprint, New York: Arno Press and the New York Times, 1969.

Goodsell, Willystine, ed. "Emma Willard." Chap. in Pioneers of Women's Education. New York: McGraw Hill, 1931.

Hale, Sarah Josepha. "Emma Willard." Chap. in Women's Record or sketches of AII Distinguished Women from creation to A.D. 1854: Arranged in Four Eras with Selections from Female Writers of Every Age. New York: Harper and Bros., 1855; reprint, New York: Source Book Press, 1970.

James, Edward T. ed., Notable American Women, 1607-1950; A Biographical Dictionary. Vol. 3, "Emma Hart Willard," by Frederick Rudolph. Cambridge: Belknap Press, 1971.

Lord, John. The Life of Emma Willard. New York: D. Appleton and Co., 1873. 
Lutz, Alma. Emma Willard, Daughter of Demecracy. Boston: Houghton Mifflin, 1929.

- Emma Willard; Pioneer Educator of American Women. Boston: Beacon Press, 1964.

North, Catharine M. History of Berlin, Connecticut. Rearranged and Edited with Foreward by Adolph Burnett Benson. New Haven: The Tuttle, Morehouse and Taylor Company, 1916.

Norton, Alice. "Mrs. Emma Hart Willard, 1787-1870; An Historical Sketch Prepared by Miss Alice Norton, Regent, and Read at a Meeting of the Emma Willard Chapter D.A.R., Berlin, Conn. November, 1904." n.p. 1904.

The Reviewer of Mrs. Emma Willard Reviewed. Philadelphia: C. Sherman and Company [1839].

Sweet, Stephen R. "Mrs. Willard on Normal Institutes." Chap. in Teachers' Institutes, Temporary Normal Schools: Their erigins and Progress, Including a synopsis of Their Proceedings, and Practical Hints to Teachers. Syracuse: Barnes, Smith and Cooper, Printers, 1848.

Willard, Mrs. John H. "A Memorial of the Late Mrs. Emma Willard." In Proceedings of the Seventh Anniversary of the University Convocation of the State of New York, August 2-4, 1870. Albany: The Argus Company Printers, 1871 .

Willson, Marcius. Reply to Mrs. Willard's Appeal. New York: Mark H. Newman and Company, 1847.

Journal Articles:

Calhoun, Daniel H. "Eyes for the Jacksonian World: William C. Woodbridge and Emma Willard." Journal of the Early Republic 4 (Fall 1984): 1-26.

Fowler, Henry. "The Educational Services of Mrs. Emma Willard." American Journal of Education 6 (March 1859): 125-68. Microfilm.

Griffiths, Mary Ellen. "Emma Willard." Connecticut Teacher (December 1946): 60-79. 
Holden, James Austin. "Emma Willard, A Sketch and a Letter." Educational Review 2 (April 1916): 387-96.

Lambert, Pierre D. "Women in Education: The Known, The
Forgotten and the (Spring 1983): 93-112. Vitae Scholasticae 2

Medler, Keith. "Mask of Oppression: The Female Seminary Movement in the United States." New York History 55
(July 1974): 261-79.

Meyer, Margaret R. "Emma Willard and the New York State Teachers' Institutes of 1845." Journal of Educational
Research 44 (May 1951): 697-701.

Nelson, Murray A. "Emma Willard: Pioneer of Social Science (Fall 1987): $245-56$ and Research in Secial Education 15

"Review of Willard's of America." Americary of the United States or Republic 1855) : 282.

Scott, Anne Firor. "The Ever Widening Circle: The Diffusion
From the Troy Fema Education Ouarterly (Spring 1979): 3-25.

Journal "What, Then, is the American: This New Woman?" Journal of American History 65 (December 1978): 679-703.

"The Troy Female Seminary." American Ladies Magazine 6 (June 1833) : 402-5; 8 (August 1835): 700-11.

Swift, Samuel. History of the Town of Middlebury in the County of Addison, Vermont. Middlebury: n.p., 1859.

Magazines:

Bartlett, Ellen Strong. "Emma Willard, a Pioneer of 1902): 555-71.

Godey's Ladies Magazine. 56 (October 1860): 368-69. 
Newspaper Articles:

"Women as Factors in American History; Emma Willard." The National Republican, 30 April 1921, 8.

New York Mirror. 1833.

"Emma Willard School Centenary Alumnae Day." Troy Record, 6 October, 1914 .

Published Proceedings and State Documents:

Willard, Mrs. John H. "A Memorial to the Late Mrs. Emma Willard." In Proceedings of the Seventh Anniversary University Convocation of the State of New York, held August $2 \mathrm{~d}, 3 \mathrm{~d}$, and $4 \mathrm{th}, 1870$. Albany: The Argus Company, Printers, 1871.

- "A Sketch of the History of the Troy Female Seminary." In Proceedings of the Thirteenth Anniversary University Convocation of the State of New York, held July 12th, 13th and 14th, 1876. Albany: The Argus Company, Printers, 1876.

Unpublished Materials:

Meyer, Margaret R. "Preceptress of a Female Seminary; Consisting of a Document, 2 Letters and A Calendar of Emma Willard Papers in Russell Sage College Library." Troy, 1947. Typescript. Emma Willard School Archives, Troy, New York.

Nelson, Murray R. "Emma Willard: Pioneer in Social Studies Education." A paper presented at the Sixty-ninth Annual Meeting of the American Educational Research Association. Chicago: 31 March - 4 April, 1985. Textfiche.

Scott, Anne Firor. "Emma Willard: Eeminist." Commencement address, Emma Willard School, Troy, New York, 10 May 1978. Typescript copy Emma Willard School Archives, Troy, New York.

Willard, Dr. John. "Testimony of Dr. John Willard concerning alleged pirating by William C. Woodbridge, of Mrs. Willard's ideas for a geography textbook, April 26, 1825." Typescript copy. Emma Willard School Archives, Troy, New York. 
School Catalogues:

Catalogues of the officers and Pupils of the Troy Female Seminary, 1822 through 1871. Emma Willard School Archives, Troy, New York.

WRITINGS OF EMMA WILLARD

Published:

Willard, Emma. Abridged History of the United States: or Republic of America. New York: A. S. Barnes and Co., 1852 .

- Abridged History of the United States; or Republic ef America. New York: A. S. Barnes and Co., 1868.

- "Address on the Time and Teaching of Little Children." New York Teacher 2 (1854), 108-11, 136-41, 202-5.

- Advancement of Female Education, or a Series of Addresses in Favor of Establishing at Athens, in Greece, a Female Seminary, Especially Designed to Instruct Female Teachers. Troy: Normal Tuttle, 1833.

- An Address to the Public: Particularly to the Members of the Legislature of New York, Proposing a Plan for Improving Female Education. Middlebury: J. W. Copeland, 1819.

- An Appeal against Wrong and Injury. New York: A. S. Barnes and Co., 1847.

- Ancient Geography as connected with Chronology and Preparatory to the Study of Ancient History: Accompanied with an Atlas. Hartford: O. D. Cooke, 1829.

- Astronography, or Astronomical Geography, with the Use of the Globes. Troy: Merriam, Moore and Co., 1854.

- Fulfillment of a Promise, by Which Poems by Emma Willard are Published, and Affectionately Inscribed to Her Past and Present Pupils. New York: White, Gallaher and White, 1831. 
- Geography for Beginners: or the Instructor's

Assistant, in Giving Eirst Lessons from Maps, in the Style of Familiar Conversation. Hartford: Oliver D. Cooke and Co., 1826.

- Guide to the Temple of Time and Universal History

for Schools. New York: A. S. Barnes and Co., 1850.

- History of the United States or Republic of America, Exhibited in Connexion with Its Chronology and Pregressive Geography, by a Series of Maps. New York: White, Gallaher and White, 1830.

- Journal and Letters from Erance and Great Britain. Troy: N. Tuttle, 1833.

- Late American History: Containing a Full Account of the courage, Conduct, and success of John C. Fremont, by Which, through Many Hardships and Sufferings He Became the Explorer and Hero of California. New York: A. S. Barnes and Co., 1856.

- Last Leaves of American History: Comprising a Separate History of California. New York: A. S. Barnes and Co., 1853.

- "Letter." In The Trojan Sketch Book. Troy: Young and Hart, 1846. Typescript. Emma Willard School Archives, Troy, New York.

- Letter Addressed as a Circular to the Members of the Willard Association, for the Mutual Improvement of Eemale Teachers. Troy: Elias Gates, 1838.

"Letter from Mrs. Emma Willard, on a 'Proposed Plan of a Female Association to Improve Schools", "in "Female Common School Association in the East District of Kensington, Connecticut." American Journal of Education 15 (November 1865): 612-16.

- Letter to Dupont de l'Eure on the Political Position of Women. Albany: Joel Munsell, 1848 . Typescript. Emma Willard School Archives, Troy, New York. 
- Memorial of Emma Willard, Principal of Troy Female Seminary. To the Honorable the Legislature of the state of New York. New York State Assembly Document No. 41 (25 January, 1823): 1-10.

- Morals for the Young; or, Good Principles Instilling Wisdom. New York: A. S. Barnes and Co., 1857 .

- "Proposed Plan of Improvement." Connecticut common School Journal 2 (April 1840): 242-44.

- "Public Examination of Summer Schools." connecticut common School Journal 3 (December 1840): 2931 .

- Respiration and Its Effects: Most Especially in Relation to Asiatic Cholera and Other Sinking Diseases. New York: Huntington and Savage, 1849.

- "The Relation of Females and Mothers Especially to the Cause of the Common School Improvement." connecticut Common School Journal 5 (March 1842): 64-66.

- de Saussure, Madame Necker. Progressive Education commencing with the Infant. Trans. with notes and appendix by Emma Willard and Almira Iincoln Phelps. Boston: William D. Ticknor, 1835.

- "The Schoolmistress, Article 1: Introductory." New York Teacher 3 (February 1855): 252.

- "The Schoolmistress, Article 2." New York Teacher 3 (March 1833): 318-21.

- "The Schoolmistress, Article Three: The

Schoolhouse." New York Teacher 3 (April 1855): 29-31.

- "The Schoolmistress, Article Fourth: Extract from a letter to the Rev. S. G. Bragg, of Georgia, dated April 23, 1855." New York Teacher (May 1855): 68-69.

- "The Schoolmistress, Article Fifth." New York Teacher 3 (June 1855): 138-40.

- Treatise on the Motive Powers which Produce the Circulation of the Blood. New York: Wiley and Putnam, 1844 . 
Willard, Emma and William C. Woodbridge. Universal Geography. 4th ed., Hartford: Oliver D. Cooke and Co., 1831 .

Willard, Emma. Universal History in Perspective. 7th ed. New York: A. S. Barnes and Co., 1849.

- Universal History in Perspective. 12th ed. New York: A. S. Barnes and Co., 1855.
- "Universal Terms-Dispute Concerning Them and Their Causes." American Journal of Science and Arts 23 (July 1832) : $18-28$.

- Via Media: A Peaceful and Permanent settlement of the Slavery Question. Washington: Henry Polkinhorn, Printer, 1862 .

Unpublished Materials:

Willard, Emma Hart to her parents, August 1807. Typescript copy. Emma Willard School Archives, Troy, New York.

Willard, Emma to Professor Cogswell, Hanford, Connecticut, 10 January, 1842. Xerox of original. Emma Willard School Archives, Troy, New York.

Willard, Emma to stepson, Benjamin Franklin Willard, 1821. Typescript copy. Emma Willard School Archives, Troy, New York.

Selections from the Diary of Emma Willard, 1 January 1845 17 December, 1845. Typescript with annotations. Emma Willard School Archives, Troy, New York.

Handwritten margin notes by Emma Willard. Typescript copy of Plan for Improving Female Education. n. d., Emma Willard School Archives, Troy, New York.

GENERAL WORKS ON EDUCATION

Books:

Bailyn, Bernard. Education and the Forming of American Society: Needs and Opportunities for Study. New York: Vintage Books, 1960. 
Binder, Frederick M. The Age of the Common School, 18301865. New York: John Wiley and Sons, 1974.

Blinderman, Abraham. American Writers on Education Before 1865. Boston: Twayne Publishing, 1975.

Button, A. Warren and Eugene F. Provenzo Jr. A History of Education and Culture in America. New Jersey: Prentice Hall, 1989.

Cremin, Lawrence A. American Education, The colonial Experience, 1607-1783. New York: Harper and Row, 1970.

- American Education, The National Experience, 17831876. New York: Harper and Row, 1980.

Cubberley, Ellwood P. Public Education in the United States: A Study and Interpretation of American Educational

History. Cambridge: Houghton Mifflin, 1947.

Dexter, F. B. Biegraphical Sketches of the Graduates of Yale College with Annals of the college History, 1885-1912. Vol. 5, New Haven: Yale Press.

Hansen, Allen Oscar. Liberalism and American Education in the Eighteenth Century. New York: Octagon Books, 1977.

Herbst, Jurgen, ed. The History of American Education. Goldentree Bibliographies in American History, Northbrook, Illinois: AHM Publishing Corporation, 1973.

Katz, Michael B. "The Origins of Public Education: A Reassessment." In The Social History of American Education, ed. B. Edward McClellan and William J. Reese, 110-38. Chicago: University of Illinois Press, 1988.

Noble, Stuart G. A History of American Education. New York: Farrar and Rinehart, 1938.

Rush, Welter. American Writings on Popular Education, The Nineteenth Century. Indianapolis: Bobbs-Merrill Company, 1971.

Spring, Joel. The American Scheol: 1642-1985. Varieties of Historical Interpretation of the Foundations and Development of American Education. New York: Longman, 1986. 
- Education the Worker-Citizen, The Social, Economic and Political Foundations of Education. New York:

Longman, 1980.

Journals:

American Journal of Education. August 1855 - December 1882.

Connecticut Common School Journal. 1838 - 1842.

Connecticut Common School Journal and Annals of Education. September 1851 - December 1856; January 1857 - December 1866 .

WOMEN'S HISTORY AND EDUCATION

Books :

Beecher, Catharine. A Treatise on Domestic Economy. Rev. ed., Boston: Thomas A. Webb and Company, 1842.

Boas, Louise S. Women's Education Begins: The Rise of Women's Colleges. Norton, Massachusetts: Weaton College Press, 1935; reprint, American Education: People and Ideas Series, New York: Arno Press, 1971.

Bolzau, Emma Lydia. Almira Lincoln Phelps: Her Life and Work. Philadelphia: Science Press Company, 1936.

Brackett, Anne A. The Education of American Girls in the South Prior to 1860. New York: Neale Publishing, 1909; reprint, New York: Zinger Publishing, 1976.

Browne, Alice. The Eighteenth Century Eeminist Mind. Detroit: Wayne State University Press, 1987.

Conrad, Susan Phinney. Perish the Thought: Intellectual Women in Romantic America 1830-1860. New York: Oxford University Press, 1976.

Cott, Nancy F. The Bonds of Womanhood: "Woman's Sphere" in New England, 1780-1835. New Haven: Yale University Press, 1977. 
Dexter, Elizabeth Anthony. Career Women of America, 17761840. Francestown, New Hampshire: Marshall-Jones Company, 1950 .

Epstein, Barbara Leslie. The Politics of Domesticity; Women, Evangelism and Temperance in Nineteenth Century America. Middletown, Connecticut: Wesleyan University Press, 1981.

Goodsell, Willystine. The Education of Women; Its Social Background and Its Problems. New York: Macmillan Company, 1923.

Hill, Bridget, ed. The First English Feminist: Reflections Upon Marriage and other Writings by Mary Astell. London: St. Martin's Press, 1986.

Jex-Blake, Sophia. A Visit to Some American Schools and Colleges. London: MacMillan and Company, 1867; reprint, Westport, Connecticut: Hyperion Press, 1976.

Kerber, Iinda K. "Daughters of Columbia: Educating women for the Republic, 1787-1805." Chap. in Jean E. Freidman and William G. Slade. Our American Sisters: Women in American Life and Thought. Boston: Allyn and Bacon, Inc., 1973.

- The Impact of Women on American Education. Washington, D.C.: United States Department of Education, 1983.

- Women of the Republic: Intellect and Ideology in Revolutionary America. Institute of Early American History and Culture. Williamsburg: University of North Carolina Press, 1980.

Kinnard, Cynthia D. Anti-Feminism in American Thought: An Annotated Bibliography. Boston: G. K. Hall: 1986.

Kuhn, Anne L. The Mother's Role in Childhood Education: New England Concepts, 1830-1860. New Haven: Yale University Press, 1947.

Lerner, Gerda. The Woman in American History. Menlo Park, California: Addison-Wesley Publishing Company, 1971.

Martin, Jane Roland. Reclaiming a Conversation: The Ideal of the Educated Woman. New Haven: Yale University Press, 1985 . 
Orton, James, ed. The Liberal Education of Women: The Demand and the Method-current Thought in America and England. New York: A. S. Barnes and Company, 1870.

Phelps, Almira Lincoln. The Educator, or Hours with my Pupils. New York: A. S. Barnes and Company, 1870. - The Female Student or Lectures to Young Ladies on Female Education for the use of Mothers, Teachers and Pupils. New York: Leavitt, Lord and Company, 1836.

Sklar, Kathryn Kish. Catharine Beecher, A Study in American Domesticity. New Haven: Yale University Press, 1973.

Sochen, June. Movers and Shakers: American Women Thinkers and Activists. New York: Quadrangle Books, The New York iimes Book Company, 1973.

Solomon, Barbara Miller. In the Company of Educated Women: $A$ History of Women and Higher Education in America. New Haven: Yale University Press, 1985.

Stock, Phyllis. Better Than Rubies: A History of Women's Education. New York: Capricorn Books, G. P. Putnam's Sons, 1978.

Taylor, James Monroe. Before Vassar Opened: a Contribution to the History of the Higher Education of Women in America. Boston: Houghton Mifflin Company, 1914.

Thompson, Eleanor $W$. Education for Ladies, 1830-1860: Ideas on Education in Magazines for Women. New York: Kings Crown Press, 1947.

Woody, Thomas. A History of Women's Education in the United States. 2 Vol., New York: The Science Press, 1929.

Journal Articles:

Bloch, Ruth H. "American Feminism, Ideals in Transition: The Rise of the Moral Mother, 1785-1815." Eeminist Studies 4 (June 1978): 100-26.

Boylan, Anne M. "Evangelical Womanhood in the Nineteenth Century: The Role of Women in Sunday Schools." Eeminist Studies 4 (October 1978): 62-80. 
Bunkle, Phillida. "Sentimental Womanhood and Domestic Education, 1830-1870." History of Education Quarterly 14 (Spring 1974): 13-31.

Conway, Jill K. "Perspectives on the History of Women's Education in the United States." History of Education Quarterly 14 (Spring 1974): 1-11.

- "Women Reformers and American Culture, 1870-1930," Journal of Social History 5 (Winter 1971-72): 164-77.

Cott, Nancy F. "Young Women in the Second Great Awakening in New England." Feminist Studies 3 (Fall 1975): 15-29.

Kerber, Iinda K. "The Republican Mother: Women and the Enlightenment - An American Perspective." American Quarterly 28 (Summer 1976): 187-205.

Lebranbaum, Miriam. "Mistresses of Orthodoxy: Education in the Lives and Writings of Late Eighteenth Century Women Writers." Proceedings of the American Philosophical Society 121 (August 1977): 281-301.

Melder, Keith. "Women's Higher Calling: The Teaching Profession in America, 1800-1850." American Studies 13 (Fall 1972): 19-32.

Miller, P. J. "Women's Education, 'Self-Improvement', and Social Mobility." British Journal of Educational Studies 20 (October 1972): 303-14.

Monaghan, E. Jennifer. "Literacy, Instruction and Gender in Colonial New England." American Quarterly 40 (March 1988) : $18-41$.

Reynolds, David S. "The Feminization Controversy: Sexual Stereotypes and the Paradoxes of Piety in Nineteenth Century America." New England Quarterly 53 (March 1980): $96-106$.

Riley, Glenda Gates. "The Origins of the Argument for the Improvement in Female Education." History of Education ouarterly 9 (Winter 1969): 455-70.

Ryan, Mary P. "A Woman's Awakening: Evangelical Religion and the Families of Utica, New York, 1800-1840." American Quarterly 30 (Winter 1978): 602-23. 
Scott, Anne Firor. "Women's Perspective on the Patriarchy of the 1840s." Journal of American History 61 (June 1964): $52-64$.

Smith-Rosenberg, Carroll. "The Hysterical Woman: Sex Roles and Role Conflict in Nineteenth Century America." Social Research 39 (Winter 1972): 652-78.

Straub, Jean. "Benjamin Rush's Views on Women's Education." Pennsylvania History 34 (1967): 47-57.

Welter, Barbara. "Anti-Intellectualism and the American Woman, 1800-1860." Mid-America 18 (October 1966): 25870 .

- "She Hath Done What She Could: Protestant Women's Missionary Careers in Nineteenth Century America." American Quarterly 30 (Winter 1978): 624-38.

- "The Cult of True Womanhood: 1820-1860." American Quarterly 18 (Summer: 1966): 151-74.

Magazines:

Sigourney, Lydia. "The Little Hand." Parent's Magazine 1:2, December $1840,71$.

Doctoral Dissertations:

Brickley, Lynn Templeton. "Sarah Pierce's Litchfield Academy, 1792-1833." Ph.D. diss., Harvard University, 1985 .

Fowler, Sandra Brandmark. "The Character of the Woman Teacher During her Emergence as a Full Time Professional in Nineteenth Century America: Stereotype vs. Personal Histories." Ph.D. diss., Boston University, 1985.

Hodges, Sushmita. "Women and Education: Social Feminism and Intellectual Emancipation in England and America, 17601860." Ph.D. diss., Ball State, 1989.

Kasbekar, Veena P. "Power Over Themselves: The Controversy About Female Education in England, 1660-1820." Ph.D., diss., University of Cincinnati, 1980. 
Martusewicz, Rebecca Ann. "The Will to Reason: An Archeology of Womanhood and Education, 1880-1920." Ph.D. diss., University of Rochester, 1988.

Methven, Lily Stewart. "Women Writers on the Education of Women, 1847-1869." Ph.D. diss., University of Washington, 1987 .

Townsend, Lucy Forsyth. "Anna Peck Sill and the Rise of Women's Collegiate Curriculum." Ph.D. diss., Loyola University, 1985.

EDUCATIONAL THEORY, METHOD AND INSTRUCTIONAL DESIGN

Books :

Antczak, Frederick J. Thought and Character: The Rhetoric of Democratic Education. Ames: Iowa State University Press, 1985.

Bloom, Benjamin, ed. Taxonomy of Educational Objectives. New York: Donald McKay, 1964.

Dewey, John. Democracy and Education. New York: The Macmillan Company, 1916.+

Downs, Robert B. Heinrich Pestalozzi, Father of Modern Pedagogy. Boston: Twayne Publishers, 1975.

Elson, Ruth Miller. Guardians of Tradition, American Schoolbooks of the Nineteenth Century. Lincoln: University of Nebraska Press, 1964.

Gutek, Gerald Lee. Pestalozzi and Education. New York: Random House, 1968.

Locke, John. Some Thoughts concerning Education. With Introduction by Peter Gay. New York: Columbia University Press, 1964.

- Some Thoughts concerning Education. With Introduction by F. W. Garforth. London: Heineman, 1964.

Monroe, Will S. A History of the Pestalozzian Movement in the United States. New York: C. W. Bardeen, 1907; reprint, New York: Arno Press, 1947. 
Nietz, John A. The Evolution of American Secondary School Textbooks. Rutland, Vermont: Charles E. Tuttle Company, 1966.

- Old Textbooks. Pittsburgh: University of Pittsburgh Press, 1961.

Saettler, Paul. A History of Instructional Technology. New York: McGraw-Hill, 1968.

Yolton, John W. John Locke and Education. New York: Random House, 1971.

Journals:

"On the Monitorial System of Education." The Southern Review 1 (May 1828): 478-502.

GENERAL WORKS ON AMERICAN AND EUROPEAN HISTORY AND PHILOSOPHY

Books :

Boorstin, Daniel J. The Americans: The Democratic

Experience. New York: Vintage Books, 1974. - The Americans: The National Experience. New York: Vintage Books, 1965.

Chauncey, Charles. Enthusiasm Described and Caution'd

Against. Boston: n.p., 1742 .

- Seasonable Thoughts on the state of Religion in

New England. Boston: n.p., 1743.

Edwards, Jonathan. A Careful and Strict Enquiry into the Modern Prevailing Notions of the Freedom of the Will, Which Is Supposed to be Essential to Moral Agency, Virtue and Vice, Reward and Punishment, Praise and Blame. Edited by Tomas Ramsey. New Haven: Yale University Press, 1957.

- Jonathan Edwards: Representative Selections. Edited by Faust and Johnson. New York: American Book Company, 1935. 
"Treatise Concerning Religious Affections." In The Works of Jonathan Edwards in Eour Volumes. Vol. 1. New York: Leavitt, Trow and Company, 1849.

Flower, Elizabeth and Murray G. Murphey. A History of Philosophy in America. New York: G. P. Putnam and Sons, 1977 .

Garraty, John A. and Peter Gay, eds. The Columbia History of the World. New York: Harper and Row, 1972.

Gay, Peter. The Enlightenment: An Interpretation. Vol. 2, The Science of Freedom. New York: Alfred A. Knopf, 1969 .

Joseph, H. W. B. Knowledge and the Good in Plato's Republic. London: Oxford University Press, 1948.

Locke, John. An Essay Concerning Human Understanding. Edited with a Foreward by Peter H. Nidditch. Oxford: Clarendon Press, 1975.

- The Collected Works of John Locke. London: Thomas Tegg, 1823 .

Lockridge, Kenneth. Literacy in Colonial New England: An Enquiry into the Social context of Literacy in the Early Modern West. New York: Norton, 1974.

Riley, Woodbridge. American Thought From Puritanism to Pragmatism and Beyond. Gloucester: Peter Smith, 1959.

Rudé, George. Europe in the Eighteenth Century: Aristocracy and the Bourgeois Challenge. Cambridge: Harvard University Press, 1972.

Sabine, George H. A Histery of Political Theory. 3rd ed. New York: Holt Rinehart and Winston, 1961.

Sloan, Douglas, ed. The Great American Awakening and American Education; A Documentary History. New York: Teacher's College Press, 1973.

- The Scottish Enlightenment and the American College Ideal. New York: Teacher's College Press, 1971.

Smith, Lacey Baldwin. This Realm of England: 1399 te 1688. Lexington: D. C. Heath and Company, 1988. 
Squadrito, Kathleen M. Locke's Theory of Sensory Knowledge. Washington, D.C.: University Press of America, 1978.

Stannard, David E. The Puritan Way of Death: A Study in Religion, Culture and Social Change. Oxford: Oxford University Press, 1977.

Wagoner, Jennings I., Jr. Thomas Jefferson and the Education of a New Nation. Bloomington: Phi Delta Kappa Educational Foundation, 1976.

Journals:

Ashcraft, Richard and M. M. Goldsmith. "Locke, Revolution Principles, and the Formation of whig Ideology." The Historical Journal 26 (December 1983): 773-800.

Lundberg, David and Henry F. May. "The Enlightened Reader in America." American Quarterly 28 (Summer 1976): 262-93.

Meyer, D. H. "The Uniqueness of the American Enlightenment." American Quarterly 2 (Summer 1976): 165-86. 